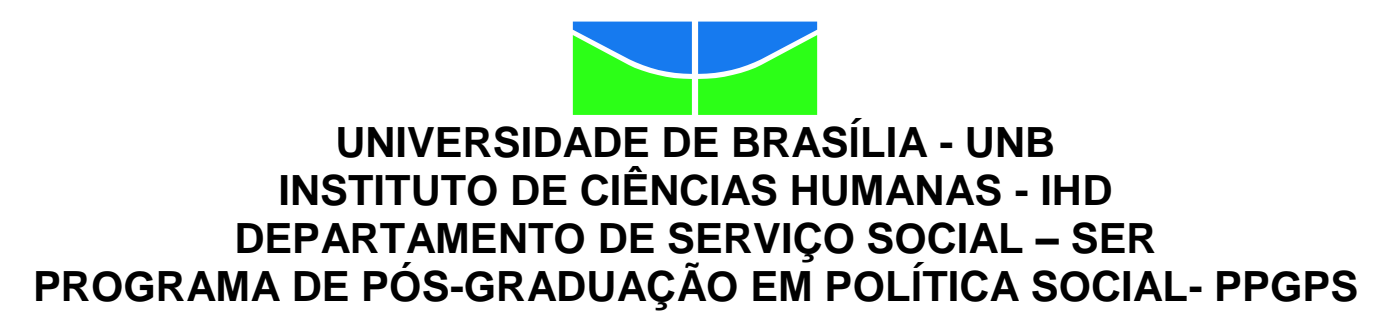

Diego da Conceição Piedade

TENSÕES E SINTONIAS ENTRE ASSISTÊNCIA SOCIAL E TRABALHO NO CAPITALISMO

Uma dialética na qual o direito é mal interpretado 
Diego da Conceição Piedade

\title{
TENSÕES E SINTONIAS ENTRE ASSISTÊNCIA SOCIAL E TRABALHO NO CAPITALISMO \\ Uma dialética na qual o direito é mal interpretado
}

\begin{abstract}
Dissertação de Mestrado apresentada ao Programa de Pós-Graduação em Política Social do Departamento de Serviço Social da Universidade de Brasília/UnB como requisito parcial à obtenção do título de Mestre em Política Social.
\end{abstract}

Orientadora: Prof. ${ }^{\text {a }}$ Dr $\stackrel{\text { a }}{ }$ Potyara A. P. Pereira. 
Ficha catalográfica elaborada automaticamente, com os dados fornecidos pelo(a) autor (a)

PP613t Piedade, Diego da Conceição

TENSÕES E SINTONIAS ENTRE ASSISTÊNCIA SOCIAL E TRABALHO NO CAPITALISMO: Uma dialética na qual o direito é mal interpretado. / Diego da Conceição Piedade; orientador Potyara Amazoneida Pereira Pereira. -- Brasília, 2017. $145 \mathrm{p}$.

Dissertação (Mestrado - Mestrado em Política Social) -- Universidade de Brasília, 2017.

1. Assistência Social. 2. Trabalho. 3. Capitalismo. 4. Direito. 5. Mérito. I. Pereira Pereira, Potyara Amazoneida, orient. II. Título. 


\title{
DIEGO DA CONCEIÇÃO PIEDADE
}

\section{TENSÕES E SINTONIAS ENTRE ASSISTÊNCIA SOCIAL E TRABALHO NO CAPITALISMO \\ Uma dialética na qual o direito é mal interpretado}

\author{
BANCA EXAMINADORA
}
Prof ${ }^{a}$. Drª. Potyara Amazoneida Pereira Pereira Orientadora - (PPGPS/SER/UNB)

Prof. Dr. Reginaldo Guiraldelli Membro Interno - (PPGPS/SER/UNB)

Prof. Dr. Renato Francisco dos Santos Paula Membro Externo - (DSS/ UFG)

Dr. Joselito da Silva Pacheco

Membro externo (Secretaria de Estado de Fazenda e Planejamento/GDF) 
Aos usuários da Assistência Social que, por muitas vezes, são inferiorizados por requererem $e$ acessarem a referida política, seja pelo senso-comum seja por construções teóricas equivocadas. 


\section{AGRADECIMENTOS}

O percurso de construção de uma dissertação é, por muitas vezes solitário; mas, em todas as situações que a precedem, e até mesmo no diálogo que se estabelece com os/as autores/as na sua confecção, há o companheirismo e o incentivo político, teórico e afetuoso de muita gente.

Desta forma, início meus agradecimentos dedicando-os a meus familiares que sempre estiveram prontos para me oferecer segurança e afeto nos momentos difíceis, tanto da minha vida, quanto na Pós-Graduação;

À professora Potyara A. P. Pereira, que é fonte de inspiração, teórica e política e que aceitou o desafio de orientar um desconhecido. Sem dúvidas, com suas orientações, sugestões e correções sempre rápidas e extremamente detalhistas, tive uma qualificada jornada no mestrado e na confecção desta dissertação;

Aos professores que compõem a banca de qualificação e de defesa, Reginaldo Guiraldelli e Renato Paula, pelas correções e ponderações críticas e respeitosas oferecidas;

Aos professores da graduação, companheiros de profissão e luta, Fabricio Fontes, que plantou a semente da continuidade dos estudos desde o programa de iniciação cientifica - PIBIC; Heleni Duarte, que com seu afeto e suporte me ofereceu todas as possibilidades de chegar até aqui; e Jucileide Nascimento, que nunca mediu esforços e incentivo para esta conquista;

A amiga e irmã de coração Kamila Araújo, que me acompanhou e compartilhou o sonho da Pós-Graduação desde a graduação; a Ezilda Barreto, que forneceu suporte no momento de transição de cidade e a Camila Moreira, que fez contribuições e correções que foram decisivas para a submissão do projeto na seleção; 
A todxs xs colegas de mestrado, em especial Rafaela Fernandes (irmã de coração), dando-me sempre motivos para sorrir nos momentos de solidão nesse percurso; Matheus Magalhães, pelas conversas e tentativas de me retirar da monotonia; Blenda Peixoto, por sempre compartilharmos os dilemas das escolhas que fazemos nessa vida acadêmica; Jacqueline Domiense, pelo olhar sempre atento e crítico da realidade; Natalia Caixeta sempre doce e preocupada; Thiago Rezende, sempre com dicas e sugestões teóricas relevantes. Sentirei saudades de vocês todxs!

Agradeço também aos professores e funcionários do Programa de Pósgraduação em Política Social do Departamento de Serviço Social da Universidade de Brasília, em especial a Domingas, que nunca negou uma orientação, principalmente nos momentos de desespero;

Aos funcionários e colegas da moradia de estudantes da pós-graduação, da Universidade de Brasília, o bloco $\mathrm{K}$ da Colina, em especial a Adalberto, Hans, Ludovico, Jessiara, Cristiano, Monica, Daiane e Edivan, que tornaram a estadia em Brasilia-DF menos solitária e mais leve.

À CAPES, por ter financiado minha permanência na Pós-Graduação; sem este apoio dificilmente eu teria concluído o mestrado. 


\section{RESUMO}

A presente dissertação trata das contradições presentes na relação entre o Trabalho e a política de Assistência Social no modo de produção capitalista, que se demonstram sob a forma simultânea de tensão e de sintonia. No centro desse processo está em disputa a concepção teórica e operacional da categoria "Direito". Para a ala liberal da sociedade, essa categoria só pode ser caracterizada e materializada pela via do trabalho assalariado, produtor de mais valia, independentemente de sua condição, o que constitui um non sense. Para estes, qualquer concepção e prática de direitos que destoe dessa perspectiva vai de encontro à ética capitalista do trabalho e à meritocracia. Logo, trabalho assalariado estaria diretamente associado ao sucesso individual por mérito próprio. É nessa perspectiva, que se percebe o intento de negar a política de Assistência Social, como direito do cidadão e dever do Estado, inserindo em seu seio, de forma sutil, mecanismos que sobrepõem o mérito laboral ao direito à proteção contra os abusos do trabalho assalariado. $E$ tais mecanismos respondem pelo retorno do titular do direito (desmercadorizado) à assistência social ao mercado de trabalho, mediante a indução a empregos precários e cursos de profissionalização pontuais e aligeirados. Esses cursos, grosso modo, nascem como uma proposta de “complementação da qualificação dos usuários", mas, a sua verdadeira finalidade é a de subsidiar a criação de "portas de saída" da Assistência Social que fica cada vez mais reduzida a um mero alívio da pobreza. Essa tendência de ativação dos demandantes das políticas sociais para o trabalho não se limita ao território brasileiro, mas constitui um movimento internacional que, sob a lógica liberal do workfare (bemestar em troca de trabalho), acirra as contradições, de fundo estrutural, intrínsecas a essa dinâmica

Palavras-chave: Assistência Social. Trabalho. Capitalismo. Direito. Mérito. 


\begin{abstract}
This dissertation is about the contradictions in the relationship between Labor and Social Assistance policy in the capitalist mode of production, which is demonstrated under a simultaneous form of tension and harmony. At the core of this process, there is the theoretical and operational conception of the "Right" category. For the liberal wing of society, this category can only be characterized and materialized by the wage labor, producer of surplus value, regardless of its condition, which is a non sense. For them, any conception and practice of rights that is dissonant from this perspective agrees and goes to the capitalist ethic of work and meritocracy. Thus, wage labor would be directly associated with individual success on its own merit. It is from this perspective that we can perceive the attempt to deny the Social Assistance policy, as a right of the citizen and duty of the State, inserting in it, subtly, mechanisms that overlap labor merit to the right to protection against abuses of the wage labor. And such mechanisms respond to the return of the right-holder (decommodified) to social assistance to the labor market, by his induction to precarious jobs and occasional and lightened professional courses. These courses, roughly speaking, are created as a proposal of "complementation of the qualification of the users", but their true purpose is to subsidize the creation of "exit doors" of Social Assistance that is increasingly reduced to a mere relief of poverty. This trend of activation of the demanders of social policies for work is not limited to the Brazilian territory, but constitutes an international movement that, under the liberal logic of workfare (wellbeing in exchange for work), aggravates the structural contradictions Intrinsic to this dynamics.
\end{abstract}

Keywords: Social Welfare. Labor. Capitalism. Capitalism. Merit. 


\section{LISTA DE TABELAS}

Tabela 1-BENEFICIOS E VALORES DO PBF 104

Tabela 2- DESTINAÇÃO DE RECURSOS/CALCULO BÁSICO..............................115

Tabela 3-DESTINAÇÃO DE RECURSOS/CALCULO VARIÁVEL...........................115

Tabela 4- RESPONSABILIDADES DOS ENTES FEDERADOS..............................117

\section{LISTA DE FIGURAS}

Figura 1- FLUXO DE ATUAÇÃO DO PROGRAMA..............................................113 


\section{LISTA DE ABREVIATURAS E SIGLAS}

ABEPSS - Associação Brasileira de Pesquisa e Ensino Em Serviço Social

ABRAS - Associação Brasileira de Supermercados

ACESSUAS - Programa de Acesso ao mundo do trabalho

BPC - Benefício de Prestação Continuada da Assistência Social

CBIC - Câmara Brasileira da Indústria da Construção

CFESS- Conselho Federal de Serviço Social

CNAS - Conselho Nacional da Assistência Social

CRAS - Centro de Referência de Assistência Social

CRESS - Conselho Regional de Serviço Social

CREAS - Centro de Referência Especializado de Assistência Social

FAO - Organização das Nações Unidas para a Alimentação e a Agricultura

FHC - Fernando Henrique Cardoso

LBA - Legião Brasileira de Assistência

MDS - Ministério do Desenvolvimento Social e Combate à Fome

MDSA - Ministério do Desenvolvimento Social e Agrário

NOB/SUAS - Norma Operacional Básica do Sistema Único de Assistência Social

PAIF - Programa de Atenção Integral a Família

PBSM - Plano Brasil Sem Miséria

PGRM - Programas de Garantia de Renda Mínima

PRONATEC - Programa Nacional de Acesso ao Ensino Técnico e Emprego

PTRs - Programas de Transferência de Renda

SUAS - Sistema Único de Assistência Social

PNAS - Política Nacional da Assistência Social

PBF - Programa Bolsa Família 


\section{Sumário}

INTRODUÇÃO

Contextualização e delimitação do problema da pesquisa..............................................14

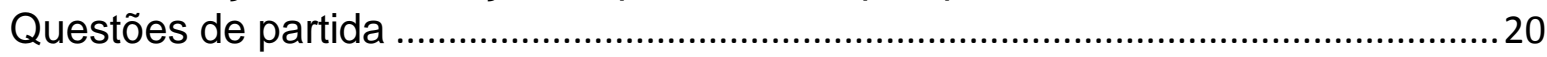

Objeto da pesquisa

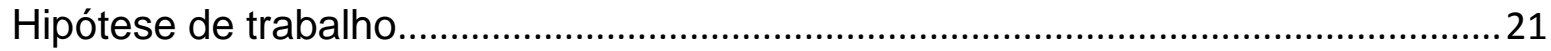

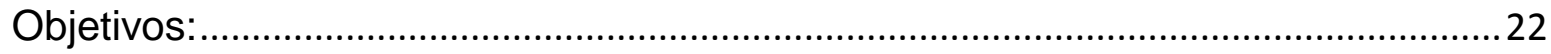

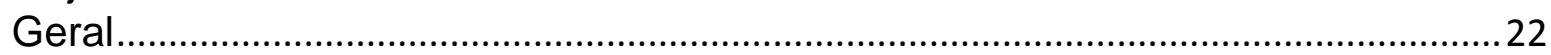

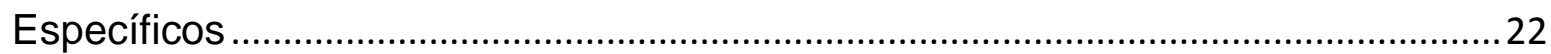

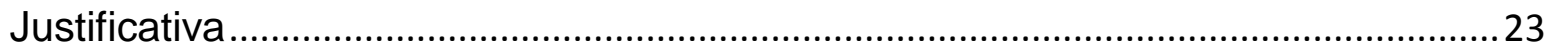

Metodologia

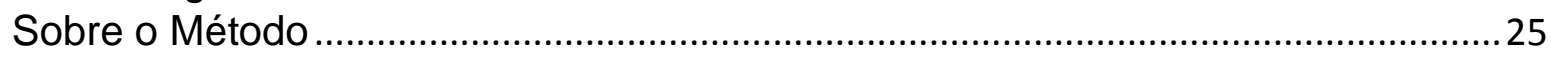

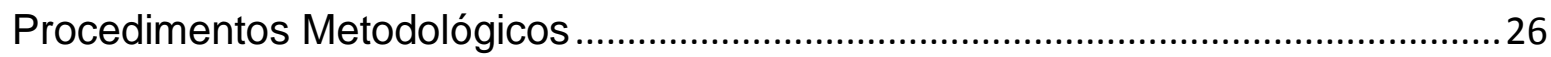

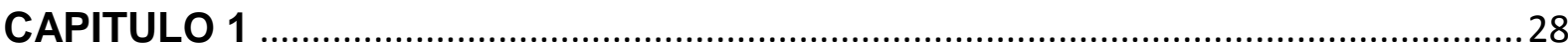

MARCO TÉORICO REFERENCIAL: FUNDAMENTAÇÃO CRÍTICA DO OBJETO DE ESTUDO A PARTIR DAS CATEGORIAS CENTRAIS DE ANÁLISE. ……..........28

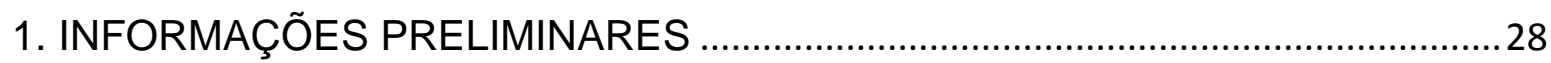

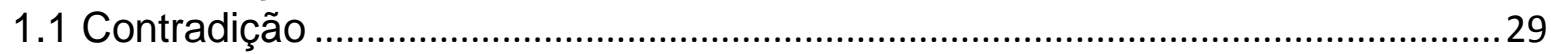

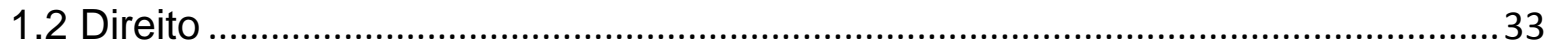

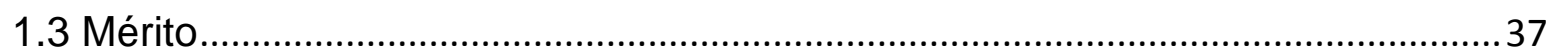

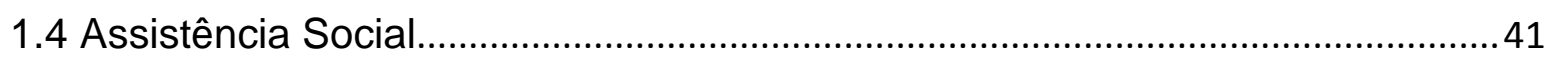

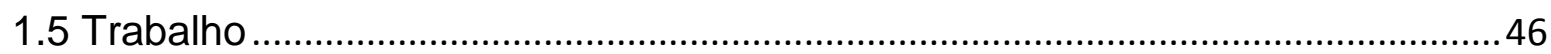

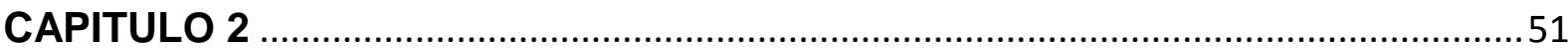

AS RAIZES DO TRABALHO NO BRASIL:ENTRE A PRISÃO ESCRAVISTA À

FALSA LIBERDADE DO TRABALAHO ASSALARIADO ………………............51

$2.1 \mathrm{O}$ trabalho "livre" e desprotegido numa sociedade de raiz escravista.................51

2.2 Breves considerações sobre o trabalho assalariado sob o jugo do capital. .......59

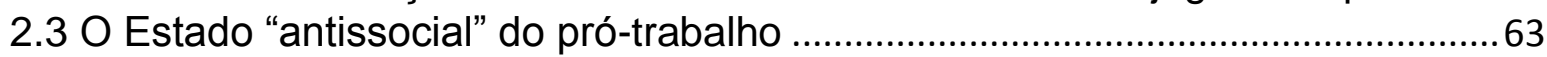

CAPITULO 3

ASSISTÊNCIA SOCIAL E TRABALHO: UMA EQUAÇÃO PERSISTENTE, EMBORA SUTIL, NO CAPITALISMO

3.1 Tensão e Sintonia entre Assistência social e Trabalho assalariado: análise histórico - critica.

3.2 Assistência Social e a lógica do retorno ao Trabalho.

3.3 - Institucionalização da Assistencia Social pós 1988 e a sutil obrigatoriedade do trabalho.

CAPITULO 4

PROGRAMAS BRASILEIROS DE TRANSFERÊNCIA DE RENDA (PTRs) E QUALIFICAÇÃO PARA O MERCADO DE TRABALHOENTRE A FOCALIZAÇÃO E O MÉRITO 
CONSIDERAÇÕES FINAIS

ANEXO A- Resolução CNAS no 33, de 28 de novembro de 2011.

ANEXO B- Resolução CNAS no 18, de 24 de maio de 2012. 


\section{INTRODUÇÃO}

\section{Contextualização e delimitação do problema da pesquisa}

Esta dissertação tem como ponto de partida as percepções mais evidentes acerca da histórica relação entre a assistência social e o trabalho no modo de produção capitalista, constituindo-se, à primeira vista, um processo tensionado por uma possível incompatibilidade entre os direitos à assistência, considerados acomodadores, e os referentes ao trabalho considerados emancipadores; ou pelo domínio poderoso de uma ética capitalista, que associa o trabalho ao mérito de se obter o direito de viver com independência e dignidade, enquanto o direito em si, sem o aval meritocrático, à assistência social, é considerado inadequado.

Daí deriva a tensão criada entre os dois termos do problema aqui colocado neste estudo. Entretanto, outras evidências demonstram que, no mesmo modo de produção capitalista, assistência e trabalho estabeleceram, através dos tempos, relações recíprocas ou sintonizadas. É nessa relação que também se encaixa a história enviesada da construção da assistência social, da noção punitiva e caritativa que conformava sua concepção e práticas. E o trabalho nesse contexto servia tanto para criar uma condição hierárquica de sub-cidadania entre pessoas dotadas de condições laborativas e os demais, leia-se, "inválidos, crianças, velhos", estes merecedores das antigas praticas assistencialistas, e também como punição institucionalizada, nos abrigos e casas de detenção para "vagabundos (os com condições de trabalho mas que não o faziam e migrantes) e menores".

Por toda essa construção histórica marginal da concepção do direito e acesso à política e as imposições do modo de produção vigente, as contradições na assistência social tem assumido protagonismo, por exemplo com o desvio de suas finalidades protetivas - que possibilitariam aos seus usuários, por meio do articulado processo de institucionalização a partir da constituição de 1988, LOAS, PNAS, SUAS e demais, condições, por mínimas que fossem, de não sucumbirem na pobreza extrema e nem se sujeitarem a trabalhos vis - colocando-se a serviço do mercado laboral, geralmente de baixa qualidade; e este mercado, por sua vez, tem se valido da 
assistência social como um complemento político de indução do pobre para o trabalho precário e mal remunerado.

Nesta sintonia, a assistência social ao se aproximar dessa lógica, deixa de possuir status de direito, que estaria vinculado às lutas trabalhistas por proteção contra os abusos do trabalho assalariado degradante, enquanto este, por ser a principal fonte de exploração dos que trabalham, perde igualmente caráter de direito.

Podem-se destacar algumas tendências que contribuem para demonstrar essa funcionalidade da assistência social para o trabalho no modo de produção capitalista. Estas características podem ser verificadas na absorção dessa lógica, por exemplo por via das normativas: i) inserção na LOAS (1993), na parte referente aos objetivos da assistência - "a promoção da integração ao mercado de trabalho"; ii) na PNAS (2004), entre os serviços considerados básicos na assistência social para "a promoção da integração ao mercado de trabalho" estão os "centros de informação e de educação para o trabalho, voltados para jovens e adultos"; iii) e no marco da proteção básica por meio do SUAS, a recorrente recomendação de serviços e programas de "inclusão ou inserção produtiva" que é a face "suavizada" no contexto contemporâneo de incentivo ao retorno ao trabalho.

Verifica-se também nos serviços e programas: iii) a constituição de programas ultrafocalizados, com um viés de alivio da pobreza e com regras e contrapartidas para o acesso e permanência nos referidos programas, como o Programa Bolsa Família, o que foge às características fundamentais de um direito. Neste quesito, há sempre o intento de dificultar a distribuição de benefícios e de estabelecer o vínculo do cidadão com o trabalho como tentativa de tornar obrigatória a sua aceitação de qualquer labor como condição de permanecer assistido; iv) a outra tendência é a recorrente oferta de cursos de qualificação profissional, retirando da proteção básica a característica fundante da oferta de serviços socioassistenciais, individualizando, assim, a responsabilidade do sujeito pela ausência ou não permanência no mercado laboral e isentando de culpa a dinâmica estrutural do modo de produção capitalista que, para se reproduzir, cria artifícios como: a formação do exército de reserva e a mundialização da crise.

O intuito de atribuir à assistência social o lugar de treinamento para o trabalho precário é encarado por alguns estudiosos (ABRAHAMSON, 2009; PEREIRA, 2011; 
JESSOP, 2013) como um processo de retorno da "ativação" dos usuários das políticas sociais para o mercado laboral. Retorno este que potencializa a descaracterização da assistência social como política de seguridade; isso porque, em vez de proteger seus demandantes dos efeitos sociais perversos do sistema do capital, na perspectiva do direito, "funciona como um trampolim, na concepção do Banco Mundial, cuja principal tarefa é ativar os pobres para fora de seu âmbito rumo a sua autossustentação" (PEREIRA, P. 2013 p. 649), vinculando-a à prédica do mérito.

Portanto, a vinculação funcional da assistência social ao trabalho, no modo de produção capitalista, tem como pano de fundo, não a proteção dos trabalhadores contra um modelo de trabalho que extenua e embrutece, mas a intenção de conduzilos e mantê-los nesta lida. Esta é a ética capitalista, que produz um consenso na opinião pública sobre a superioridade do trabalho assalariado em relação a qualquer forma de vida que independa dele, ou se configure desmercadorizada. E mais, gera "uma servidão voluntária" dos trabalhadores e de seus aliados à ideologia de um labor sem alternativas que funciona como uma espécie de crença religiosa em nome do deus progresso. (LAFARGUE, 2005)

Este fato revela que, no capitalismo, tanto o trabalho como a assistência social devem estar a serviço da reprodução do capital devendo, para tanto, desvincularemse do direito social, pois este é incompatível com a lógica da exploração do trabalho e de uma assistência que permanece como um não-lugar nas políticas sociais que, por princípio, deveriam concretizar conquistas cidadãs.

Mesmo assim, é mister considerar a perspectiva contraditória que perpassa a própria categoria direito, sendo esta relacional e que se encontra em permanente processo de afirmação/negação e em disputa. Suas características materiais tendem a ser influenciadas pela prevalência de um conjunto político, que a depender das suas concepções e direcionamentos podem significar mais direito vinculado a afirmação de justiça social, ou mais vinculação com o trabalho assalariado, ou os dois concomitantemente.

O trabalho a que nos referimos também é constituído de contradição e além disso é datado historicamente, isto é, corresponde ao inserido no modo capitalista de produção. Essa delimitação torna-se necessária porque questiona a falsa concepção 
de que há um único tipo de trabalho a ser realizado pela espécie humana ou a de que qualquer trabalho é meritório e dignificante.

Este questionamento exige que compreendamos as mudanças impostas ao trabalho humano pelo capitalismo. Mudanças estas que o afastam da concepção marxiana de uma atividade ontologicamente necessária e teleologicamente planejada, tendo como centralidade a constituição do ser social. Marx (1985), ao destacar a necessidade do trabalho como um fundamento ontológico do ser humano, e da sua relação social, afirma que,

como criador de valores de uso, como trabalho útil, é o trabalho, por isso, uma condição de existência do homem, independente de todas as formas de sociedade, eterna necessidade natural de mediação do metabolismo entre homem e natureza e, portanto, da vida humana (MARX, 1985, p. 50).

Nesta perspectiva, o trabalho desempenharia papel vital para a socialização do homem, assim como teria a propriedade de produzir os processos de manutenção da vida social, de acordo com a máxima: "de cada um segundo a sua capacidade e a cada um de acordo com a sua necessidade" (MARX, 2012, p.33). E isso difere, substancialmente, da percepção capitalista, que subordina o trabalho a uma divisão social e técnica hierárquica e pautada na dicotomia manual x intelectual.

O trabalho, no capitalismo, apesar de não perder sua centralidade, deixa de ter caráter humanizador, para se transformar em um fator de produção de valores de troca e de negociações mercantilizadas. E os que dependem dessa atividade, perdem a autonomia na condução desse trabalho, ou seja, "o trabalhador baixa à condição de mercadoria, e à de mais miserável mercadoria" (MARX, 2004, p.79)

Dessa feita, o trabalho no modo de produção capitalista pelo seu estágio avançado de degradação da vida, convive ao mesmo tempo com seu caráter estranhado mas necessário, e se afasta cada vez mais da dimensão de um direito social de cidadania, ao contrário, tem se tornado num mecanismo vil de tortura do trabalhador, na medida em que o escraviza, retirando-Ihe todo o tempo livre; o aliena dos meios de produção; e o condiciona ao acesso a uma pequena parte dos bens produzidos, sob a forma de um salário extremamente incompatível com a riqueza coletivamente gerada. A esse respeito, afirma Marx (2004) que, 
o trabalhador se torna tanto mais pobre quanto mais riqueza produz, quanto mais a sua produção aumenta em poder e extensão. $O$ trabalhador se torna uma mercadoria tão mais barata quanto mais mercadoria cria. Com a valorização do mundo das coisas aumenta em proporção direta a desvalorização do mundo dos homens. O trabalho não produz somente mercadorias; ele produz a si mesmo e ao trabalhador como uma mercadoria, e isto em medida em que produz, de fato, mercadorias em geral (p. 80).

É em meio a essa trama que se processa a exploração da mão de obra, de um lado, e o acúmulo de riqueza de outro lado, indicando claramente que, "o crescimento capitalista depende essencialmente da exploração do trabalho assalariado" (JESSOP, 2013, p.265). Essa exploração tem como pressuposto a subjugação do tempo livre dos trabalhadores, ampliando e extenuando o tempo na produção de mercadorias.

Foi esse tipo de trabalho, cujo nome derivou de "tripaliare, originário de tripalium, instrumento de tortura, momento de punição e sofrimento" (ANTUNES, 2005 , p. 137) e retirou todo o tempo que os trabalhadores teriam para a construção cultural e intelectual, tempo este que se tornou condenado e amaldiçoado, por ser construtor de um "perfil" de vagabundagem e do ócio. Não foi à toa que Weber (2013), em sua "Ética protestante e o espírito do capitalismo" exaltou o trabalho e abominou o tempo livre, nos seguintes termos:

lembra-te que tempo é dinheiro. Aquele que pode receber dez xelins por dia de trabalho, e que perambula ociosamente, ou fica desocupado metade do dia, embora gaste apenas seis pence durante sua diversão ou em sua mândria, não deve contabilizar esta como sua única despesa; ele despendeu, ou, antes, jogou fora, cinco xelins a mais [...] (p. 52).

Por essa perspectiva, o tempo livre não contribuiria para uma suposta "credibilidade" do trabalhador perante seus credores e, na conjuntura atual, não seria visto com olhos cordiais pela sociedade.

Diferente dessa visão, Lafargue (2005) demonstra como o trabalho contribui para a ausência de qualidade de vida dos indivíduos, que deveria ser fundamentada no culto às artes e no domínio do intelecto. Suas análises, como já mencionado, afirmam que o culto ou o "amor" ao trabalho tem escravizado os indivíduos e a sociedade, que seguem essa ética até o findar das suas forças e que, "na sociedade 
capitalista, o trabalho é a causa de toda a degenerescência intelectual, de toda deformação orgânica" (p. 7).

É por esse prisma que se consolida a perspectiva de um bem-estar individualista pautado em uma estrutura ideológico-prática liberal. Segundo Behring e Boschetti (2011),

\begin{abstract}
Para os liberais, cada indivíduo deve buscar o bem-estar para si e sua família por meio da venda de sua força de trabalho no mercado. Assim, não cabe ao Estado garantir bens e serviços públicos para todos. Nessa perspectiva, cada um, individualmente, deve garantir seu bem-estar, o que levaria todos os indivíduos a atingir uma situação de bem-estar. Tal princípio se funda em outro - a liberdade em detrimento da igualdade (p. 62).
\end{abstract}

Soma-se a essas condições, as características próprias da formação do capitalismo e do trabalho no Brasil. É preciso repertoriar que o caráter colonial e patrimonialista do Estado brasileiro, fundado na hereditariedade de privilégios dos brancos, bem como na exploração do trabalho negro escravizado, funcionaram como um "rolo de moer" gente, ceifando a vida de muitos e marginalizando a inserção nas relações sociais de produção os que sobraram.

A passagem do modo de trabalho escravo para o de "livre" concorrência sentenciou os antigos agentes do trabalho, os negros, ao perecimento, antes, a chibata como forma de força-los e puni-los para trabalhar, agora a "liberdade" sem qualquer forma de reparação-proteção, que os forçava a retornar para vender precariamente sua força de trabalho.

Essa conjuntura marginal se perpetua até o cenário contemporâneo, haja vista a prevalência da mão de obra negra nos trabalhos considerados de mais baixa escolarização e de precarização, e também no acesso a programas sociais de transferência de renda.

Feita essa incursão, podemos levantar a assertiva de que, a assistência social, ao ser elevada à condição de direito não contributivo no âmbito da Seguridade Social, padece pela sua possibilidade de não ser mais uma reprodutora da ética capitalista do trabalho, que não aceita proteções sociais sem contrapartidas, especialmente quando voltadas para os segmentos sociais mais pauperizados da sociedade. Isso 
pode nos indicar caminhos para compreender a sua transformação em instrumento de ativação dos pobres para o trabalho à custa do seu compromisso com a justiça social.

\section{Questões de partida}

Com base no problema da pesquisa exposto e visando a delimitação do objeto de análise desta dissertação, foram formuladas as seguintes questões que serviram de ponto de partida e de fio condutor para a investigação:

$>$ Em que medida a contradição contida na relação de sintonia e tensão entre assistência social e trabalho, no capitalismo, contribui para a descaracterização do estatuto do direito em ambos os componentes dessa relação?

> Por que, no capitalismo, o trabalho assalariado é o lugar do mérito que confere dignidade a quem dele participa, identificando-se muitas vezes com o principal direito do cidadão, ao passo que a assistência social é o lugar do demérito, em que pese o seu intento de proteger o cidadão dos abusos desse trabalho?

> Como explicar a funcionalidade da assistência social às atuais estratégias de ativação de seus demandantes para o trabalho assalariado que, em princípio, a condena?

\section{Objeto da pesquisa}

Constituiu objeto de estudo desta dissertação a especificidade da relação de antagonismo e reciprocidade entre a assistência social e o trabalho, no modo de produção capitalista, na qual a ascendência do mérito sobre o direito implica desvirtuamento deste.

No âmbito deste objeto a nossa unidade empírica de análise foi constituído por dois programas pertencentes à proteção social básica da política de assistência social brasileira, quais sejam: o Programa ACESSUAS - Trabalho e o Programa Bolsa Família, por entendermos que eles se inserem no processo contraditório de tensão e sintonia entre assistência social e trabalho assalariado, ou remunerado, e concebem 
o acesso ao trabalho, mediado pela política de assistência social, como um direito do cidadão.

\section{Hipótese de trabalho}

Tendo em vista a elucidação do objeto construído a partir da contextualização do problema da pesquisa e das questões que nortearam as análises aqui desenvolvidas, foi elaborada a seguinte hipótese; isto é, a seguinte afirmação que funcionou como um recurso heurístico no desencadeamento do processo de aproximações sucessivas ao cerne do objeto:

Com o advento e aprofundamento do modo de produção capitalista o significado ontológico do trabalho - como necessidade vital e eterna que medeia a relação do homem com a natureza e entre os homens no seu processo de humanização - modificou-se, tornando-se um simples criador de mercadorias. Este trabalho modificado tem incumbido a assistência social a responsabilidade pela inserção de seus usuários no mercado de trabalho, por julgar esta a estratégia mais meritória de proteção aos pobres, esvanecendo a categoria direito que está na base das práticas assistenciais. Dessa forma, embora a assistência social e o trabalho assalariado estejam historicamente relacionados e em sintonia, esta relação é contraditória por criar, ao mesmo tempo, tensões e desvirtuamentos das suas capacidades precípuas.

Do lado da assistência social, ela perde prestígio quanto mais se associa a um direito do cidadão e se afasta do mérito, que constitui a capacidade do indivíduo de se autossustentar por meio do trabalho; e do lado do trabalho assalariado, típico do modo de produção capitalista, ele ganha prestigio quanto mais se associa ao mérito e se afasta do direito, embora neste caso o mérito passe a ser confundido com direito. Ou melhor, na perspectiva do trabalho a categoria direito é confundida com a tentativa de unificação dos diversos sentidos do trabalho ou a homogeneização dos tipos de trabalho -assalariado x ontológico/ mercadorizado x desmercadorizado/ precário $\mathrm{x}$ protegido - coisa que no modo de produção capitalista torna-se impossível, pela dissonância entre a natureza dos pares contrários: enquanto um é emancipador, 0 outro é escravizador; e é este que prevalece, subordinando, implacavelmente, o labor humano ao capital. 
É por essa ótica também que a ortodoxia neoliberal encara os demandantes da assistência como "lesadores" sociais, porque teriam condições de trabalhar, mas escolhem o patrocínio gratuito do Estado, por meio das políticas sociais. Não obstante, a partir da mudança no perfil dessas políticas (de socialdemocratas para neoliberais) estabeleceu-se o primado da ética capitalista do trabalho para quem o direito deve ceder espaço ao mérito do indivíduo de se autossustentar e de adquirir capacidade de satisfazer suas necessidades como consumidor.

\section{OBJETIVOS:}

\section{Geral}

Conhecer as razões mais ocultas, partindo das mais aparentes, do desvirtuamento da categoria direito produzido no seio da relação histórica e contraditória de sintonia e tensão entre a assistência social e o trabalho no modo de produção capitalista.

\section{Específicos}

- Analisar, historicamente, numa dimensão macro, como se desenvolve a relação de sintonia e tensão entre a assistência Social e o trabalho no modo de produção capitalista;

- Identificar como a ética capitalista do trabalho contribui para o desvirtuamento da categoria direito, ao reduzir o trabalho ontológico a trabalho assalariado, e ao restringir a ação da assistência social, como política concretizadora de direitos, à mera ativação de seus demandantes para o mercado laboral precarizado;

- Verificar, no contexto atual da relação contraditória indicada, a contraposição entre trabalho/mérito versus direitos/assistência social;

- Detectar, empiricamente, em dois programas socioassistenciais brasileiros -o Bolsa Família e o Acessuas -Trabalho - o domínio da ética capitalista do trabalho sobre o direito incondicional do cidadão de ser socialmente assistido em suas legitimas necessidades. 


\section{JUSTIFICATIVA}

O debate acerca deste tema de pesquisa, não é um exercício descolado do real, mas foi motivado a partir da inserção deste pesquisador no campo proposto, tanto politicamente como intelectualmente. Pode-se afirmar que debater a relação entre a assistência social e o trabalho, tentando desvendar teórica e politicamente suas nuances e implicações sutis na sociedade, representa uma tentativa de extrapolar o aparente (que prevalece na opinião pública) e de decodificar um discurso do senso-comum que legitima uma postura conservadora de volta ao passado.

Dito isso, é necessário evidenciar que o estudo da relação contraditória entre trabalho assalariado e assistência social já foi por nós iniciado, mesmo que de forma aproximativa e breve, no período de nossa graduação em Serviço Social, com a investigação para a elaboração do Trabalho de Conclusão de Curso - TCC (2014), intitulado - "A CULTURA DA AUSÊNCIA E DA OBRIGAÇÃO: dilemas e possibilidades traduzidas nas 'vozes' dos demandantes da política de Assistência Social no município de Muritiba - BA". Naquela discussão, apesar de termos nos debruçado sobre as normativas da política de Assistência Social e a formação social de uma cultura da obrigação (de ter que aceitar qualquer trabalho) e a repercussão disso na vida dos beneficiários do Programa Bolsa Família (PBF), já era latente a necessidade de aprofundar a relação tensionada entre os "direitos" decorrentes do trabalho e os direitos à assistência social.

Aliada a essa inquietação, que permaneceu neste estudo, houve o interesse de aprofundar a análise das seguintes características que vêm sendo modificadas por imposição da ética capitalista do trabalho em curso: i) o desvirtuamento do trabalho ontológico no modo de produção capitalista, transformando-o em assalariado; ii) o processo histórico da assistência social inserido neste modo de produção, que tem tensionado para o desvirtuamento da proteção e para o enfraquecimento do questionamento dos efeitos deletérios do trabalho assalariado, para adotar estratégias de ativação de seus demandantes para o mercado de trabalho precário; iii) a persistência genérica do entendimento de que os usuários da assistência social são "lesadores" da ética do trabalho, devendo-Ihes, por isso, oferecer contrapartidas (nesse caso o trabalho); iv) e a descaracterização da categoria direito, que passa a 
estar prioritariamente vinculada ao "direito" a obter qualquer trabalho (precário, instável, terceirizado).

Propaga-se, recorrentemente na mídia, a necessidade de enxugamento ou corte dos gastos sociais, por não gerarem lucros diretos para o capital e/ou dividendos políticos para projetos partidários que tentam vincular o acesso à proteção social à obrigação do trabalho. E uma das principais justificativas apresentada nesse discurso é o desincentivo ao labor, que tem histórica relação com o desagrado dos que se beneficiam com a exploração e a semiescravização de mão de obra barata, como as empregadas domesticas ou os trabalhadores dos canaviais. Por meio dessas informações repassadas, cotidianamente, à opinião pública, apreende-se a lógica liberal que encontra no trabalho assalariado o meio nato e exclusivo de bem-estar. $E$ isso demanda um debruçar aproximativo a essa realidade na perspectiva de desvendar a veracidade ou não dessas construções aqui apontadas.

Com esta dissertação, esperamos poder contribuir com o campo das políticas sociais, mais especificamente da assistência social, buscando descortinar possíveis equívocos conceituais que ainda perduram e também evidenciar o não-lugar que é imposto aos trabalhadores, a partir dessa relação, que tem perdido direitos sob a lógica da afirmação do trabalho assalariado. No momento histórico em curso, de regressão de direitos e confirmação de uma agenda que favorece a ideologia neoliberal, entendemos a atualidade do debate, tendo em vista: a manutenção dos privilégios da classe burguesa, escamoteados e apresentados à opinião pública como esforço próprio ou mérito; a adoção da ética capitalista, associada a qualquer trabalho; a meritocracia como substituta dos direitos; a crise estrutural do capital, que mundializa a barbárie; e o propósito desta dissertação de assumir o desafio de colocar em evidência e disputa, teórica e politicamente, os dilemas vivenciados por quem demanda e acessa a Assistência Social - os trabalhadores inseridos em condições precárias de produção e vida. 


\section{METODOLOGIA}

\section{Sobre o Método}

A análise pretendida tem como pressuposto o movimento constante da realidade, percebida como fruto da relação dialética entre estrutura e história e inserida em uma totalidade complexa e contraditória. Segundo Gil (1995), ao se reportar ao método guiado por princípios dialéticos,

[...] para [se] conhecer realmente um objeto é preciso estudá-lo em todos os seus aspectos, em todas as suas relações e todas as suas conexões. Fica claro também que a dialética é contrária a todo conhecimento rígido. Tudo é visto em constante mudança: sempre há algo que nasce e se desenvolve e algo que se desagrega e se transforma (GIL, 1995, p.32)

No processo da pesquisa, não há como alcançar o objetivo sem o uso de recursos mediadores que contribuam para a investigação do que não está aparente; ou seja, há a necessidade de se adotar um método que, segundo Quivy e Campenhoudt (2005), "nunca se apresenta como uma simples soma de técnicas (...), mas sim como um percurso global do espírito que exige ser reinventado para cada trabalho" (p.15) e subsidiado por procedimentos determinados.

Esse método tem recebido várias denominações; mas, dada à sua particularidade dinâmica, relacional e datada historicamente, ele será aqui designado como histórico-estrutural, por privilegiar a relação dialética entre os determinantes estruturais do objeto de estudo com a história construída por homens e mulheres no processo de produção e reprodução de sua existência em sociedades de classe; ou seja, um "método de pesquisa que propicia o conhecimento teórico, partindo da aparência, visando alcançar a essência do objeto" (NETTO, 2011, p.22).

Nesse processo de investigação do real, caracterizado por aproximações sucessivas, e apoiado em recursos heurísticos, entre os quais as indagações e suposições provisórias figuram como mediações estratégicas, a simples reprodução ideal da realidade no pensamento não configura uma formulação teórica fidedigna. Para tanto, há que se ter um método que se torna dialético porque a realidade estudada é dialética e exige ser compreendida como ela é. Eis porque 
começa-se 'pelo real e pelo concreto', que aparecem como dados; pela análise, um e outro elementos são abstraídos e, progressivamente, com o avanço da análise, chega-se a conceitos, a abstrações que remetem a determinações as mais simples. (idem, p. 42).

Portanto, o método dialético nesta pesquisa possibilita a apropriação crítica dos movimentos internos da realidade do objeto. Para se aproximar deste objeto, ultrapassando o que primeiramente ele apresenta, isto é, o mundo dos fenômenos, deve-se levar em consideração a lei de afirmação e negação, presente na realidade tornando-a dialeticamente contraditória. Por isso, a categoria contradição deve ser considerada em todo processo de conhecimento que começa com a investigação; e mais, em toda análise da realidade.

\section{Procedimentos Metodológicos}

Esta dissertação assume o entendimento da política social enquanto um processo articulado, matéria privilegiada e precípua no campo da proteção social, com influências reais na estrutura social e não meramente como ações políticas. Nesse sentido, as elaborações das correntes teóricas assumem protagonismo na disputa tanto pela concepção, como pela condução das políticas sociais, necessitando clarificar as compreensões e conflitos entre os estudiosos.

Desta forma, por meio da pesquisa bibliográfica buscamos qualificar os conceitos e as teorias, relacionando-os à realidade estudada. Segundo Gil (1995, p.71) "a principal vantagem da pesquisa bibliográfica reside no fato de permitir ao investigador a cobertura de uma gama de fenômenos muito mais ampla do que aquela que poderia pesquisar diretamente".

Com a intenção de construir e delimitar as categorias acerca do objeto resgatamos as principais construções teóricas já formuladas, em fontes secundarias ou indiretas (livros, artigos, dissertações e Teses), tendo como eixo a relação entre a assistência social e o trabalho.

Além disso, por meio da pesquisa bibliográfica, usamos o recurso da análise documental, para aliar as teorias estudadas à prática institucional e regulatória da assistência social e dos programas aqui analisados. As principais legislações que 
utilizamos foram: os marcos que instituíram e regulamentam a assistência social, bem como do Programa Bolsa Família; e do Programa ACESSUAS - TRABALHO; também os complementares que são divulgados pelo Ministério do Desenvolvimento Social e Combate à Fome - MDS.

Através destes recursos metodológicos, a proposta desta dissertação se situou na abordagem qualitativa, observando que esta abordagem, segundo Minayo (2001), "aprofunda-se no mundo dos significados das ações e relações humanas, um lado não perceptível e não captável em equações, médias e estatísticas" (p. 22). 


\section{CAPITULO 1}

\section{MARCO TÉORICO REFERENCIAL}

\section{FUNDAMENTAÇÃO CRÍTICA DO OBJETO DE ESTUDO A PARTIR DAS CATEGORIAS CENTRAIS DE ANÁLISE.}

\section{INFORMAÇÕES PRELIMINARES}

Este capítulo tem como eixo principal a elucidação das categorias centrais de analise que perpassam todo o percurso reflexivo percorrido na dissertação. Entendese, com lanni (2011) que a construção de categorias, "é o resultado de uma reflexão obstinada, que interroga o real reiteradamente, e que desvenda do real aquilo que não está dado, não é imediatamente verificado" (p. 398). Trata-se de um processo que coloca e recoloca sempre o problema da investigação em um contínuo movimento de captação e depuração de conhecimento para acercar-se de seu real significado.

As categoriais adotadas nesta dissertação já existem na literatura especializada e compõem o quadro referencial deste estudo. São elas:

- a contradição dialética, que perpassa, de forma orgânica, todas as demais categorias delimitadas, assim como o objeto de interesse privilegiado da pesquisa;

- o direito de cidadania, cuja importância reside no fato de constituir um contraponto à opressão e ao arbítrio do poder público e das classes dominantes em face das demandas e necessidades sociais;

- o mérito, como critério burguês, utilizado para negar direitos e legitimar privilégios com base na competição entre sujeitos socialmente desiguais;

- a Assistência Social, como política pública que, em tese, deveria concretizar direitos sociais, mas que tem sido usada como mecanismo de ativação ou "porta de saída" de seus demandantes para o mercado de trabalho precário; e 
- o trabalho assalariado, ou autorrentável, que, no modo de produção capitalista, desumaniza o ser humano e converte-se em um anti direito.

A partir da elucidação e da articulação destas categorias, poderemos demarcalas historicamente e destacar as nossas compreensões sobre os debates e inquietações levantadas pela pesquisa.

\subsection{CONTRADIÇÃO}

A categoria contradição assume protagonismo nas análises realizadas nessa dissertação, porque é a partir dela, como um movimento inerente à própria realidade que colocamos em questionamento e evidência, as múltiplas determinaçãoes do objeto pesquisado; determinações estas que não são lineares, mas dialéticas; e nem somente estruturais, mas também históricas. Segundo Mao Tse-tung (1999), "a lei da contradição inerente aos fenômenos, ou lei da unidade dos contrários, é a lei fundamental da dialética materialista" (p.31)

É por meio da análise crítica, ancorada em categorias fundamentais, como é a contradição, que se consegue apreender a materialidade contraditória dos fenômenos; ou seja, é com base nestas categorias que se apreende a dialética do real ${ }^{1}$. De acordo com Netto (2011), foi a partir da união das

três categorias nucleares - a totalidade, a contradição e a mediação -
, [que] Marx descobriu a perspectiva metodológica que lhe propiciou o
erguimento do seu edifício teórico. Ao nos oferecer o exaustivo estudo
da "produção burguesa", ele nos legou a base necessária,
indispensável, para a teoria social. (p.18).

Ou seja, a contradição, na perspectiva dialética ${ }^{2}$ não ocorre de forma isolada ou fragmentada, mas na totalidade concreta de imbricadas relações de menor

1 "Sem as contradições, as totalidades seriam totalidades inertes, mortas - e o que a análise registra é precisamente a sua contínua transformação. A natureza dessas contradições, seus ritmos, as condições de seus limites, controles e soluções dependem da estrutura de cada totalidade $-\mathrm{e}$, novamente, não há fórmulas/formas apriorísticas para determiná-las: também cabe à pesquisa descobri-las" (idem, p.17).

2 "A dialética é muito mais exigente do que o irracionalismo. Para reconhecer as totalidades em que a realidade está efetivamente articulada (em vez de inventar totalidades e procurar enquadrar nelas a realidade), o pensamento dialético é obrigado a identificar, com esforço, gradualmente, as 
complexidade que medeiam o alcance de conjuntos maiores e mais complexos de relações e processos.

Pode-se encontrar na concepção dialética hegeliana, qual Marx partiu e, posteriormente, criticou as bases para o entendimento da categoria contradição formulada por Marx. A lei da unidade dos contrários, demonstra que uma coisa nunca é igual a si mesma, pois, vive em um constante processo de mudança e autonegação constituindo a lei da negação da negação. Segundo Basbaum (1978) "quando uma coisa se nega a si mesma dá em resultado uma outra coisa (negação) que, por sua vez, é igualmente negada e assim sucessivamente" (p. 188, tradução nossa). Tal processo, nos termos de Hegel, denomina-se tese, antítese e síntese.

Por isso, Konder (1981), afirma que,

num sentido amplo, filosófico, que não se confunde com o sentido que a lógica confere ao termo, a contradição é reconhecida pela dialética como princípio básico do movimento pelo qual os seres existem" (p.49).

Se se compreende que tudo o que existe na realidade é movido por contradições, com o objeto de análise desta dissertação não poderá ser diferente. A relação de sintonia e tensão simultânea entre Assistência Social e Trabalho, que nesta dissertação procura-se decifrar, é contraditória porque contempla interesses recíprocos e antagônicos ao mesmo tempo de indivíduos, classes e projetos de sociedade que são constitutivos da organização social e política do modo de produção capitalista. No campo das disputas teóricas, ressalta a importância do aporte que procura apreender o movimento real que deverá embasar o conhecimento teórico sobre a assistência social e o trabalho, cuja relação entre ambos contempla contradições a serem desvendadas dialeticamente. Neste sentido, Konder (1981) esclarece que

a teoria nos ajuda, fornecendo importantes indicações. Em relação à totalidade, por exemplo, a teoria dialética recomenda que nós prestemos atenção ao "recheio" de cada síntese, quer dizer, às contradições e mediações concretas que a síntese encerra (p.44). 
A partir desse entendimento, torna-se possível compreender que as condições de questionamento da relação entre assistência social e trabalho, no modo de produção capitalista, somente serão fecundas se elas levarem em conta o caráter contraditório dessa relação. Segundo C. P. Pereira (2015),

é, de fato, a categoria contradição dialética, de filiação materialista histórica, que vai impedir que a análise da proteção social se enrijeça em visões lineares e parciais. Se por contradição dialética, no campo do bem-estar, se entender, como aqui entendido, um processo inserido numa totalidade contraditória cujas tendências refletem as raízes da sociedade capitalista - entre forças produtivas e relações de produção - ter-se-á em mente que a proteção social exibirá traços positivos e negativos, isto é: ela poderá atender interesses diferenciados, embora esteja estruturalmente comprometida com os interesses dominantes (p. 48).

Portanto, não constitui nenhum mistério que a manutenção do modelo de sociabilidade burguesa tem como fundamento a superexploração do trabalho e, por consequência, a busca vital pelo aumento de lucros; e, por isso, a sociedade humana torna-se "um acessório do sistema econômico" (POLANYI, 2000, p. 97) e os trabalhadores uma mercadoria barata, diante de sua disponibilidade e da falta de alternativas ao trabalho assalariado, gerador de mais valia.

Fundada num complexo multifacetado de contradições, a sociabilidade burguesa ${ }^{3}$ "é uma totalidade dinâmica - seu movimento resulta do caráter contraditório de todas as totalidades que compõem a totalidade inclusiva e macroscópica" (NETTO, 2011 p.56).

Mao Tse-tung (1999), condiciona o verdadeiro conhecimento da dialética materialista, ao estudo da lei da contradição, entendendo, nesse condicionamento, a necessidade de considerar um amplo leque de problemas e questões filosóficas. Dentre as questões elencadas pelo autor, destaca-se "a universalidade da contradição e a particularidade da contradição" (p.32).

Em relação à "universalidade da contradição", o autor expõe que,

\footnotetext{
3 "Enfim, uma questão crucial reside em descobrir as relações entre os processos ocorrentes nas totalidades constitutivas tomadas na sua diversidade e entre elas e a totalidade inclusiva que é a sociedade burguesa. Tais relações nunca são diretas; elas são mediadas não apenas pelos distintos níveis de complexidade, mas, sobretudo, pela estrutura peculiar de cada totalidade. Sem os sistemas de mediações (internas e externas) que articulam tais totalidades, a totalidade concreta que é a sociedade burguesa seria uma totalidade indiferenciada - e a indiferenciação cancelaria o caráter do concreto, já determinado como "unidade do diverso" (NETTO, 2011, p.18).
} 
a universalidade, ou caráter absoluto da contradição, tem um duplo significado: primeiro, as contradições existem no processo de desenvolvimento de todos os fenômenos; segundo, que, no processo de desenvolvimento de cada fenômeno, o movimento contraditório existe do princípio ao fim (p.38).

Sendo assim, em todos os fenômenos há a luta entre aspectos contraditórios, desde 0 início até 0 fim; e esse movimento ${ }^{4}$ é o responsável por produzir desenvolvimento e vida ativa aos fenômenos e ao mundo.

Entendendo a contradição como um movimento multideterminado e em constante mutação, considera-se que, para sua apreensão no mundo real, há sempre necessidade da análise tanto das singularidades dos fenômenos e ou, ao menos, de suas particularidades, tendo em vista que "no mundo, não há mais do que matéria em movimento, e o movimento da matéria assume sempre formas determinadas" (p. 43).

Desta maneira, no processo em que se busca conhecer determinado fenômeno concreto e extrapola-lo com novas contribuições, a análise da particularidade da contradição é a parte precípua, entendendo-a a partir da essência especifica multideterminada dos fenômenos, para após, chegar na generalização destes fenômenos. (idem, p. 44). Mas, não se limita ou extingue aí, é necessário "ir mais adiante e estudar os fenômenos concretos que não foram profundamente estudados ou que aparecem pela primeira vez" (p. 45). E o autor continua,

para fazer ressaltar a particularidade das contradições consideradas no seu conjunto ou na sua ligação mutua ao longo do processo de desenvolvimento de um fenômeno, quer dizer, para fazer sobressair a essência do processo, é necessário fazer ressaltar o caráter especifico dos dois aspectos de cada uma das contradições desse processo de outro modo é impossível fazer sobressair a essência do processo ( $p$. 46).

Desta forma, "cada contradição e cada um dos seus aspectos tem as suas particularidades, é nisso que reside a particularidade e o caráter relativo da contradição" (TSÉ-TUNG, 1999 p. 77). Assim, para o amadurecimento e mesmo o avanço do conhecimento da essência dos fenômenos, parte-se do particular ao geral e no caminho contrário do geral ao particular, ou seja, o aprimoramento do conhecimento "representa sempre um movimento em espiral e (se se observa

\footnotetext{
4 "Toda forma de movimento contém em si suas próprias contradições especificas, as quais constituem aquela essência especifica que diferencia um fenômeno dos outros. É essa a causa interna, a base, da diversidade infinita dos fenômenos no mundo" (TSE-TUNG, 1999, p. 43).
} 
rigorosamente o método cientifico) cada ciclo pode elevar o conhecimento a um grau superior e incessantemente mais profundo" (idem, p. 44).

Partindo então do método materialista-dialético, apreendendo as contradições inerentes ao nosso objeto, conseguiremos fazer uma análise dos "fenômenos na realidade objetiva" (idem, 1999, p. 69) ou seja,

a unidade ou a identidade dos aspectos contrários de um fenômeno que existe objetivamente nunca é morta, petrificada, mas, sim viva, condicionada, móvel passageira, relativa; todo aspecto contrário converte-se, em condições determinadas, no seu contrário (idem).

\subsection{DIREITO}

A centralidade da categoria Direito, passa pela sua constituição em um determinado padrão civilizatório que se contrapõe à ausência de democracia. Embora essa categoria possa ser capturada pela ideologia liberal, ficando restrita a sua dimensão civil e política, é por uma perspectiva ampliada, incluindo a dimensão social, que ela será tratada nesta dissertação. Portanto, a relação contraditória entre assistência social e trabalho, passará pelo crivo critico desta perspectiva, que não comporta a vinculação do direito, particularmente o social, a condicionalidades ou contrapartidas. Isso não anula a concepção de Bobbio (2004) de que "não há direito sem obrigação; e não há nem direito nem obrigação sem uma norma de conduta" (p.10). Mas, a obrigação não deve funcionar como moeda de troca.

Ao se debruçar sobre a constituição ou mesmo o significado do direito na história da humanidade, percebe-se a sua intrínseca relação com a categoria "poder". Nesta condição, o direito pode ser exercido individualmente tanto para privilegiar um "ser" que se julgue superior ou para legitimar ou não uma condição coletiva adquirida socialmente. Para Poulantzas (1974),

o direito moderno corresponde à exploração de classe e à dominação política de classe. [...] O desvendamento da relação constitutiva do direito e da luta de classes só pode ser cientificamente estabelecida por sua localização previa no conjunto complexo das estruturas de um modo de produção e de uma formação. Precisamente esta localização é a que nos dá as chaves para a investigação de sua relação com o campo da luta de classes (p. 49).

Sendo assim, Direito e poder estão circunscritos no âmbito do Estado e da luta das classes. Poulantzas (2007), ao se aproximar desse debate, afirma que, "las 
relaciones de las clases son relaciones de poder. Los conceptos de classe y de poder son afines, en la medida em que tienen como lugar de constitución el campo circunscrito por las relaciones sociales (p. 118). Pereira-Pereira (2008), a partir da historiografia da constituição dos direitos, demonstra que,

surgem, assim, na Idade Média, duas categorias de direito; o direito divino, "natural" e superior ao direito humano, e o direito dos homens, "positivo", e portanto, construído pelos membros da sociedade, em sua própria defesa contra o poder do Estado". (PEREIRA-PEREIRA, 2008, p. 28-29).

A autora ainda confirma que as relações estabelecidas no âmbito políticojurídico medieval, tem grandes contribuições na conformação da teoria do Estado e dos direitos modernos, sendo que "foi na era moderna que a noção de Estado de Direito ou de Estado limitado pela lei ganhou relevância" (p.29).

É necessário considerar que o significado e a materialidade do direito contemporâneo é fruto da construção das relações sociais na história do modo de produção capitalista e que, por isso e por apreender as contradições inerentes a essa realidade, assume os direcionamentos que a luta de classes impõe ao Estado, que é burguês. Ou seja, que legitima ou não determinados direitos.

De acordo com Pachukanis (1988), “apenas a sociedade burguesa capitalista cria todas as condições necessárias para que o momento jurídico esteja plenamente determinado nas relações sociais" (p. 24).

Sendo assim, ao se fazer referência ao direito ${ }^{5}$, ou a condição adquirida de direito, se está especificando um conjunto de condições que extrapolam as necessidades básicas e que se adquirem em sociedade, frente aos dilemas e vicissitudes cotidianas; e que conferem a inviolabilidade da vida e a cidadania distributiva aos desiguais. No modo de produção capitalista, a reprodução desses direitos é fruto de um "cabo de guerra" travada entre as classes e legitimada por meio da ação no âmbito do Estado.

Os direitos nessa condição, não devem ser confundidos com um aparato jurídico de legislações, que são mecanismos de instrução e provisão, e que podem legitimar ou não a condição de direito. Segundo Lyra Filho (1982),

\footnotetext{
${ }^{5}$ Aqui se está fazendo referência ao conjunto de direitos que são exclusivamente invioláveis, ou seja, "os direitos humanos fundamentais passaram a ser dirigidos para a proteção da dignidade, valor supremo que atrai o conteúdo de todos os direitos fundamentais, inclusive o direito à vida, posto que nem mesmo a morte das pessoas elimina seu tratamento dignitário" (SIMÕES, 2010, p. 79).
} 
a lei sempre emana do Estado e permanece, em última análise, ligada à classe dominante, pois o Estado, como sistema de órgãos que regem a sociedade politicamente organizada, fica sob o controle daqueles que comandam o processo econômico, na qualidade de proprietários dos meios de produção. Embora as leis apresentem contradições, que não nos permitem rejeitá-las sem exame, como pura expressão dos interesses daquela classe, também não se pode afirmar, ingênua ou manhosamente, que toda legislação seja Direito autêntico, legítimo e indiscutível (p.3)

A contradição é preponderante nessa questão da lei e do direito, pois, a condição que atesta a necessidade da constituição de determinado direito pode ser verificada e demandada; mas, ao mesmo tempo pode ser destituída e negada juridicamente por meio da ação contraria, ou seja, pela formatação de leis que impeçam a materialização do direito ${ }^{6}$, ou também pela não ação do Estado. Acerca dessa questão Lyra Filho (1982) afirma que,

a identificação entre Direito e lei pertence, aliás, ao repertório ideológico do Estado, pois na sua posição privilegiada ele desejaria convencer-nos de que cessaram as contradições, que o poder atende ao povo em geral e tudo o que vem dali é imaculadamente jurídico, não havendo Direito a procurar além ou acima das leis (p. 3)

Aqui, é necessário que se demarque o entendimento desta pesquisa acerca da ideologia que é inerente as ações ou omissões do Estado. Pachukanis (1988) afirma que, "o Estado não é apenas uma forma ideológica, mas, também, é ao mesmo tempo, uma forma do Ser social. A natureza ideológica de um conceito não suprime a realidade e a materialidade das relações por ele expressas” (p.39). Ou seja, só há Estado porque os sujeitos em sociedade o compõem e o legitimam, apesar de esse Estado no modo de produção capitalista, parecer um ente individual e superior ao

\footnotetext{
6 "O Direito autêntico e global não pode ser isolado em campos de concentração legislativa, pois indica os princípios e normas libertadores, considerando a lei um simples acidente no processo jurídico, e que pode, ou não, transportar as melhores conquistas. Isto depende, é claro, de que Estado, concretamente, surge a legislação - se ele é autoritário ou democrático; se reveste uma estrutura social espoliativa ou tendente à justiça social efetiva e não apenas demagógica e palavrosa; se a classe social que nele prevalece é a trabalhadora ou a capitalista; se as bases dominam o processo político ou a burocracia e a tecnocracia servem ao poder incontrolado; se os grupos minoritários têm garantido o seu "direito à diferença" ou um rolo compressor os esmaga; se, em geral, ficam resguardados os Direitos (não menos Direitos e até supra-estatais; isto é, com validade anterior e superior a qualquer lei), chamados Direitos Humanos" (LYRA FILHO, 1982, p.4).
} 
conjunto da sociedade, tendo em vista seu aparelhamento e o uso potencial da sua força.

Na especificidade da relação entre a Assistência Social e o Trabalho, esse conflito entre direito e lei pode ser verificada, por exemplo, na seguinte questão: o Estado institui a assistência social como um direito do cidadão, mas, ao mesmo tempo apreende no conjunto de leis e normatizações que materializam o direito, aspectos sutis para "autonomizar" os demandantes, leia-se: expulsá-los para o mercado de trabalho. Dessa forma, atesta o direito, mas, ao mesmo tempo impõe dilemas, pela via da legislação, na sua materialização.

Como esta dissertação se debruça sobre processos relacionados à política pública, é necessário distinguir e identificar a relação entre a categoria direito e modalidade de política. Segundo Pereira-Pereira (2008), "existem pelo menos duas categorias de direitos: os individuais e os sociais, sendo que os individuais se dividem em direitos civis e políticos" (p. 102), a exemplo do que é demarcado na Constituição brasileira, de 1988, como o direito de ir e vir (civil) e o sufrágio universal (político).

Mas, segundo a autora, os direitos que se vinculam às políticas públicas, são os direitos sociais, por terem como referência o princípio da igualdade, "embora tenham no seu horizonte os direitos individuais - que se guiam pelo princípio da liberdade" (idem, p.102). Essa associação entre direitos sociais e políticas públicas não é passiva (homogênea) ou sempre progressista, pois, a depender do direcionamento ideológico prevalecente, ela, em vez de se pautar pela igualdade e justiça, pode produzir desigualdades e injustiças, principalmente se obedecer a lógica do mercado. A justiça a que aqui se refere, não é a racional-legal, mas a que tem como horizonte a cidadania distributiva respaldada no critério da necessidade - a justiça social.

Pereira-Pereira (2006), ao se referir a essa justiça, afirma que ela,

possui um caráter substantivo ou material que requer a definição de critérios distributivos. Dentre esses critérios, o principal é o direito de todos ao que the é devido, [...], o qual deve ser concretizado por políticas de ação (políticas públicas, modernamente), que, diferindo do perfil clássico da política, tem como principal tarefa satisfazer necessidades sociais. Sendo assim, esse direito - que serve de critério distributivo de justiça - assume configuração social (PEREIRA-PEREIRA 2006, p.99). 
Por essa perspectiva os direitos sociais são desmercadorizados e têm como pressuposto o imperativo de considerar as similaridades, mas também as particularidades do real, legitimando a justiça; mas, corroborando com Mascaro (2002) ao dissertar sobre a concepção de direito em Marx, ele, ao se processar num contexto burguês, também pode legitimar a injustiça. Segundo Mascaro, "Marx dirá do direito o mesmo que disse do Estado, ou seja, vincula-o às relações históricas sociais capitalistas (p.30)

É nesta relação entre direitos sociais e políticas públicas que se confirma ou não a justiça social, materializando uma proteção social aos indivíduos que não se limita à dimensão biológica, mas a toda uma gama de atenções (cognitiva, emocional, econômica, social). A política pública ao se vincular à lógica do retorno ao trabalho, mesmo que de forma sutil, vai deixando de ser um direito incondicional, apesar das contradições que a realidade impõe, para um direito condicionado, provisório e limitado.

Nessa conjuntura, a conquista de direitos coletivos de quem apenas tem sua força de trabalho como meio de manutenção da vida, é considerada privilégio indevido, devendo ser repudiado, enquanto o esforço individual sob a lógica da meritocracia exaltado. Já os privilégios hereditários dos filhos da burguesia são mascarados sob a forma de mérito, esforço individual, descortinando uma forma inversa e perversa de responsabilização de insucessos, quando está em questão os direitos, e de merecimento quando estão em pauta os privilégios.

\subsection{MÉRITO}

No desenvolvimento dos direitos sociais, a construção de teorias que buscam deslegitimar as premissas que regem as práticas norteadas pela sua lógica e que legitimem a justiça social é recorrente, ou como afirma Hayek (1985) "a expressão 'justiça social' não pertence à categoria do erro, mas à do absurdo" (p. 98).

O neoliberalismo, que teve ampla adesão no contexto das políticas públicas brasileiras, transforma a abordagem dos direitos sociais, baseada na justiça social, em mérito e, consequentemente, privilegia as ações individuais, competitivas, a exemplo do trabalho assalariado e da ausência de qualquer tipo de proteção estatal. 
É a individualidade do desempenho e a busca do sucesso que se torna o pilar de sustentação das ações da sociedade no modo de produção capitalista.

Segundo Barbosa (2003), a meritocracia "refere-se a uma das mais importantes ideologias e ao principal critério de hierarquização social das sociedades modernas, o qual permeia todas as dimensões de nossa vida social no âmbito do espaço público" (p.21).

Se se analisar a relação entre a meritocracia e a história da formação social e econômica no contexto global, pode-se perceber que sua origem tem ramificações em todos os momentos históricos da sociedade moderna, pois, o mérito é a justificativa principal usada para os privilégios que a classe burguesa usufrui. "Além disso, do ponto de vista histórico, ela é considerada, desde a Revolução Francesa, o critério fundamental em nome do qual se lutou contra todas as formas de discriminação social" (BARBOSA, idem). Trata-se, segundo Barbosa, de "um conjunto de valores que postula que as posições dos indivíduos na sociedade devem ser consequência do mérito de cada um. Ou seja, do reconhecimento público da qualidade das realizações individuais" (p.22).

Segundo a referida autora, a meritocracia pode ser analisada por duas óticas: a negativa e a afirmativa. Quando se debate questões políticas e organizacionais, a partir da irrelevância de fatores hereditários, ou seja, valorizando os indivíduos independentemente das suas heranças, origem, posição social, econômica e/ou política, é a negativa que está em ação. Mas, ao afirmar que o critério para a organização social é o desempenho pessoal, considerando o "esforço" e a busca pelo sucesso, está em ação a meritocracia em sua dimensão afirmativa (idem, p. 22).

É esta dimensão afirmativa que é referida nesta dissertação, assentada na ética capitalista do trabalho que hierarquiza e condiciona uma escala de merecedores e não merecedores de reconhecimento e apreço públicos. Assim, de um lado, há os que merecem proteção devido ao esforço próprio por meio da venda da sua força de trabalho e, de outro, os não-merecedores, que, por não trabalharem, ficam na dependência da intervenção protetora do Estado.

É esse critério de mérito que tem fundamentado as políticas sociais no modo de produção capitalista, buscando no encaminhamento ativo e, por vezes compulsório, dos demandantes da assistência social para o mercado de trabalho 
precário, uma via de autossustentação. Além disto, para se ter acesso a essas políticas, tais demandantes devem submeter-se aos ditames do mercado laboral e demonstrar sua "incapacidade" de autossustento.

Para além dessa vinculação entre a política de assistência social e o trabalho, outras políticas também contemplam nas suas normativas essa lógica mercadológica e de disposição sutil para o trabalho remunerado. É o caso da educação que, em tempos de capital desregulado, tem se norteado também pela lógica da formação técnica e preparo aligeirado da mão de obra ${ }^{7}$, ao adotar como princípio orientador a formação para o trabalho assalariado ao invés da construção crítica do pensamento.

Dando sustentação a essa lógica mercadológica, Hayek (1985) em sua "Miragem da justiça social", afirma que,

sem dúvida é importante que, na ordem de mercado (ou sociedade fundada na livre iniciativa, enganosamente chamada de 'capitalismo'), os indivíduos acreditem que seu bem-estar depende, em essência, de seus próprios esforços e decisões. De fato, poucas coisas infundirão mais vigor e eficiência a uma pessoa que a crença de que a consecução das metas por ela mesma fixadas depende sobretudo dela própria. Por isso tal crença é frequentemente encorajada pela educação e pela opinião dominante em geral, ao que me parece, para grande benefício da maior parte dos membros da sociedade em que reina, os quais deverão muitos progressos materiais e morais importantes a pessoas por ela guiadas (p. 110).

É essa a tendência que está em curso: a de individualizar o insucesso, com a vinculação de toda a construção de direito à lógica do mercado, ou ao trabalho assalariado, tendo como um dos mecanismos de socialização da meritocracia, a oferta de treinamentos profissionais, exigidos pelo mercado; ou seja, quanto mais cursos os demandantes realizam, maior é o sentimento de que a sua dignidade está na possibilidade de sua inserção no trabalho assalariado e expulsão prematura do sistema de proteção social. Segundo Camila Pereira (2013),

dada a essa circunstância, para que o indivíduo se torne merecedor de um mínimo de proteção social pública precisará provar a sua derrota e incapacidade de superá-la via empenho próprio. E ao proceder desta maneira, os direitos sociais arduamente conquistados perdem seu

\footnotetext{
7 “Dos Princípios e Fins da Educação Nacional - Art. 2ำ A educação, dever da família e do Estado, inspirada nos princípios de liberdade e nos ideais de solidariedade humana, tem por finalidade o pleno desenvolvimento do educando, seu preparo para o exercício da cidadania e sua qualificação para 0 trabalho" [grifos nossos]". (BRASIL, 2005, p. 7).
} 
caráter civilizador, transformando-se em ajuda ou favor ofertado não aos que tem acesso à cidadania, mas aos que provam estar à margem dela. Neste caso, o mérito é o da necessidade, da privação (p.59).

É nesse campo ideológico que se ergue e se consolida o mérito na sociedade burguesa; e se manifestam padrões morais enviesados, baseados na cultura da utilidade competitiva, oprimindo quem não se encaixar na condição individualizada do sucesso, principalmente por meio dos frutos do trabalho precário; ou seja,

o individuo é assim concebido como fonte autônoma de suas decisões e de seus atos, consistindo o reconhecimento do discernimento individual como instância suprema, que não deve submeter-se a nenhuma autoridade superior. Essa concepção é fundamental para a sociedade capitalista, cujas relações sociais de produção assentam no reconhecimento da autonomia individual, na propriedade privada e no regime contratual, sobretudo da força de trabalho (SIMÕES, 2010, p.72).

Com base no exposto, entende-se a meritocracia no Brasil como uma cláusula socioeconômica e racial de barreira, que tem se sustentado na história das civilizações, no jogo contraditório entre manutenção e formação de novos privilégios e se intensifica no modo de produção capitalista, apreendendo e potencializando, no bojo da sua constituição, os resquícios de opressão das sociedades pré-capitalistas.

Não é por acaso que a lógica do mérito no Brasil esteja intrinsecamente ligada à questão racial, tendo em vista que neste país do "império escravocrata e da aurora burguesa" (PRADO JR., 2012), se dividia entre uma minoria que garantia os privilégios hereditários dos seus filhos e netos, por meio da exploração da mão de obra negra, e a grande massa populacional trabalhadora expropriada e escravizada nos latifúndios. Por isso, "pode dizer-se que a presença do negro representou sempre fator obrigatório no desenvolvimento dos latifúndios coloniais" (HOLANDA,1995, p. 48).

Nas disputas ideológicas, a meritocracia é pautada pela ala liberal do espectro político, sem considerar os determinantes socioeconômicos e raciais que incidem sobre cada indivíduo, como se a realidade fosse mecanicamente igualitária. Nesses termos, apagar-se-ia a história recente da escravização do povo negro; ou a exclusão e inserção precária da mão de obra feminina no mundo do trabalho; ou mesmo a pobreza extrema da classe que vive da venda da sua força de trabalho; e a partir desse corte histórico, a meritocracia seria uma borracha, que apagaria a formação da 
realidade brasileira e dotaria os indivíduos de largada única e igualitária no contexto das oportunidades.

Em contraposição, a igualdade social, que é pautada pela perspectiva socialista, fundamenta-se na posição social dos indivíduos na estrutura da sociedade, que não admite existência de classes sociais. Logo, o acesso e fruição da riqueza produzida coletivamente é de propriedade coletiva, cuja distribuição se rege pelos princípios da cooperação e da solidariedade e não da competição. Isso não significa que não se considere as individualidades e escolhas particulares, mas estas pertencem ao terreno da subjetividade no qual podem ser melhor atendidas pelos próprios sujeitos a partir de uma base material que lhes garanta condições objetivas de vida, de produção associada no campo do trabalho e de proteção social como direito de todos.

Mas, é a lógica do mérito e da igualdade formal ou de oportunidades, que tem sido adotada pelas políticas sociais, no sistema capitalista, e, no caso da Assistência Social, constituído estratégias que negam direitos.

\subsection{Assistência Social}

É necessário evidenciar que as análises contidas neste item, fazem parte de um esforço recente, no Brasil, de construir e delimitar a concepção teórica da assistência social. E, em consonância com esse esforço, tem-se ciência de que discorrer sobre essa política social implica confrontá-la com a realidade, na qual ela se produz e se processa, que é sua base material de sustentação empírica.

A assistência social, tem na sua história recente a construção enviesada da lógica dos direitos, ao ter sido pautada por mecanismos de cunho particularista, por testes de meios e por exigência de condições de não cidadania na elegibilidade dos demandantes à fruição de seus benefícios e serviços. Essa condição de não política concretizadora de direitos só viu uma mudança significativa, embora apesar de contraditória, mas, de grau efetivo formal, a partir das lutas pela inserção da Seguridade Social na Constituição Federal de 1988 e, mais especificamente, da Lei Orgânica da Assistência Social - LOAS, de 1993. Segundo Boschetti (2016), 
capitalistas, sobretudo nos países do capitalismo central, mas também, em menor grau, nos países do capitalismo periférico, que passaram a inclui-la como política de seguridade social (p. 76).

Esse histórico da Assistência Social é, sem dúvida, importante para dimensionar sua trajetória secular e também demonstrar seus limites e possibilidades; mas, isso será tratado, com mais detalhes, em capítulos posteriores. No momento, vale refletir sobre os problemas conceituais dessa política que derivam de preconceitos e da descaracterização de seu verdadeiro significado e papel social. Segundo Pereira-Pereira (1996),

O que tem tornado a assistência um fenômeno conceitualmente problemático, face aos cânones técnico-cientificos, é o adjetivo social que a complementa. É o termo composto assistência social que encerra uma pejorativa conotação que igualmente constrange e estigmatiza provedores e destinatários de benefícios e serviços assistenciais. Por este viés prestar socialmente assistência a quem precisa é, aos susceptíveis olhares técnicos profissionais - e guardadas as devidas peculiaridades -, tão desabonador quanto fazer "politicagem" ou ser um "mero burocrata". É, por conseguinte, a imprecisão, o desprestigio e a largueza interpretativa do adjetivo social que tem transformado a assistência em alvo de preconceitos (p.11).

Essa questão pode ser encarada por alguns como de menor importância ou já superada, tendo em vista que se baseia num conflito terminológico; mas, o uso reiterado desse entendimento, baseado no senso comum, impõe, subrepticiamente, uma lógica perversa na operacionalização dessa política. Portanto, ao negar no discurso e desvirtuar na prática o verdadeiro conteúdo e finalidade da assistência social, a sua noção, suprime um histórico de lutas e conquistas de atores que travaram no Brasil, grandes debates para a superação de sua condição de não política pública; e, além disto, traz "graves prejuízos para o conhecimento e a prática científicos" da mesma (idem, ibdem), como se já não fosse grave a tradição do primeiro damismo ${ }^{8}$ no comando desta política que reafirma a prática patriarcal de atribuir à assistência e à mulher a função de benemerência.

Nos estudos disponíveis sobre políticas sociais, depara-se com um volumoso número de análises acerca da assistência social, as quais se concentram nas suas ações e resultados, destacando realidades e experiências de gestores e profissionais.

\footnotetext{
${ }^{8}$ Cargo ocupado pela esposa dos governantes, nas três esferas da federação (União, estados e municípios, além do Distrito Federal), sem que esta precise ter preparo para exercê-lo.
} 
Contudo, apesar desta produção, que sem dúvida contribui para o avanço da tematização do processamento da proteção assistencial, há ausência ou reduzido esforço quanto à sua teorização.

Essa constatação é importante por reconhecer que a assistência social ocupa um lugar estratégico no contexto da proteção social, que complexifica o entendimento de sua presença no circuito das respostas políticas do Estado em face das demandas sociais que lhes são dirigidas.

Em verdade, no modo de produção capitalista a assistência social tem uma funcionalidade que não se explica intuitivamente, mesmo que esteja clara a sua utilização para a coesão social e, por consequência, para a manutenção do sistema do capital; desta forma, ao mesmo tempo que a submissão da assistência social suscita questionamentos teóricos a respeito de sua real serventia, propõe indagações referentes às potencialidades dessa política de mediar resistência ao poder do capital, em articulação com as demais políticas sociais.

Um esforço para desvendar teoricamente o seu significado, contribui para não criar expectativas exageradas em relação a ela e nem subestimá-la. O importante é entendê-la em acordo com o seu movimento e tempo histórico determinados.

Ao dissertar sobre assistência social burguesa, Pereira-Pereira (1996) afirma que as contradições vividas por ela, "seja no primeiro, terceiro ou quarto mundos -, depara-se, em todos eles, com um denominador comum: o dilema de atender demandas referentes às necessidades humanas" (p. 48), em um sistema dominado pela lógica da rentabilidade econômica privada. Ou seja, trata-se

de uma assistência social que, antes de ser ação programática ou um conjunto de medidas que visa atender demandas e necessidades de segmentos populacionais pobres, é produto e expressão objetivada de conflitos de interesses, exigindo do Estado e da sociedade a participação (p.48).

Ao contrário das muitas críticas em relação à assistência social, que vão de uma possível centralização desta no âmbito da proteção social, até as mais equivocadas, que afirmam a centralidade desta na resolução da pobreza, defende-se, nesta pesquisa, que

a sua função tem sido, através dos tempos, muito mais a de apontar para a necessidade de ampliação de direitos e de denunciar, silenciosamente, as iniquidades sociais produzidas pelo mercado, do que de reverte-las (idem, p. 49). 
Com efeito, por meio da assistência social pode-se verificar as diversas ausências, ou déficits, na vida de seus demandantes, que não são de exclusiva responsabilidade dessa política; daí a sua característica de perpassar as demais políticas sociais funcionando como elo aglutinador ${ }^{9}$. Outra característica pouco visível da assistência social é a denúncia nela embutida da ineficácia da lógica mercadológica do bem-estar individual, que submete os demandantes da proteção social pública aos critérios da autossustentação, em nome de uma suposta liberdade oferecida pelo o trabalho.

Neste cenário, Pereira-Pereira (1996, p. 50), distingue a assistência social com base na disjuntiva "stricto sensu" e "lato sensu". Para a autora, a assistência social "stricto sensu", seria "aquela ação tópica, circunstancial e sem garantia legal, voltada, mecanicamente, para minorar carências graves, que deixaram de ser assumidas pelas políticas socioeconômicas setoriais". Esta seria caracterizada pela atenção às urgências, ou baseada na indignação pontual em relação à pobreza; e sua contribuição final seria a de retroceder os direitos conquistados.

Na contramão dessa lógica, a assistência social "lato sensu" seria "apoiada na noção de pobreza relativa e em evidências empíricas" observadas e analisadas. Seu papel seria a de articular as demais políticas no intuito de garantir uma abrangência multidimensional da atenção assistencial. É através dessa análise que se compreende o equívoco em conceituar a assistência como uma política de promoção para o emprego, ou seja,

a assistência social não é um fenômeno marginal e transitório, que encontra o seu limite na promoção de políticas de emprego e de renda ou na integração dos pobres no mercado de trabalho. Trabalho assalariado, sem assistência social, ou seja, sem a proteção social do Estado como exigência da sociedade, é sinônimo de acumulação primitiva ou de alienação (idem, p. 52).

\footnotetext{
${ }^{9}$ Apesar das contradições que perpassam a materialidade da Assistência Social, tendo em vista sua inserção no real, esta "não é ação incompatível com as demais políticas sociais, muito menos com o trabalho. Na verdade, ela é condição necessária para que as políticas de atenção às necessidades sociais, engendradas pelos mecanismos excludentes do mercado, inclusive o mercado de trabalho, se efetivem como direito de todos. Sem a assistência social, as políticas sociais setoriais tendem a se elitizar, a se fechar na sua especialização e a se pautar por critérios que privilegiam mais a exclusão do que a inclusão social de sujeitos" [...] "a assistência social, por sua natureza e finalidade, não é propriamente uma ação complementar às demais políticas, mas, seu elo orgânico de ligação" (PEREIRA-PEREIRA, 1996, p. 52-53)
} 
A assistência social "lato sensu", como já mencionado, ao procurar aglutinar as políticas de atenção, aponta para a inclusão, ao contrário da "stricto sensu" que direciona para a exclusão. Segundo a referida autora a "lato sensu" contempla as características de ser "genérica na atenção e especifica nos destinatários, ao contrário das políticas sociais setoriais, que são genéricas nos destinatários e especificas ou especializadas na atenção" (p. 53).

Outra questão que perdura na assistência social, (seja por conveniência e/ou desejo de desqualificação ou por desconhecimento do movimento dessa política), mais especificamente no imaginário tanto de políticos, como de profissionais, e porque não de alguns estudiosos, são os equívocos presentes na sua definição. Um equívoco comum, é a vinculação da assistência social à pobreza ${ }^{10}$, ou seja, só existe essa política social se houver a pobreza.

Pode-se atribuir esta vinculação aos seguintes vieses: pela histórica ligação de suas práticas com a pobreza absoluta; pelo uso da assistência social pelas lideranças políticas como moeda de troca e de favorecimento político sendo ainda bastante recorrente nos municípios; pela tentativa de uniformizar a pobreza, como se ela não fosse dotada de multidimensão e complexidade estrutural;

A assistência social aparece nessa interpretação como dispensável, ou provisória, caso haja o fortalecimento das categorias de: "política social, direito de cidadania, promoção social e trabalho remunerado"; ou seja, a assistência social só seria demandada pela fraca atuação destas categorias (idem, p.21); e na lógica mercadológica das políticas sociais o fortalecimento de qualquer trabalho seria vital para o desaparecimento da assistência. "Dessa forma, a relação que a assistência

\footnotetext{
10 "Com raras exceções, a noção de pobreza que informa a assistência social é a pobreza absoluta ou extrema e não a pobreza relativa ou a desigualdade social, ou mesmo a recente noção de exclusão social que ultrapassa o universo restrito x privação biológica e da ausência de renda. Pobreza absoluta constitui, portanto, uma categoria restrita, consagrada pela ideologia liberal ou neoliberal, a qual justifica e prioriza ações focalizadas e emergenciais, que suprem paliativamente (quando suprem) sintomas de carências profundas, Sendo assim, a assistência social torna-se de fato, um anti-direito que, logicamente, não promove e nem livra o pobre da privação extrema, reforçando as negativas opiniões sobre ela. Além disso, tal noção de pobreza estimula, no nível operacional, a legitimação de mecanismos de restrição da demanda por benefícios e serviços assistenciais, tendo em vista a expansão do processo de privatização das políticas públicas e a redução do gasto público na área social" (PEREIRA-PEREIRA, 1996 p. 25)
} 
social teria com essas categorias é apenas de antagonismo e não de reciprocidade" (idem).

\subsection{Trabalho}

Nesta pesquisa a importância da categoria trabalho deve-se dois principais direcionamentos: primeiro, porque o trabalho é responsável pela passagem do "homem natural, para o homem social"; ou seja, no processo de transformação da natureza para fins de uso próprio, o homem também se transforma e se humaniza, construindo relações e formas de socialização ${ }^{11}$. Marx (2004a) ao falar desse movimento, afirma que o homem,

põe em movimento as forças naturais pertencentes à sua corporalidade, braços e pernas, cabeça e mão, a fim de apropriar-se da matéria natural numa forma útil para sua própria vida. Ao atuar, por meio desse movimento, sobre a natureza externa a ele e ao modificá-la, ele modifica, ao mesmo tempo, sua própria natureza (p. 30).

É, portanto, o trabalho que confere humanidade ao homem, distanciando-o de uma condição animalesca; e mais, confere a possibilidade de as capacidades humanas construírem instrumentos para um processo de trabalho mais eficaz de acordo com a sua necessidade. Segundo Engels (2004), "o trabalho começa com a elaboração de instrumentos" (p. 18). Essa capacidade teleológica, que é exclusivamente humana, ou seja, de fazer uma previa ideação e transformação de algo ainda no pensamento, confere ao homem o aperfeiçoamento tanto do processo do trabalho, como dos frutos da ação. Assim, conforme o referido autor,

só o que podem fazer os animais é utilizar a natureza e modificála pelo mero fato de sua presença nela. O homem, ao contrário, modifica a natureza e a obriga a servir-lhe, domina-a. E aí está, em última análise, a diferença essencial entre o homem e os demais animais, diferença que, mais uma vez, resulta do trabalho (idem, p.23).

11 "O homem é um animal que se fez homem através do trabalho. O trabalho como luta pela existência e práxis social é elemento primordial da hominização/humanização" (ALVES, 2007, p. 4). 
Pode-se, assim, afirmar que o trabalho encontrado em todas as civilizações, só pode ser definido a partir da consciência da necessidade de interação e transformação entre homem e natureza e da modificação dos materiais em estado natural para uso comum, seja para o consumo, seja para os processos de trabalho. "O trabalho, porém, é muitíssimo mais que isso. É a condição básica e fundamental de toda vida humana. $\mathrm{E}$ em tal grau que, até certo ponto, pode-se afirmar que o trabalho criou o próprio homem" (idem, p.11).

Esse trabalho é, conforme análise marxiana, de caráter ontológico, isto é, fundador do ser social pelo movimento dialético de interação entre homem-natureza, por meio do qual, produzem-se valores de uso para a satisfação das necessidades humanas. Na sociabilidade do modo de produção capitalista, a força que transforma a natureza, isto é, a força de trabalho, é transformada em mercadoria, que é apropriada pelos donos dos meios de produção assim como o produto desse trabalho. Cria-se assim um trabalho que escraviza o homem - o trabalho assalariado - do qual é retirado um valor excedente, mediante exploração, e que vai alimentar o lucro dos proprietários dos meios de produção, ao mesmo tempo em que empobrece e desumaniza o trabalhador.

Torna-se necessário destacar a diferenciação entre "trabalho vivo" 12 e "força de trabalho". Nesse debate Alves (2007) esclarece que,

a categoria "trabalho vivo" não se reduz à categoria "força de trabalho". O trabalho vivo possui como dimensão ineliminável, a força de trabalho, que pode ser considerada a capacidade física e espiritual da corporalidade viva voltada para a produção de objetos (p. 4).

Sendo assim, ao adquirir substância e desenvolvimento, o modo de produção capitalista, dissocia e opõe vida e trabalho, a força de trabalho que é investida não em satisfação humana, mas em instrumento de mercadorias, portanto capaz de produzir mais-valia; ou seja "uma parte do homem burguês é mercadoria, força de trabalho,

12 "O trabalho vivo é a dimensão anímico-pessoal do homem ciativo, sujeito de vontade e de desejo, elemento compositivo do produtor autônomo, instancia imprevisível como a lógica da vida, insubmissa à quantificação da sociedade do valor-trabalho e que se contrapõe, na sintaxe marxiana, ao trabalho morto, identificado com maquinas, autômatos adequados à produção capitalista" (ALVES, 2007, p.5). 
capaz de produzir mais-valia. A outra parte do homem burguês é vida, trabalho vivo" (Idem, p.5), que tenta resistir à opressão que o sistema engendra.

É o trabalho vivo permeado por imprevisibilidade e revolta que suscita constantemente a necessidade de o capital substituir o trabalho vivo por trabalho morto; mas, por outro lado, para a acumulação por meio da extração da mais-valia, a força de trabalho que contem no Trabalho vivo é primordial.

É por toda essa complexificação no mundo do trabalho que "como expressão da realidade existente na sociedade regida pelo valor tem-se a dialética da riquezamiséria, da acumulação-privação, do possuidor-despossuido" (ANTUNES, 2006, p. 126).

O trabalho assalariado, ou seja, abstrato ${ }^{13}$, enquanto estratégia de compra da força de trabalho, é a forma encontrada no modo de produção capitalista, que lança o trabalhador à própria sorte, submetendo-o a formas mais cruéis de sofrimento. Assim, "a utilização da força de trabalho é o próprio trabalho. O comprador da força de trabalho a consome ao fazer trabalhar o vendedor dela" (MARX, 1985, p.149).

Essa é uma questão central na teoria do valor de Marx, o trabalho abstrato. É necessário, porém, que se destaque que a compreensão deste estudo sobre do trabalho abstrato, não se aproxima de uma leitura que considera apenas a condição fisiológica do trabalho; esta dimensão é importante, pois seria muito difícil trabalho sem emprego de força humana, mas, o objeto desta pesquisa ultrapassa essa condição. De acordo com Rubin (1987),

O dispêndio de energia humana como tal, num sentido fisiológico, não é ainda trabalho abstrato, trabalho que cria valor, muito embora esse dispêndio seja sua premissa. O que caracteriza o trabalho abstrato é a abstração das formas concretas de trabalho, relação social básica

13 “O trabalho geral abstrato, que está no primeiro capítulo de o Capital, e que é fundamental para a compreensão de vários outros capítulos, mais valia, etc., não é dado empiricamente. Essa que é a realidade; esse que é o desafio. Porque a mercadoria não é um trabalho cristalizado na visão empírica, a mercadoria é matéria, é couro, é ferro, é tinta, é tecido, não é trabalho. Quem inventou que mercadoria é trabalho? Só um louco. Quer dizer, na verdade essa invenção é o resultado de uma reflexão obstinada sobre a realidade que desvenda o segredo da mercadoria, que é o de ser trabalho cristalizado. Só que ela não é só o trabalho do marceneiro, do pedreiro, do sapateiro, do tecelão; ela é o trabalho social abstrato, o "trabalho geral". Isto é, ela se constitui como valor em decorrência das trocas; e ela ganha, adquire valor no nível daquela norma de trabalho dos mais diversos que constituem uma comunidade de trabalho; isto é, em conjunto, como se fosse um somatório de vários e diferentes trabalhos que, no processo de troca, constitui um quantum de trabalho geral, abstrato, que, por repercussão, vai conferir a cada parte de mercadoria particular o seu valor" (IANNI, 2011, p.398). 
entre produtores mercantis separados [...] O trabalho abstrato não é uma categoria fisiológica, mas, uma categoria social e histórica ( $p$. 159).

O trabalho, no modo de produção capitalista, assume também a característica de fator de enriquecimento, e sua apropriação pelo capitalista adquire, segundo Marx (2004), dois aspectos:

Primeiro: o trabalhador trabalha sob o controle do capitalista a quem pertence seu trabalho. O capitalista cuida de que 0 trabalho se realize em ordem e os meios de produção sejam empregados conforme seus fins, portanto, que não seja desperdiçada matéria-prima e que o instrumento de trabalho seja preservado, isto é, só seja destruído na medida em que seu uso no trabalho o exija. Segundo: o produto, porém é propriedade do capitalista, e não do produtor direto, do trabalhador. O capitalista paga, por exemplo, o valor de um dia da força de trabalho (p. 39).

Desta forma o trabalho sob o domínio do capital deixa de ser para uso comum, podendo, nesse modo de produção, ser negociado, comprado e exaurido até as últimas forças do trabalhador; portanto, "na sociedade capitalista, o trabalho torna-se assalariado, assumindo a forma de trabalho alienado, fetichizado e abstrato" (ANTUNES, 2010, p. 10).

A degradação do trabalho, porém, não se limita a este movimento; com o modo de produção capitalista e a apropriação dos meios de produção, surge a ambição crescente do capitalista por mais lucros, pela apropriação da mais-valia, e só por meio da exploração e transformação do trabalho em mercadoria que se efetiva a obtenção de mais lucros. Segundo Alves (2007),

na verdade, esta é a condição fundamental (e fundante) do modo de produção capitalista. Não existiria sociedade capitalista sem mercadorização da força de trabalho. É por meio da exploração da força de trabalho como mercadoria que ocorre a extração de maisvalia e a acumulação do capital. A produção de mais-valia é o cerne essencial do sistema capitalista (p. 95). 
Há, nessa modificação do trabalho, a direta transformação e hierarquização dos trabalhadores - produtivos e improdutivos ${ }^{14}$. Essa "adequação" tem como direcionamento distinguir os que produzem ou não a mais valia. Segundo Marx (1978),

como o fim imediato e [o] produto por excelência da produção capitalista é a mais-valia, temos que só é produtivo aquele trabalhador - e só é o trabalhador produtivo aquele que emprega a força de trabalho - que diretamente produza mais-valia; portanto, só o trabalho que seja consumido diretamente no processo de produção com vistas à valorização do capital ( $p$. 70).

Por meio dessas transformações do trabalho no modo de produção capitalista pode-se verificar que é errônea as análises que consideram de forma taxativa, ou seja, sem considerar a contradição, que esta forma de trabalho é um direito, pois enquanto este trabalho é punitivo e fadiga os trabalhadores ${ }^{15}$, o direito quando legitimado sob uma lógica de justiça social, é responsável por questionar as condições degradantes e garantir melhores condições de vida, sendo: trabalho assalariado = direito, uma equação incompatível no capitalismo.

14 "Só é produtivo o operário cujo processo de trabalho é igual ao processo de consumo produtivo de capacidade de trabalho - do depositário deste trabalho - por parte do capital ou do capitalista" (MARX, 2013, p. 127).

15 "Daí que o trabalhador só se sinta junto a si fora do trabalho e fora de si no trabalho. Sente-se em casa quando não trabalha e quando trabalha não se sente em casa. O seu trabalho não é, portanto, voluntário, mas compulsório, trabalho forçado. (...) não é a satisfação de uma necessidade, mas somente um meio para satisfazer necessidades fora dele. A sua alienidade emerge com pureza no fato de que, tão logo não exista coerção física ou outra qualquer, se foge do trabalho como de uma peste. O trabalho exterior, o trabalho no qual o homem se exterioriza, é um trabalho de autosacrifício, de mortificação [...]" (MARX, 1989, p. 153). 


\section{CAPITULO 2}

\section{AS RAIZES DO TRABALHO NO BRASIL \\ ENTRE A PRISÃO ESCRAVISTA À FALSA LIBERDADE DO TRABALAHO ASSALARIADO}

Dissertar, sem equívocos, sobre o Trabalho no Brasil, não é tarefa simples. É, antes de tudo, um esforço que deve evidenciar as bases de formação e desenvolvimento da sociedade, observando as mudanças histórico-econômicas e sociais que impuseram e impõem características próprias à realidade nacional. Com este propósito, este capítulo aponta as particularidades da formação social e econômica brasileira e os dilemas que se refletem na conjuntura contemporânea do trabalho e na vida da classe que vende a sua força de trabalho como mercadoria.

Acredita-se que esse debate fornece subsídios para confirmar a história de negação de direitos e de desproteção a que esses trabalhadores estão submetidos, numa sociedade com raízes escravocratas cuja elite burguesa só prestigia o trabalho assalariado como um contraponto à socialização da cidadania social.

\subsection{O trabalho "livre" e desprotegido numa sociedade de raiz escravista.}

De antemão, devemos evidenciar que o desenvolvimento da classe trabalhadora no Brasil tem em sua raiz formas de imposição de normas e modos de organização destinados à manutenção de privilégios. A partir daí podemos destacar dois importantes movimentos históricos.

Um encabeçado pelos senhores brancos donatários da terra que, por meio da violência e da barbarização da vida, eram proprietários dos negros escravizados; e outro, caracterizado por uma transição não gradual nem homogênea, da sociedade escravista para a da "livre" concorrência, ou da "ordem social competitiva"16, cujo

16 "Ao absorver o capitalismo como sistema de relações de produção e de troca, a sociedade desenvolve uma ordem social típica, que organiza institucionalmente o padrão de equilíbrio dinâmico, inerente à integração, funcionamento e diferenciação daquele sistema, e o adapta às potencialidades econômicas e socioculturais existentes. Essa ordem social tem sido designada, por 
brancos, donos dos meios de produção (das terras e maquinários), também detinham as condições materiais para impor e se apropriar, pela via do assalariamento ${ }^{17}$, da mão de obra dos trabalhadores "livres", que conseguiam se inserir nesse novo modelo. De acordo com Alves (2007),

é claro que, antes do modo de produção capitalista, existia no modo de produção escravista, a cisão da relação natural homem-meio de produção. No trabalho escravo, o produtor, além de não ser dono dos meios de produção, não era dono de si próprio e de sua força de trabalho. Ou seja, o escravo não era sujeito de direitos. O que significava que o trabalho escravo possuía um estatuto sócio-histórico específico. Diferentemente do trabalhador assalariado, o escravo não era reconhecido como membro do corpo social. Era um pária societal não reconhecido como membro da espécie humana. Apesar de existir escravatura na Antiguidade, o modo de operação do escravismo era, de certo modo, exterior ao sócio-metabolismo das sociedades antigas (p.37).

Na passagem da sociedade de regime de trabalho escravocrata, para a ordem social competitiva, os negros escravizados, ao invés de terem seus direitos reparados pelos anos de opressão, agressão e morte, e também a garantia de alguma proteção, a partir do desenvolvimento do mercado de livre concorrência, receberam a socialização dos ônus pelo fim do regime escravocrata, que os jogou à própria sorte ${ }^{18}$. Segundo Fernandes (2008), na sua obra "a integração do negro na sociedade de classes $^{19 ",}$

historiadores, economistas, sociólogos, juristas e cientistas políticos, como ordem social competitiva" (FERNANDES, 2006, p. 179).

17 "A condição de trabalhador assalariado tornou-se uma condição humana, sendo elemento compositivo da normalidade social. Entretanto, ao surgir, em sociedades agrárias de atividade manufatureira-industrial de forma incipiente, o trabalho assalariado possuía o estigma da escravidão, tendo em vista que os trabalhadores assalariados, vulgo proletários, a plebe andrajosa, eram não apenas despossuídos dos meios de produção, mas de quaisquer direitos de cidadania. Eram uma "classe negativa" cujo movimento social tendia a "negar" a ordem burguesa (ALVES, 2012, p. 21).

18 "A grande questão poderia ser traduzida assim: o que fazer com o negro após a ruptura da polaridade senhor-escravo, presente em todas as dimensões da sociedade? Sim, porque é bom lembrar, mesmo os negros que já viviam em liberdade durante a escravidão, e que no século passado chegaram a ultrapassar o número de escravos, estavam sujeitos a numerosas restrições legais ou simplesmente impregnadas nos costumes de uma sociedade dominada por uma diminuta elite Branca". [...] "Quanto aos libertos, isto é, os negros alforriados, as restrições a eles eram ainda mais explicitas, constando de vários itens de leis que desta forma contrariavam a disposição da Constituição de 1824 em aceitá-los como cidadãos" (AZEVEDO, 1987, p. 34).

19 "Por razões não inteiramente evidentes, mas que terão mais a ver com dinâmicas disciplinares do que com a ordem do mundo, os estudos sobre escravidão fazem parte da genealogia de um ramo da investigação social que se poderia denominar "relações raciais", enquanto a investigação sobre a constituição da sociedade do trabalho no país encontrou seu momento inaugural na imigração européia. Não era para ser necessariamente assim, haja vista que um pensador eminente como 
os senhores foram eximidos da responsabilidade pela manutenção e segurança dos libertos, sem que o Estado, a Igreja ou outra qualquer instituição assumissem encargos especiais, que tivessem por objeto prepara-los para o novo regime de organização da vida e do trabalho (p. 29).

Desta forma, se antes os escravos morriam pelas chibatas e pelo trabalho forçado, agora, acusados de ingratidão pelos seus algozes, deveriam morrer por não terem trabalho ou pela sua inserção marginal e punitiva nas subocupações "fortalecendo de modo severo a tendência a confina-los a tarefas ou ocupações brutas, mal retribuídas e degradantes" (FERNANDES, 2008, 41).

Face a essa conjuntura, Fernandes (2008) assinala que,

diante do negro e do mulato se abrem duas escolhas irremediáveis, sem alternativas. Vedado o caminho da classificação econômica e social pela proletarização, restava-Ihes aceitar a incorporação gradual à escoria do operariado urbano em crescimento ou se abater penosamente, procurando no ócio dissimulado, na vagabundagem sistemática ou na criminalidade fortuita meios para salvar as aparências e a dignidade de "homem livre (FERNANDES, 2008, p.44).

Não identificamos como um acaso, a questão abolicionista e o consequente caminho do trabalho livre no Brasil. Por um lado, o abolicionismo "amadureceu e eclodiu como um processo histórico de condenação do 'antigo regime' em termos de interesses econômicos, valores sociais e ideais políticos da 'raça' dominante" (FERNANDES, 2008, p. 30); e, por outro, o sonho da constituição de uma nacionalidade brasileira fazia com que os emancipacionistas aderissem às soluções imigrantistas ${ }^{20}$. Assim,

Florestan Fernandes se interessou primeiramente pelo destino do ex-escravo, porque via em sua figura "marginal" (ou "desajustada") a expressão das mazelas da construção da ordem social competitiva, ou de nossa revolução burguesa" [...] "A razão para essa divisão disciplinar talvez resida em certo encadeamento de idéias defendido a partir dos anos 1950, segundo o qual o capitalismo moderno brasileiro teria surgido em São Paulo, com o que seria suficiente buscar ali suas raízes socioeconômicas. Isso mesmo depois de Celso Furtado ter demonstrado, nos mesmos anos 1950, que, se os capitais liberados pelo café estavam na origem da acumulação industrial paulista (e brasileira, por extensão), o capitalismo no Brasil era desigual, mas integrado, de modo que o destino do Nordeste ou da Amazônia não estava desconectado da dinâmica paulista. Como resultado, a vasta literatura sobre a consolidação do capitalismo e do mercado de trabalho no Brasil teve um inegável caráter "são-paulocêntrico" (CARDOSO, 2008, p. 72).

20 "Enquanto o estrangeiro via no trabalho assalariado um simples meio para iniciar "vida nova na pátria nova" calculando se libertar dessa condição o mais depressa possível, o negro e o mulato convertiam-no em um fim em si e para si mesmo, como se nele e por ele provassem a dignidade e a liberdade da pessoa humana" (FERNANDES, 2008, p. 45). 
a antiga preocupação com o destino dos ex-escravos e pobres livres foi praticamente sobrepujada pelo grande debate em torno do imigrante ideal ou do tipo racial mais adequado para purificar "a raça brasílica" e engendrar por fim uma identidade nacional (AZEVEDO, 1987, p. 37).

Tem-se, assim, a seguinte alteração de interesses: enquanto a mão de obra escravizada negra, no Brasil, servia de sustentáculo à economia e aos privilégios dos senhores brancos, ela era expropriada em toda a sua inteireza. Mas, a partir do momento em que os países capitalistas centrais iniciaram a sua rota para a abolição da escravatura e proibição do tráfico negreiro ${ }^{21}$, instituindo o livre mercado, o Brasil se viu pressionado a adotar formas mais profícuas de acumulação, na condição de nação dependente ${ }^{22}$. Contudo, apesar de o Brasil ser um dos últimos países a findar o seu regime escravocrata e aderir de forma lenta ${ }^{23}$ e tardia ao itinerário internacional do trabalho livre, esta adesão se fez da forma mais perversa possível, com a importação precária de mão-de-obra estrangeira.

Os trabalhadores nacionais que não estavam acostumados com as novas formas de produção, agora, além de desprotegidos ${ }^{24}$, teriam que disputar os postos precarizados de trabalho com os imigrantes; ou seja,

21 "Esse comércio de carne humana, gerador da diáspora negra que se abateu sobre mais de 12 milhões de vítimas, foi um dos mais importantes fatores a propiciar a chamada "acumulação primitiva" de capital que, no final do século XVIII, conduziria ao florescimento irresistível da Revolução Industrial e do capitalismo industrial moderno" (TRINDADE, 2011, p. 28).

22 "[...] a ordem social escravocrata e senhorial não se abriu facilmente aos requisitos econômicos, sociais, culturais e jurídico-políticos do capitalismo. Mesmo quando eles se incorporavam aos fundamentos legais daquela ordem, estavam condenados à ineficácia ou a um atendimento parcial e flutuante, de acordo com as conveniências econômicas dos estamentos senhoriais (largamente condicionadas e calibradas pelas estruturas econômicas, sociais e políticas herdadas do mundo colonial). Segundo, a emergência e o desenvolvimento da ordem social competitiva ocorreram paulatinamente, à medida que a desintegração da ordem social escravocrata e senhorial forneceu pontos de partida realmente consistentes para a reorganização das relações de produção e de mercado em bases genuinamente capitalistas. Sob esse aspecto, nem sempre as dificuldades à expansão interna do capitalismo procederam da "resistência à mudança" por parte dos estamentos senhoriais. É a própria situação "periférica" e "marginal" das economias capitalistas dependentes de origem colonial que explica tal fenômeno, com seus reflexos estruturais e dinâmicos sobre a ordem social competitiva correspondente" (FERNANDES, 2008, p. 181).

23 Vide Cardoso (2008).

24 "É relevante notar, no entanto, que os primeiros direitos sociais brasileiros foram instituídos pelo Código Comercial já em 1850. Este regulou a relação de trabalho exclusivamente urbana entre empregados e patrões na pratica comercial (então denominados de locadores e locatários de serviços de comercio), mas de forma abstrata, esvaziada de conteúdo social, o que lhe permitiu persistir no tempo, somente revogado pelo novo Código Civil de 2002. Contudo, instituiu direitos considerados precursores dos direitos getulistas" (SIMOES, 2013, p. 73-74). 
os ex-escravos tinham de optar, na quase totalidade, entre a reabsorção no sistema de produção, em condições substancialmente análogas às anteriores, e a degradação de sua situação econômica, incorporando-se à massa de desocupados e de semi-ocupados da economia de subsistência do lugar ou de outra região. Onde a produção atingia níveis altos, refletindo-se no padrão de crescimento econômico e de organização do trabalho, existiam reais possibilidades de criar um autêntico mercado de trabalho: aí, os ex-escravos tinham de concorrer com os chamados "trabalhadores nacionais" que constituíam um verdadeiro "exercito de reserva" [...] "e principalmente, com a mão de obra importada da Europa" (FERNANDES, 2008, p.31).

As aspirações pós-abolição de modernização e de maior geração de lucros, nesta transição de modos de produção, consolidou uma busca desenfreada pela substituição a qualquer preço do antigo agente do trabalho - os negros - pela mão de obra "perfeita" para o mercado de livre concorrência - os imigrantes. E mais, "segundo essa noção, um país em busca de um lugar na senda da modernidade deveria ser capitalista, industrial e urbano, demarcando sua posição no concerto das nações" (CARDOSO, 2008, p. 73).

Apesar de todo esse dilema vivenciado pelos negros pós-abolição, de pauperismo pela sua desproteção; de despreparo para o trabalho livre; e concorrência desigual com mão de obra estrangeira, na historiografia da constituição do capitalismo e da classe trabalhadora no Brasil, tem-se uma equivocada apreensão desta transição, a saber: de que ela só se deu com a inserção dessa mão de obra exterior, fazendo uma "[...] ruptura cabal entre o passado escravista e o novo ambiente competitivo. Tudo se [passando] como se a ordem escravocrata tivesse sido enterrada com a Abolição [...]" (CARDOSO, idem; ibidem).

Ao contrário dessa tentativa de mascarar ou mesmo apagar a constituição da sociabilidade capitalista por meio da exploração da mão de obra escravizada, nossa posição é de evidenciar que os dilemas vivenciados pelos negros na transição da sociedade escravista para a do trabalho "livre" e os impactos econômicos e sociais gerados pela mudança feita sem qualquer proteção para essa população, é um elemento evidente e processual que demonstra as especificidades e particularidades da constituição da classe trabalhadora brasileira e dos seus dilemas. Desta forma, concordando com Trindade (2011), 
escravismo colonial ao final do século XIX, o trabalho escravo ressurgiu, sob formas novas e igualmente infames, ao final do século $X X$ - justamente no momento em que as lutas operárias perdiam vigor ao redor do planeta. Mais uma vez, o capitalismo triunfante demonstra que consegue, sem qualquer aguilhão moral, combinar relações de trabalho "modernas" (assalariadas) com relações "atrasadas" (servis ou análogas à da escravidão). Trata-se do regurgitamento contemporâneo e feroz da velha lei capitalista do desenvolvimento desigual e combinado (TRINDADE, 2011, p.28).

Além disso, acreditamos que o surgimento do capitalismo no Brasil, país dependente, de origem colonial, se deu "antes da constituição da ordem social competitiva" (FERNANDES, 2008, p. 179), ou seja,

ele se defronta com estruturas econômicas, sociais e políticas elaboradas sob o regime colonial, apenas parcial e superficialmente ajustadas aos padrões capitalistas de vida econômica. $\mathrm{Na}$ fase de ruptura do regime colonial, tais estruturas alimentam e torna possível a adaptação aos dinamismos econômicos do mercado mundial, que na realidade desencadeiam e condicionam a transição, e servem de base à gradual formação de uma economia nacional "independente" (FERNANDES, 2008, p. 179).

Entretanto, compreendemos que a base de sustentação para o processo de acumulação capitalista no Brasil, com a extração da mais-valia, parte da inserção do trabalho "livre" e toda a sua forma de organização e exploração, por meio do trabalho assalariado e estranhado, que reúne todas as formas de opressão contidas nos modos de produção que o precederam. De acordo com Alves (2007)

É apenas com o capitalismo que tenderá a se constituir o mundo do trabalho propriamente dito (no singular), isto é, a forma social do trabalho sob a vigência do trabalho abstrato. Da multiplicidade de formas societais do trabalho estranhado, em maior ou menor proporção, que tendia a caracterizar a Antiguidade (do trabalho escravo ao trabalho artesanal, em suas múltiplas espécies), surge a unicidade das atividades de luta pela existência, a forma social do trabalho abstrato, a qual tenderia envolver todas as demais atividades prático-instrumentais num processo sistêmico de acumulação de valor (p. 76).

Esses processos históricos econômicos e sociais que visam a modernização e o desenvolvimento do capitalismo nacional têm diversos elementos que constituem o processo da "revolução burguesa" no Brasil. A esse respeito Fernandes (2008), afirma que, 
O esboroamento final da sociedade de castas e o processo de elaboração da ordem social competitiva se ligam, complexamente, às condições de desenvolvimento da empresa agrária - "a grande fazenda de café" - nas zonas em crescimento econômico, demográfico e social acelerado. Por isso, ao mesmo tempo que a dinamização final da crise do antigo regime veio do campo, dele também partiu a contenção ativa das tendências de reintegração da ordem social, desencadeadas ou inerentes a essa mesma crise (p. 5960).

Referindo-se a esse conceito de revolução burguesa, Fernandes (2008), afirma que esta "denota um conjunto de transformações econômicas, tecnológicas, sociais, psico culturais e políticas, que só se realizam quando o desenvolvimento capitalista atinge clímax de sua evolução industrial” (p. 239).

É necessário destacar que na análise da formação da burguesia no Brasil, conforme Fernandes (2006), há duas tendências que são demasiadamente "impróprias e extravagantes": por um lado, há a construção de que "o burguês" e a "burguesia" teriam surgido e florescido com a implantação e a expansão da grande lavoura exportadora" (p. 32); e por outro lado, "ambos não teriam jamais existido no Brasil, como uma paisagem em que não aparece nem o Castelo nem o Burgo, evidências que sugeririam, de imediato, ter nascido no Brasil" (p.32).

Segundo Fernandes (2006), não se pode associar o senhor de engenho ao burguês, nem tampouco a aristocracia agrária à burguesia, tendo em vista que, em relação ao senhor de engenho, as riquezas encontradas e apropriadas deveriam ser complementadas ou substituídas num processo simplista e colonial por meio da mão de obra escrava. Sendo assim, "ele ocupava uma posição marginal no processo de mercantilização da produção agrária e não era nem poderia ser o antecessor do empresário moderno" (p.32). Além disto, o excedente econômico apropriado, não se relaciona com o "lucro" encontrado contemporaneamente, caracterizando um "contrasenso pretender que a história da burguesia emerge da colonização" (p. 33).

A segunda construção, que afirma a inexistência da burguesia no Brasil, segundo o autor, é frágil pelo seu campo de abrangência histórica, incorrendo no erro de considerar histórico apenas o que acontece no presente, dissociando a dinâmica particular dos eventos históricos de cada lugar, tempo demarcado e dos padrões de sociabilidade comuns e particulares. Sendo assim, ele destaca, 
o que é ou não histórico determina-se no nível do significado ou da importância que certa ocorrência (ação, processo, acontecimento etc.) possua para dada coletividade, empenhada em manter, em renovar ou em substituir o padrão de civilização vigente (FERNANDES, 2006, p.33).

No Brasil, o que se deve analisar são os rumos econômicos, sociais e políticos que se pretendeu materializar após a independência, para a inserção no "mundo ocidental moderno", fugindo de uma fundamentação que possa estar atrelada a eventos naturais e exóticos para explicar o surgimento da burguesia. Portanto,

à luz de tais argumentos, seria ilógico negar a existência do "burguês" e da burguesia no Brasil. Poder-se-ia dizer, no máximo, que se trata de entidades que aqui aparecem tardiamente, segundo um curso marcadamente distinto do que foi seguido na evolução da Europa, mas, dentro de tendências que prefiguram funções e destinos sociais análogos tanto para o tipo de personalidade quanto para o tipo de formação social (FERNANDES, 2006, p.34).

Porém, é interessante notar que esses rumos assumidos pelo Brasil, para a sua inserção no mundo ocidental moderno, ou seja, no modo de produção e acumulação capitalista, seria impensável sem a presença de um Estado burguês que legitimasse tanto a dominação burguesa, como a transição para um sistema de manutenção de privilégios ${ }^{25}$. Para Fernandes (2006),

ao contrário de outras burguesias, que forjaram instituições próprias de poder especificamente social e só usaram o Estado para arranjos mais complicados e específicos, a nossa burguesia converge para o Estado e faz sua unificação no plano político, antes de converter a dominação socioeconômica no que Weber entendia como "poder político indireto" (p. 240).

Nesse sentido, torna-se importante observar a continuidade das mudanças referentes ao processo de aprofundamento do modo de produção capitalista e

25 "Assim, foram decisivos processos como a ruptura com a homogeneidade da aristocracia agrária, ao lado do surgimento de novos agentes econômicos, sob a pressão da divisão do trabalho, na direção da construção de uma nova sociedade nacional. Contudo, esse movimento é marcado pela ausência do compromisso com qualquer defesa mais contundente dos direitos do cidadão por parte das elites econômico-politicas, o que é uma marca indelével da nossa formação, fato que é fundamental para pensar a configuração da política social no Brasil" (BERING e BOSCHETTI,2011, p. 73). 
também ao sentido e ao lugar desse Estado, burguês e contraditório, que tem como fundamento ao mesmo tempo a manutenção de privilégios e a garantia de direitos.

\subsection{Breves considerações sobre o trabalho assalariado sob o jugo do capital.}

Como já vimos apresentando, os dilemas do trabalho assalariado, mais especificamente sua condição degradante, com a emergência da dinâmica do modo de produção capitalista, assume centralidade, sendo resultado da contradição materializada na apropriação privada dos instrumentos e dos lucros da produção e da socialização dos ônus engendrados principalmente em tempos de crise do capital, tornando-se uma equação essencial neste modo de produção. Nessa equação o capital se destaca por ter como pressuposto a dominação e por ser "um modo de controle do metabolismo social que instaura formas históricas de intercâmbio produtivo dos seres humanos com a natureza e entre si qualitativamente novas, radicalmente incomparáveis [...]" (ALVES, 2007, p. 32).

Dialogando com essas afirmações, Guiraldelli (2010), afirma que,

desde a consolidação do capitalismo, com a Revolução Industrial do século XVIII iniciada na Inglaterra, os processos de trabalho assumiram novas formatações diante do fenômeno da industrialização e da urbanização. Nesse marco histórico, o capitalismo se consolida fundado em quatro pilares: a propriedade privada dos meios de produção, a economia baseada na produção industrial, o trabalho sob o regime de assalariamento e a constituição de duas classes sociais com interesses antagônicos - burguesia e proletariado. A partir de então, o capitalismo se desenvolveu pela lógica da livre concorrência e desencadeou concentração e centralização da produção, estimulando o surgimento da fase monopolista, também denominada imperialista, ou seja, um estágio superior do sistema produtor de mercadorias (p. 87).

A relação de dominação do capital sobre o trabalho se intensifica cada vez mais com o protagonismo da mundialização do capital e com a expansão imperialista 26 deste, sob a forma de capital financeiro, por todas as esferas da vida social ${ }^{27}$. Em

26 “O imperialismo é o capitalismo chegado a uma fase de desenvolvimento onde se afirma a dominação dos monopólios e do capital financeiro [fusão do capital bancário e do capital industrial], onde a exportação dos capitais adquiriu uma importância de primeiro plano, onde começou a partilha do mundo entre os trustes internacionais e onde se pôs termo à partilha de todo o território do globo, entre as maiores potências capitalistas" (LENIN, 1979, p. 88).

27 Segundo lamamoto (2007): "Na busca incessante e ilimitada do aumento exponencial da riqueza quantitativa - o crescimento do valor pelo valor -, os investimentos financeiros tornam a relação 
relação a essa invasão do capital nas esferas do trabalho e na vida social, Antunes (2006), esclarece que,

A década de 1980 presenciou, nos países de capitalismo avançado, profundas transformações no mundo do trabalho, nas suas formas de inserção na estrutura produtiva, nas formas de representação sindical e política. Foram tão intensas as modificações, que se pode mesmo afirmar que a classe-que-vive-do-trabalho sofreu a mais aguda crise deste século, que atingiu não só a sua materialidade, mas teve profundas repercussões na sua subjetividade e, no íntimo interrelacionamento destes níveis, afetou a sua forma de ser (p. 23).

Não por acaso, a financeirização do capital, domina as esferas intra e extra trabalho e também impõe a esse trabalho adequações para se manter rentável e pouco dispendioso, no sentido de poupar investimentos e extrair o máximo de maisvalia que a força de trabalho é capaz de produzir. Para alcançar seus objetivos, o capital, por meio da fadiga da classe que vive do seu trabalho ${ }^{28}$, imprime uma jornada laboral que tem como fundamento: precarizar e super-explorar.

Trabalho e mais trabalho (precário, instável, degradante)! Eis a síntese da vida humana no modo de produção capitalista. É preocupante, não a centralidade do trabalho ontológico, como demonstrado em capitulo anterior, na vida humana, tendo em vista que trabalhar é a condição primeira de transformação do homem natural em social; mas os rumos que este trabalho assumiu foi o da de jornada prolongada, de flexibilização dos contratos, de retirada de direitos e de degradação crescente da vida. Marx (1985), confirma que,

\begin{abstract}
A produção capitalista, que é essencialmente produção de mais-valia, absorção de mais-trabalho, produz, portanto, com o prolongamento da jornada de trabalho não apenas a atrofia da força de trabalho, a qual é roubada de suas condições normais, morais e físicas, de desenvolvimento e atividade. Ela produz a exaustão prematura e o aniquilamento da própria força de trabalho. Ela prolonga o tempo de produção do trabalhador num prazo determinado mediante 0 encurtamento de seu tempo de vida (MARX, 1985, p.212).
\end{abstract}

social do capital com o trabalho aparentemente invisível. Intensifica-se a investida contra a organização coletiva de todos aqueles que destituídos de propriedade, dependem de um lugar nesse mercado (cada dia mais restrito) para produzir o equivalente de seus meios de vida" (IAMAMOTO, 2007, p. 21).

${ }^{28}$ De acordo com Antunes e Alves (2004), "a classe trabalhadora hoje compreende a totalidade dos assalariados, homens e mulheres que vivem da venda da sua força de trabalho - a classe-que-vivedo-trabalho" (p. 336). 
A jornada de trabalho ${ }^{29}$, seu tempo, suas condições objetivas e subjetivas, pode dimensionar o grau de servidão a que os trabalhadores estão submetidos, tendo em vista que para a produção da mais-valia a jornada normal, não é suficiente. Segundo Marx (1985), essa jornada de trabalho "compreende diariamente as 24 horas completas, depois de descontar as poucas horas de descanso, sem as quais a força de trabalho fica totalmente impossibilitada de realizar novamente sua tarefa" (MARX, 1985, p.211).

O tempo de trabalho tem vinculação direta com o valor, ou com a formação do valor, tendo em vista que "o valor é o tempo de trabalho consumido de acordo com os padrões médios vigentes na sociedade" (DAL ROSSO, p.54), e o processo de acumulação necessita de forma crescente do tempo de trabalho. $O$ alongamento do tempo de trabalho, desta forma, é mais que necessário; é vital para o processo de acumulação.

De acordo com Dal Rosso (2008), esse alongamento é "um processo historicamente constatável e atingiu a sua dimensão maior na primeira Revolução Industrial em quase todos os países do mundo" (p. 55). Observaremos no capitulo 3 , que para a constituição das primeiras leis que tendiam a barrar o processo de destruição da vida dos trabalhadores nas fabricas, foram necessárias estratégias de luta dessa classe, tendo em vista que,

chegou um momento em que o alongamento da jornada atingiu um ponto intransponível, seu teto. Tal era a destruição física dos empregados que a voz da população se fez sentir e os governos começaram a aprovar leis que estabeleciam controles sobre a duração do serviço legalmente aceitável e sobre a duração do tempo de trabalho para algumas categorias especificas, como as mulheres, as crianças e os adolescentes. Com tal tipo de legislação, a via da acumulação de riquezas por meio da produção da mais-valia absoluta foi impedida para os capitalistas, para os gerentes de atividades estatais e para os pequenos produtores de mercadorias. Mas, a torneira da acumulação enquanto tal não foi fechada [...] passaram a buscar a acumulação por meio do mecanismo de tornar o trabalho mais intenso (p. 55).

Na contemporaneidade, a degradação do trabalho é multifacetada. Como já mencionado, o capital financeiro, portador de juros, impõe para sua manutenção e

29 "Parte da jornada de trabalho é trabalho necessário, cobrindo as necessidades de reprodução da força de trabalho na forma de salários; outra parte é trabalho excedente, ou seja, mais-valia, valor acrescentado" (BEHRING, 2010, p. 17). 
maior valoração o rompimento com o padrão fordista/keynesiano; ou seja, com o trabalho regulamentado e estável, apontando como saída a flexibilização ou a volatilidade dos contratos de trabalho.

Segundo Lopes (2011), o papel decisivo do "capital-dinheiro sob a face de capital a juros e a expansão do sistema de credito, a partir da década de 1970, impulsionaram a acumulação financeira e a fusão de interesses entre o capital financeiro e a indústria, com o apoio decisivo do Estado" (p. 82). Assim, além da rapidez da quebra dos contratos de trabalho (tornando contratos e trabalhadores descartáveis), esta forma de capital invade, para além da esfera do trabalho, todas as outras formas e relações sociais no modo de produção capitalista, objetificando-as e tornando-as meios passíveis de trocas e obtenção de lucros. Dessa forma,

em plena eclosão da mais recente crise global, a partir de 2007/2008, esse quadro se intensificou ainda mais e nos faz presenciar uma corrosão ainda maior do trabalho contratado e regulamentado, que foi dominante ao longo do século XX, de matriz tayloriano-fordista, e que vem sendo substituído pelos mais distintos e diversificados modos de terceirização, informalidade e precarização, ampliando os mecanismos de extração do sobretrabalho em tempo cada vez menor (ANTUNES E DRUCK, 2015, p. 214).

Nesse debate, em que a crise do sistema do capital tem centralidade, 0 período final dos anos 1970 constitui um marco referencial, tendo em vista a falência do padrão keynesiano-fordista e a eclosão da referida crise, de caráter estrutural. Outros dilemas também surgem com o fim do padrão keynesiano-fordista como "[...] a liberalização dos fluxos de câmbio, a abertura do mercado de créditos aos operadores estrangeiros, a abertura da Bolsa às empresas estrangeiras etc." (CHESNAIS, 1996, p. 264).

É nesse processo que critérios individualistas erigem e fundamentam as relações sociais contemporâneas; ou seja, "trata-se do que passou a ser chamado de "novo" ou neoliberalismo, por ser uma versão contemporânea do liberalismo clássico "que sempre primou pela privatização dos bens e serviços públicos e pelo individualismo possessivo, cuja melhor expressão ideológica é o empreendedorismo" (PEREIRA-PEREIRA, 2015, p. 462). 
Em analogia às relações sociais que circundam o âmbito da produção, é interessante também observar os dilemas gerados a partir da subjugação do trabalho pelo capital na contemporaneidade e o processo de geração estrutural da desigualdade. Neste cenário, o poder econômico se sobrepõe a todo e qualquer campo social, corroborando com as aspirações sociais que supervalorizam o "ter que trabalhar" e o "ter sucesso" a partir desse trabalho. Nessa concepção, parafraseando Barbalet (1989), "[...] a experiência humana tem mostrado que quem possui poder econômico também controla o governo e a lei" (p. 73). E, com isso, cria-se a ilusão de mobilidade social, econômica e política.

O que não se percebe, é que, com a a dominação dessa ética do trabalho, ocorre, por um lado, mais fadiga e sofrimento, apesar da sensação de independência que $o$ assalariamento produz no sujeito que vende a sua força de trabalho e, por outro lado, aumento despoporcional do lucro ao capital. Segundo Wood (2006),

o poder do capitalista de se apropriar da mais-valia dos trabalhadores não depende de privilegio jurídico nem de condição cívica, mas, do fato de os trabalhadores não possuírem propriedade, o que os obriga a trocar sua força de trabalho por um salário para ter acesso aos meios de trabalho e de subsistência. Os trabalhadores estão sujeitos tanto ao poder do capital quanto aos imperativos da competição e maximização dos lucros (p. 173).

Nessa perspectiva é necessário também fazer uma análise sobre o lugar e o papel do Estado no processo de legitimação da exploração do capital, mas, também, como garante de direitos, já que, se ele "limita a desimpedida ação individual pode garantir direitos sociais, visto que a sociedade lhe confere poderes exclusivos para 0 exercício dessa garantia" (PEREIRA-PEREIRA, 2011, p. 99).

\subsection{O Estado "antissocial" do pró-trabalho}


Pensar a constituição do Estado ${ }^{30}$ é vital para entender as transformações societárias que se materializaram no percurso histórico da sociedade brasileira ${ }^{31}$. Suas particularidades econômico-político e sociais, antes de assumirem contornos próprios, tendo em vista a característica do capitalismo brasileiro, periférico e dependente, sofrem influências da dinâmica externa do processo de valorização impostas pelos países de capitalismo central. Como afirma Paula (2013)

a formação social brasileira não se processa alheia à universalidade do capitalismo, e nem mesmo se absteve da criação de traços particulares e singulares que distinguiram de outras formações congêneres. Em outros termos: Se as regras gerais do sistema de produção generalizada de mercadorias permaneceram presentes na constituição da sociedade capitalista brasileira, do mesmo modo penetram as condições históricas objetivas dadas preliminarmente, plasmando em momentos de síntese, não apenas a sua universalidade como também a formação e conformação do Estado burguês brasileiro que, desde a sua gênese até a atualidade, funciona como agente das "revoluções passivas" que marcam sua história ( $p$. 28-29).

São essas aspirações burguesas que, com a legitimação do Estado, impõem às relações sociais no modo de produção capitalista a uniformização dos ideais pautados no consumo e no mercado. Pensar, nesse contexto, num Estado amparado no privilegiamento de direitos sociais desmercadorizados que se contraponham aos ditames da logica capitalista de exploração, e na fuga da lógica competitiva, é de certa medida, um devaneio.

Apesar disto, o caráter "social ou antissocial" do Estado, traz consigo uma série de determinações prévias que influem na sua ação ou omissão. Fato este que torna, "um equívoco considerá-lo um simples instrumento ou mecanismo de reprodução das

${ }^{30}$ Apesar da nossa incursão pelos domínios do Estado liberal, dominado pelo mercado, é necessário evidenciar que, para nós, o Estado não se constitui sem os antagonismos das classes que compõem a sociedade. Conforme Poulantzas (1977), "tomar o Estado como a condensação de uma relação de força entre classes e frações de classe tal como se exprimem, de modo especifico, no seio do Estado, significa que o Estado é constituído-atravessado em toda parte pelas contradições de classe. Isto significa que uma instituição, o Estado, destinada a reproduzir as divisões de classe não é, não pode jamais ser, como o consideram as concepções do Estado-coisa e do Estado-sujeito, um bloco monolítico sem fissuras, mas é ele mesmo, com sua própria estrutura, dividido" (p. 23).

31 "História baseada no escambo e escravidão, no colonialismo e imperialismo, na urbanização e industrialização, por meio da qual se dá, inicialmente, a formação da sociedade de castas, e, posteriormente, da sociedade de classes. Uma história atravessada por lutas sociais da maior importância, desde as revoltas de comunidades indígenas contra os colonizadores às lutas contra o regime de trabalho escravo. História essa que, no século $x x$, desenvolve-se com as lutas de trabalhadores do campo e da cidade pela conquista de direitos sociais ou pela transformação das estruturas sociais" (IANNI, 1996, p. 25). 
relações de produção ou uma instituição funcional apenas ao capital" (PEREIRAPEREIRA, 2009, p. 218). Por isso, é mais que necessário considerar a relação contraditória que perpassa sua materialidade no real, de ao mesmo tempo negar e conceder. Ou como afirma Pereira (2009),

tem-se, assim, nesse misto de coerção e proteção que permeia, sob diferentes formas, intensidades e complexidades, todos os tipos de Estado, a presença insofismável da contradição, isto é: da contradição como fator responsável pela impossibilidade de o poder estatal ser exclusivamente bom ou mal, positivo ou negativo, em qualquer contexto e momento histórico. Na verdade, o Estado, assim como a política, pode ser considerado positivo e negativo ao mesmo tempo, dependendo da dinâmica estrutural em vigência e da correlação de forças (PEREIRA-PEREIRA, 2009, p. 210).

Com efeito, na historiografia das políticas sociais, percebe-se que quanto mais há a liberalização do Estado no que tange às relações de produção em sociedade, e maior envolvimento com o mercado, muitas vezes transformando-se em um só ente, mais este tende a privilegiar a concepção individualista, camuflada de liberdade ${ }^{32}$, da auto-satisfação provida pelos rendimentos do trabalho assalariado, configurando-se assim em um Estado que seria "pró-trabalho" e "antissocial"

Jessop (2013), faz uma distinção interessante em relação ao Estado ou regime de bem-estar pró-trabalho, subdividindo-o em shumpeteriano e ricardiano. O regime pró-trabalho shumpeteriano, que é influenciado pelas concepções políticoeconômicas de Joseph Shumpeter, baseia-se em uma economia ligada ao conhecimento e à ação empreendedora dos agentes econômicos. Jessop denomina "Regime Pós-Nacional Schumpeteriano Pró-Trabalho (RPNSPT)" que "pode ser apresentado da mesma forma que o Estado Nacional de Bem-Estar Keynesiano" (JESSOP, 2013, p. 271) que o precedeu. E esclarece que

\footnotetext{
32 "A liberdade a que se referiram os pioneiros da tradição liberal é a que se faculta aos indivíduos no plano formal. É a garantia de que os cidadãos podem agir de modo desimpedido na conformação de seus interesses particulares. Essa noção de liberdade, aqui muito sumarizada, baliza a construção do Liberalismo como seu desdobramento no campo jurídico-político de ordenamento das sociedades modernas e democráticas que surgem, em processo, desde o final do século XVI [...]. Contudo, a clareza acerca do seu potencial e significado torna-se um ideal hegemônico, na Europa de século XVIII, antes, durante e depois da irrupção da Revolução Francesa. Mas, depois dela é que se alastra não mais como ideal, mas, como experiência real” (PAULA, 2013, p. 129).
} 
- Regime Schumpterinano é Pró-Trabalho (workfariano) porque subordina a política social às demandas por flexibilidade e inserção no mercado de trabalho, bem como por competição econômica. Isso implica exercer pressão sobre o salário social como custo de produção internacional; mas, devido aos limites econômicos e políticos dos cortes nos gastos do bem-estar, ele se investe especialmente na refuncionalização do Estado de Bem-Estar para servir aos interesses econômicos. O Estado também tenta criar sujeitos para atuarem como parceiros de uma economia inovadora, baseada no conhecimento, empreendedora e flexível típica do Regime Schumpetriano do PróTrabalho autossuficiente, autônomo e empoderado (p. 272).

Já o regime ricardiano, segundo Jessop (2013), baseia-se em uma consistente mudança no padrão neoliberal, caracterizando-se pela adesão de seis aspectos, quais sejam:

(1) liberalização para promover a competição livre; (2) desregulação para reduzir o papel da lei e do Estado rígidos; (3) privatização para vender o setor público frequentemente abaixo do valor de mercado; (4) representações do mercado no setor público residual para promover uma quasi-mercantilização; (5) internacionalização para liberar grande número de fluxos econômicos para dentro e fora das economias nacionais, com vista a: reduzir atritos na economia mundial, generalizar pressões competitivas e, supostamente, transferir melhores práticas - o que também pode significar promoção de um nivelamento por baixo; (6) reduções de taxas diretas para impulsionar a compra por parte do consumidor e, principalmente, aumentar os lucros líquidos, descontados os impostos de empresas e instituições financeiras (p. 273).

Essas distinções, apesar de serem demarcadas por momentos históricos próprios, se articulam quando está em jogo o mercado, as "liberdades e a proteção social. Assim, se, por um lado, o regime shumpeteriano, busca a flexibilização, privatização das políticas sociais destacando-se como incentivador da primazia do mercado de trabalho e da competição, o regime ricardiano, subordina ou imbrica a noção de liberdade à de livre concorrência e mercantilização ampliada, que constitui a máxima da ética capitalista do trabalho. É o que Pereira-Pereira e Siqueira (2014) traduzem na seguinte reflexão:

o direito à proteção contra os abusos do trabalho assalariado tem se esvanecido porque a conquista do trabalho em si, ou como simples meio de obtenção de rendimentos econômicos, tornou-se essencial. Poder trabalhar, em conformidade com a lógica capitalista, inclusive na concepção de setores ditos progressistas, transformou-se no 
melhor ganho político e maior "direito de cidadania" conquistado pelos que foram obrigados a depender das políticas passivas de bem-estar social (leia-se incondicionais). Essa é a ilusão de corte schumpeteriano, num primeiro momento de predomínio do modelo monetarista de desenvolvimento capitalista, e de corte ricardiano (tributário da economia política clássica) da atual idade de bronze da política social, cujo lema é o bem-estar humano por meio do trabalho remunerado; ou do que foi concebido nos Estados Unidos desde os anos 1970, que é a substituição progressiva e perversa do welfare pelo workfare (p. 459).

Nesta relação entre Estado e sociedade, materializa-se um "padrão de mercado" que, conforme Polanyi (2000), influi e molda as relações sociais. Isso significa, segundo ele, "nada menos [que], dirigir a sociedade como se fosse um acessório do mercado"; e, portanto, "em vez de a economia estar embutida nas relações sociais, são as relações sociais que estão embutidas no sistema econômico" (p. 77).

Está aí a dimensão contraditória das ações do Estado capitalista projetada nas políticas de proteção social, que, ao se redefinirem em acordo com as exigências do mercado, fragilizam e restringem o acesso e o público dessas políticas, ao combate superficial da pobreza e estimulam a construção de um senso-comum em torno da crença de que só por meio do trabalho assalariado haverá mobilidade social, "sucesso" e bem-estar meritório.

Segundo Pereira-Pereira (2013) fazem parte desse "mantra" liberal, apreendido massivamente pela sociedade, a concepção de que

a) o indivíduo deve ser incentivado a autossatisfazer as suas necessidades; b) é da natureza humana o ímpeto para maximizar o prazer por meio da competição e do consumo constante; [e] c) não há instituição mais eficiente, eficaz e democrática de provisão do bem-estar humano do que o mercado (p. 640).

Volta e meia, levanta-se, no terreno do senso comum, a indagação da necessidade ou não do Estado prover proteção social à sociedade, especialmente aos mais pobres. Se observarmos, este questionamento toma corpo de tempos em tempos, principalmente em épocas de retração da economia em contexto mundial e nas quais o lucro capitalista se vê ameaçado. Não à toa, os velhos boatos de 
"malvadeza" da interferência do Estado nos assuntos "individuais" ou na "liberdade" dos indivíduos, bem como de malefícios da intervenção estatal no percurso supostamente autorregulável da economia, reaparecem em rodas políticas liberais e conservadoras.

Segundo Bonavides (1961), na perspectiva liberal o Estado "foi sempre o fantasma que atemorizou o indivíduo. $O$ poder, de que não pode prescindir o ordenamento estatal, aparece, de início, na moderna teoria constitucional como o maior inimigo da liberdade (p. 2). Nessa conjuntura,

o indivíduo, titular de direitos inatos, exercê-los-ia na sociedade, que aparece como ordem positiva frente ao Estado, ou seja, frente ao negativum dessa liberdade que, por isso mesmo, surge na teoria jusnaturalista rodeado de limitações, indispensáveis à garantia do círculo em que se projeta soberana e inviolável a majestade do indivíduo (p. 2-3).

Por conseguinte, o culto à ausência do Estado no que tange o mundo social, a partir da ideologia liberal, desempenha papel ativo quando se pensa na satisfação de determinados aspectos da vida em sociedade, pois o mercado teria "todas as capacidades de resolver essas questões", por meio da autorregulação da economia ou pelo investimento do tempo de trabalho assalariado na produção de bens.

Tendo em vista dessas tensões, podemos inferir que uma sociedade que se funda nos privilégios de alguns, em detrimento do direito de outros, mediante a exploração do trabalho, como a brasileira, a lógica da liberdade individual (leia-se individualização da responsabilidade pela manutenção da vida, ou da livre concorrência econômica) soa bastante antidemocrática, com tendência a reproduzir mais punição e desigualdades sociais. 


\section{CAPITULO 3}

\section{ASSISTÊNCIA SOCIAL E TRABALHO: UMA EQUAÇÃO PERSISTENTE, EMBORA SUTIL, NO CAPITALISMO}

O capitulo que se apresenta demonstra a relação contraditória que se estabelece entre Trabalho e Assistência Social no desenvolvimento da sociedade capitalista, relação de sintonia e tensão, por vezes sutil, que perdura no debate sobre: quem e de que forma proteger?

Na raiz deste debate, que por sua inserção no real também é contraditória, está materializada a luta de classes, a subjugação do trabalho pelo capital, as estratégias burguesas de manutenção de seus privilégios por meio da ideologia da meritocracia e do condicionamento à ética de qualquer trabalho e o desincentivo estatal para a proteção social, fundamentando uma lógica regressiva e restritiva às políticas que se proponham questionar os abusos perpetrados pelo Trabalho assalariado e degradante. Apesar de fazermos um movimento para demonstrar a tendência dessa lógica em alguns países, que é fruto do desenvolvimento e da extraterritorialidade da globalização do capital, nossa apreensão mais densa será a partir da análise da realidade brasileira, demonstrando as contradições presentes no processo de institucionalização da assistência social por meio do seu marco regulatório.

\subsection{Tensão e Sintonia entre assistência social e trabalho assalariado: análise histórico - critica.}

Os estudos sobre o Sistema de Proteção Social brasileiro têm demonstrado historicamente o padrão social de legitimação da proteção social ligada ao bem-estar ocupacional, ou seja, à iniciativa de proteger os trabalhadores assalariados que, através da venda da sua força de trabalho, proporcionam a expansão e a acumulação do capital. 
A busca incansável por qualquer trabalho fortaleceu uma cultura política ou mesmo uma ética capitalista do trabalho, que culpabiliza e individualiza o "insucesso", como o desemprego e a decorrente dificuldade de autossustentação de cada um. Mas, é importante que haja o questionamento e o conhecimento sobre a quem se destina a punição e a desproteção por esta dita "incapacidade" de cunho moral ou mesmo preguiça em relação ao trabalho? Nesta sociedade dividida em classes, é a classe trabalhadora que sofre as punições referenciadas no culto ao trabalho, gerador de mais valia, de que não detém meios de produção e nem alternativas à venda de sua força trabalho.

Apesar dessa ausência de meios de produção e da injusta remuneração de seu trabalho, os trabalhadores quando inseridos no mercado laboral capitalista são também responsáveis minimamente pelo processo de circulação do dinheiro, como consumidores. Não é por acaso que a busca incessante deste modo de produção, principalmente na sua versão liberal, é a expectativa da formação e desenvolvimento de mercados autorregulados, sob a égide da liberdade da iniciativa privada.

Polany (2000), ao se referir à economia de mercado e às suas estratégias, salienta que:

\begin{abstract}
uma economia desse tipo se origina da expectativa de que os seres humanos se comportem de maneira tal a atingir o máximo de ganhos monetários. Ela pressupõe mercados nos quais o fornecimento dos bens disponíveis (incluindo serviços) a um preço definido igualarão a demanda a esse mesmo preço. Pressupõe também a presença do dinheiro, que funciona como poder de compra nas mãos de seus possuidores. (p.89).
\end{abstract}

Pode-se, por conseguinte, afirmar que a proteção social sob o comando liberal, adota mecanismos mercantis e medidas de maximização de sua serventia às necessidades de lucro do capital; bem como a incorporação "da ética utilitarista e meritocrática capitalista, que exige: trabalho como sacrifício, cobrança de contrapartidas e regência da lógica da troca contratual" (PEREIRA-PEREIRA, p. 2013, p. 642).

A pregação moralista transmitida pela ideologia burguesa do trabalho remunerado, tornou-se tão sedutora e consensual que esse trabalho difundiu-se não apenas como um dever ético, mas também um direito do cidadão, como se houvesse 
apenas um tipo trabalho - formador do caráter e sem características aparentes de servidão. Weber (2013), nas suas análises acerca da ética protestante e o espírito do capitalismo concebe uma uniformização do trabalho, afirmando que:

Esta ideia peculiar, que hoje nos é tão familiar, mas na realidade tão pouco óbvia, da carreira como um dever, é o que há de mais característico na ética social da cultura capitalista, e é, em certo sentido, a sua base fundamental. É uma obrigação que o indivíduo deve sentir, e de fato sente, em relação ao conteúdo de sua atividade profissional, pouco importando no que ela consiste, e particularmente nem se ela se apresenta imediatamente como a utilização de suas forças pessoais ou apenas de suas posses materiais (como capital) (p.57).

Se concordássemos com esta analise weberiana, estaríamos negando que esta sociedade é constituída por antagonismos de classes - a dos trabalhadores (não possuidores dos meios de produção) que têm de aceitar qualquer trabalho para sua subsistência e a dos capitalistas (possuidores dos meios de produção) e, como tais, compradores de força de trabalho. Negar esta constituição contraditória seria cometer um equívoco na análise dessa realidade, limitando-nos aos aspectos fenomênicos de algo que é essencialmente dinâmico e complexo.

Na contramão das afirmações weberianas, da uniformização do trabalho, Marx (1985), ao se referir à divisão social do trabalho e a sua jornada, é profícuo na demonstração da "avidez [do capital] por mais trabalho", dissertando que,

o capital não inventou o mais-trabalho. Onde quer que parte da sociedade possua o monopólio dos meios de produção, o trabalhador, livre ou não, tem de adicionar ao tempo de trabalho necessário à sua autoconservação um tempo de trabalho excedente destinado a produzir os meios de subsistência para o proprietário dos meios de produção [...] Trabalho forçado até a morte é aqui a forma oficial de sobretrabalho (p. 190).

Sendo assim, torna-se equivocada a tentativa de uniformização do trabalho no modo de produção capitalista, pois se, por um lado, há acumulo de riquezas, por outro, o trabalho fornece sofrimento e fadiga. É nesse entendimento que a proteção social é encarada pelos liberais como uma despesa desnecessária e que tem fortes incentivos à ociosidade da classe trabalhadora, pois nada seria mais qualificado e digno que a 
proteção do livre mercado e do trabalho assalariado. Confirmando esta tendência, Pereira-Pereira (2013), contribui ao afirmar que,

efetivamente, na retórica que louva o labor como atividade dignificante, o mercado livre, o individualismo possessivo; o mérito como antítese do direito e a ética hedonista do prazer imediato e fugaz, o comprometimento do poder público, com a garantia dos direitos sociais, torna-se desacreditado. Não porque o capital independa do Estado para garantir o trabalho assalariado e a manutenção de um exército de reserva, que lhe são essenciais. Mas porque a linguagem e a cultura dos direitos sociais, diferentemente dos direitos individuais, trazem para o âmbito da exploração do trabalho assalariado o questionamento de seus abusos (p.641).

Com esse movimento, proporcionado pela proteção social, ou melhor, de fornecer a manutenção da mão de obra para de trabalho assalariado, e, principalmente, de naturalizar os abusos do trabalho assalariado, sobressaem duas óticas antagônicas que devem ser consideradas: do lado dos capitalistas, caso haja a prevalência de direitos que não estejam estritamente vinculados ao trabalho, estes desencentivarão o ato de trabalhar e potencializarão um cenário em que se estabeleça determinados freios para uma maior exploração, bem como a morosidade no acumulo de riquezas.

Já no que concerne aos trabalhadores, essa lógica desdobra-se em duas direções: na primeira, a ideologia burguesa promove a construção de um consenso entre classes, consolidando na opinião pública a importância de se valorizar qualquer trabalho (não importa se escravo, servil ou precário) e rebaixa quem demanda por proteção social do Estado à categoria de subcidadania e "falha moral". Mas, por outro lado, ao se deparar com os efeitos deletérios deste trabalho assalariado, a luta por direitos sociais que protejam o trabalhador contra os abusos dele decorrentes, possibilitando a consciência e mobilização da classe obreira.

Marx (1996) na seção intitulada - "Legislação sanguinária contra os expropriados desde o final do século XV. Leis para o rebaixamento dos salários" demonstra como os trabalhadores retirados do seu processo costumeiro de reprodução foram tratados pelas legislações contra a vagabundagem. Segundo ele: 
[os trabalhadores] se converteram em massas de esmoleiros, assaltantes, vagabundos, em parte por predisposição e na maioria dos casos por força das circunstâncias. Daí ter surgido em toda a Europa ocidental, no final do século XV e durante todo o século $\mathrm{XVI}$, uma legislação sanguinária contra a vagabundagem. Os ancestrais da atual classe trabalhadora foram imediatamente punidos pela transformação, que lhes foi imposta, em vagabundos e paupers. A legislação os tratava como criminosos "voluntários" e supunha que dependia de sua boa vontade seguir trabalhando nas antigas condições, que já não existiam (MARX, 1996, p.356).

As políticas de proteção social, apesar de não terem uma data especifica de surgimento, e não constituírem um fenômeno homogêneo, pode ser demarcada no período de desenvolvimento do capitalismo, através da intensificação da Revolução Industrial e os processos da intervenção estatal. Behring e Boschetti e (2011) afirmam que

Sua origem é comumente relacionada aos movimentos de massa social-democratas e ao estabelecimento dos Estados-nação na Europa ocidental do final do século XIX (Pierson, 1991), mas sua generalização situa-se na passagem do capitalismo concorrencial para o monopolista, em especial na sua fase tardia, após a Segunda Guerra Mundial (pós-1945) (p. 47).

Sem um caráter ainda estatal, as primeiras iniciativas que se assemelhavam a possíveis formas de "proteção" na passagem da fase pré-capitalista para a capitalista, tinham mais o aspecto de disciplinamento contra a ociosidade e a vagabundagem que propriamente segurança contra movimentos deletérios das novas formas de produção em ascensão. "Ao lado da caridade privada e de ações filantrópicas, algumas iniciativas pontuais com características assistenciais são identificadas como protoformas de políticas sociais" (idem, p.47).

Essas peculiaridades que perpassam a constituição das medidas de proteção social, têm semelhança com a experiência da Inglaterra pré-capitalista, a partir do aparecimento das máquinas e os efeitos perversos vividos pelos trabalhadores, que eram inseridos de forma precária em novas formas de produção, necessitando, desta forma, de leis que reduzissem esses efeitos.

Desta forma, podemos considerar que o caso da Inglaterra é emblemático para a análise do surgimento da classe trabalhadora fabril e das primeiras iniciativas para a constituição de legislações trabalhistas. 
Neste mesmo sentido, se entendemos o real como base primeira no processo de abstração dos conceitos e movimentos históricos, devemos compreender que "os países industrialmente mais desenvolvidos não fazem mais do que por, diante dos países menos desenvolvidos, o espelho do seu próprio devir" (MAZZEO, 2015, p.62). Ainda no que tange à Inglaterra, esta não se encaixa necessariamente como um "modelo de capitalismo [...] "mas como o momento em que as leis gerais encontraramse em sua plenitude, no sentido histórico do desenvolvimento das forças produtivas e das relações de produção" (id. lbid.).

Engels (2008) destaca que a revolução que se observou na Inglaterra "foi tanto mais grandiosa quanto mais silenciosamente se realizou. É por isso que a Inglaterra é também o país clássico para o desenvolvimento do principal resultado dessa revolução: o proletariado" (p. 45).

As mudanças nas relações sociais impostas por essas novas formas de produção, principalmente pela determinação de uma jornada de trabalho superior ao vivido até então, a inserção das máquinas e a desproteção, acompanhadas dos impactos engendrados por essas mudanças, transformaram a vida dos trabalhadores na Inglaterra; pois estes anteriormente "não precisavam matar-se de trabalhar; não faziam mais do que desejavam e, no entanto, ganhavam para cobrir suas necessidades e dispunham de tempo para um trabalho sadio" (idem. p. 46).

Com o desenvolvimento do maquinário industrial e a substituição processual da mão de obra humana e, portanto, a necessidade de se submeter a condições cada vez mais degradantes para sobreviver, chegou-se a constatar em setores produtivos da Inglaterra a sobreposição do trabalho mecânico sobre o trabalho manual, tendo como consequências,

por um lado, uma rápida redução dos preços de todas as mercadorias manufaturadas, o florescimento do comercio e da indústria, a conquista de quase todos os mercados estrangeiros não protegidos, 0 crescimento veloz dos capitais e da riqueza nacional; por outro lado, o crescimento ainda mais rápido do proletariado, a destruição de toda a propriedade e de toda segurança de trabalho para a classe operaria, a degradação moral, as agitações políticas (ENGELS, 2008, p. 50). 
Essa conjuntura é sem dúvida importante. A separação inicial dos trabalhadores dos meios de produção, ou seja, das suas condições independentes de realização do trabalho, dimensiona o processo de constituição da "acumulação primitiva"; e, para além disto, foi a partir das insatisfações do proletariado fabril com essas condições, que processualmente a luta por melhores condições de trabalho forçou a criação de algumas legislações, com vistas a protegê-los.

Em relação à acumulação primitiva, Marx (1985), define que esta "nada mais [é] que o processo histórico de separação entre produtor e meio de produção. Ele aparece como "primitivo" porque constitui a pré-história do capital e do modo de produção que lhe corresponde" (p. 262). Nessa definição, podemos verificar, ainda, que esta condição ultrapassava uma simples separação de trabalhadores e meios de produção, pretendia-se um perverso processo a fim de criar um mercado com trabalhadores "livres", mas, a partir de então, presos pela obrigatoriedade da venda de sua força de trabalho, em troca de um salário. Como evidencia Boschetti (2016), o sentido era "retirar dos trabalhadores o único meio de subsistência que dispunham a fim de obrigá-los a vender sua força de trabalho e participar "livremente" do processo de acumulação" (p. 80), sem qualquer tipo de proteção para os dilemas que surgiriam com a nova dinâmica.

Datando do século XIV, as Leis dos Pobres surgem a partir da verificação do Estado da inconsistência das ações da caridade cristã frente às desigualdades impostas pelas sociedades de classes que remontam os modos de produção escravista e feudal, antecessoras do modo de produção capitalista. Segundo PereiraPereira (2011),

em 1351, a Grã-Bretanha, sob o reinado de Eduardo III, se deparava não só com o extermínio de aproximadamente um terço de sua população pela Peste Negra, mas também com o desafio econômico de enfrentar uma crônica escassez de braços para trabalhar nas fazendas, implicando aumento de salários. Surge daí a estreita relação entre assistência social e trabalho, que vai constituir um imperativo categórico no capitalismo (p. 62).

Nesse contexto, essas leis serviam mais para inibir a vagabundagem e punir os pobres que se mudavam de paróquia buscando melhores ocupações, que propriamente protegê-los. O Statute of Labourers (Lei dos Trabalhadores) que tinha como intenção regular as relações de trabalho e a Poor Law Act (Lei dos Pobres), que 
limitou a mobilidade trabalhadores, podem ser caracterizadas como a "origem da assistência social institucional” (Idem, p.62).

Apesar da tentativa de contenção da "vagabundagem", a partir dessas leis, a preocupação com uma "convulsão" social era latente, assim como a busca por novas formulações legais. A referida autora afirma que "a partir do $43^{\circ}$ ano de reinado da rainha Elizabeth l", já se podia verificar, além da repressão, a subdivisão e distribuição dos grupos a serem atendidos em locais de correção particulares, a saber:

pobres impotentes para as Poor-houses (asilos); pobres capazes para o trabalho, ou mendigos fortes para as workhouses; e os capazes para o trabalho, mas, que recusavamse a fazê-lo (corruptos) para reformatórios e as crianças abandonadas, entregues a qualquer habitante que quisesse empregá-las (p. 64).

Com o aumento da população no último quarto do século XVIII, o processo de intensificação da industrialização e os efeitos dessa dinâmica na vida dos trabalhadores foram perversas: além dos desempregados, os empregados também demandavam intervenção do Estado. Sendo assim, essas leis já não eram efetivas e precisavam se adequar a essa nova dinâmica. O que se pode notar no processo de reforma dessas leis, é que havia a preocupação em conter as massas, por um lado, e, por outro, a ausência de teorias que questionassem contundentemente essas ações de Estado.

Nessa reforma, incorporou-se na nova lei, datada de 1834, o caráter liberal com o surgimento de fortes doutrinas antiprotecionistas. De acordo com Polanyi (2000),

primeiro, [surgiram] aquelas do período Speenhamland, 1795 a 1834. Segundo, as dificuldades causadas pela Poor Law Reform, na década que se seguiu a 1834. Terceiro, os efeitos deletérios de um mercado de trabalho competitivo após 1834 até que o reconhecimento dos sindicatos, nos anos 1870, passou a oferecer a necessária proteção (p. 104).

Essas leis exerceram efeitos desastrosos na vida das pessoas, ao funcionarem como mecanismos de punição ao invés de proteção; e a dominância de um livre mercado de trabalho representou o que de pior aconteceu para os trabalhadores. $\mathrm{O}$ 
período da Speenhanland, que tinha como propósito diminuir a inserção precoce do trabalhador comum no modelo de produção que surgia, baseado no manuseio do maquinário industrial, teve como resultado, a extrema pauperização e a desumanização no seu processo de inserção.

A Poor Law Reform, incentivou um mercado de trabalho competitivo e aboliu o "direito de viver", sendo caracterizada pela frieza e impiedade, atirando os pobres a sua própria sorte, retirando-lhe qualquer assistência e punindo-os com a obrigação de trabalhos extenuantes.

No terceiro período, o da constituição de um mercado de trabalho competitivo, representou o que havia de pior entre os períodos. O homem tinha sido abruptamente retirado das suas famílias e de suas raízes; se nas demais leis, havia a possibilidade real de perecimento "agora o período era a morte pela exposição" ao trabalho (POLANY, 2000, p.106).

Pereira-Pereira (2011), ao se referir a formação do conhecido Welfare State ${ }^{33}$ que se firmou em meados do século XIX, afirma que, isso só foi possível a partir de dois conjuntos de forças, a partir da segunda metade do século XVIII:

a) a Revolução Industrial, com a sua capacidade sem precedentes de produzir bens materiais e de poder livrar as classes laborais da pobreza herdada do processo de construção dos Estados nacionais, Europa Ocidental, desde o fim da Idade Media; e b) as mobilizações pela conquista de direitos individuais - civis e políticos - sob o efeito das revoluções burguesas (em particular francesa, de 1789) que transformaram a antiga ordem feudal na ordem capitalista dominada pela produção mercantil e pela ideologia liberal (p. 59).

Contudo, apesar dessa conjuntura "várias políticas sociais inglesas prestavam, em escala nacional, apoio público a cegos, surdos, mudos, insanos e indigentes incapacitados para o trabalho" (idem, p. 40); e a intervenção pública alemã, de modelo

33 "Podemos dizer que os Welfare States têm quase cem anos de idade enquanto que os movimentos de massa socialdemocratas, que estão na base de sua instituição, são um pouco mais antigos. Significativamente, os Welfare States tenderam a emergir nas sociedades em que o capitalismo e os Estados-nação estavam estabelecidos e, portanto, possuíam as condições básicas para o seu desenvolvimento (PIERSON, 1991, tradução nossa). 
bismarckiano ${ }^{34}$, demonstrou graus inovadores de legislação. Sobre essa afirmação, Pierson (1991) informa que,

o prelúdio da inovação legislativa nesse campo foi feito pelo chanceler Otto Von Bismarck, que criou compulsoriamente uma legislação de seguro social na Alemanha do século XIX. Além disso, Estados coloniais foram precoces em sua legislação de bem-estar. Isto em parte explica o precoce e rápido desenvolvimento do Welfare State na Austrália e em Nova Zelândia (PIERSON, 1991, tradução nossa).

Mas é necessário observar que apesar desse conjunto de legislações ter um sentido de inovação, o seu caráter conservador também era presente; pois, ao invés de constituírem instrumento de proteção contra o domínio do trabalho assalariado o prestigiava. Podemos verificar esta afirmativa na seguinte contribuição de PereiraPereira (2011),

Não se pode esquecer que a intervenção social de Bismarck tinha base conservadora e autoritária e, portanto, era avessa às ideias igualitárias da social-democracia então em circulação. E mais: era voltada exclusivamente para os trabalhadores ativos, fazendo com que a identificassem com um modelo profissional de proteção social, pois estavam fora do seu alcance os não inseridos no mercado de trabalho (p. 41).

Esse marco histórico é de muita importância para o nosso debate. Temos a consciência de que a história é construída e reconstruída nos marcos da materialidade humana, e com a constituição do "welfare state" não seria diferente. Pierson (2001), considera um dilema demarcar o inicio desse welfare state, tendo em vista que "a implantação de algumas medidas de regulação pública com vistas ao bem-estar, dificilmente constitui um critério suficiente [para defini-lo]" (PIERSON, 2001). Mas, ele aponta alguns movimentos que podem identificar um esboço característico desse marco, e que poderiam ser marcadores da constituição do welfare state:

\footnotetext{
34 "As primeiras iniciativas de benefícios previdenciários que vieram a constituir a seguridade social no século XX nasceram na Alemanha, no final do século XIX, mais precisamente em 1883, durante o Governo do Chanceler Otto Von Bismarck, em resposta às greves e pressões dos trabalhadores. (BOSCHETTI, 2009b, p. 2).
} 
a) introdução do seguro social - porque influenciou a mudança da concepção de que o pobre desempenha protagonismo na responsabilidade da sua condição, colocando no âmbito do Estado a necessidade do reconhecimento dessa vicissitude;

b) extensão da cidadania e desfocalização do welfare (bem-estar) público na pobreza extrema -abolindo a prevalência da punição à "vagabundagem" do pensamento estatal a priorização do livre funcionamento do mercado de trabalho e a política como alivio a pobreza.

c) o crescimento do gasto social -contrariando a concepção liberal do Estado, de ser mínimo para o social, e adotando medidas de financiamento das políticas sociais (PEREIRA-PEREIRA, 2011, p. 41-42).

Essa forma de proteção social restrita ao modelo bismarckiano de seguro social, só veio a ser alterada a partir da Segunda Guerra Mundial, com a publicação do Plano Beveridge em 1942 (PEREIRA-PEREIRA 2011; BOSCHETTI 2009b), na Inglaterra. De acordo com Beveridge (1987), esse plano tinha como proposito, "mejores niveles de trabajo, prosperidade económica y seguridade social" (p. 65).

el Plan de Seguridad de mi Informe es um plan para convertir las dos
ultimas palavras, "seguridad social" em hechos, para conseguir em la
Gran Bretaña que nadie dispuesto a trabajar mientras pueda, carezca
de ingresos suficientes para hacer frente em todas las épocas de su
vida a sus necessidades esenciales y las de su família. [... El plan de
Seguridad compreende três partes. Em primer lugar, um programa
completo de seguros sociales em prestaciones em dinero. Em
segundo lugar, um sistema general de subsídios infantiles, tanto
cuando el padre gana dinero como cuando no lo gana. Finalmente, um
plan general de cuidados médicos de todas clases para todo el mundo
(BEVERIDGE, 1987, p. 65).

Desta forma, seria um Plano de caráter universal e que independeria da condição de trabalho. Apesar dele influenciar diversos países no mundo, ainda na contemporaneidade, houve modificações, adequações e deturpações da sua concepção principal - a universalidade. Em relação a essas disputas de concepção, Boschetti (2009b), afirma que, 
as diferenças desses princípios provocaram o surgimento e instituição de diferentes modelos de seguridade social nos países capitalistas, com variações determinadas pelas diferentes relações estabelecidas entre o Estado e as classes sociais em cada país. Hoje, é difícil encontrar um "modelo puro". As políticas existentes e que constituem os sistemas de seguridade social em diversos países apresentam as características dos dois modelos [bismarckiano e beveridgiano] com maior ou menor intensidade (p. 2).

Como observamos, a história da constituição da classe trabalhadora e suas mobilizações por melhores condições de trabalho e de vida, se imbricam com o desenvolvimento dos direitos políticos, civis e sociais. E, mesmo que os direitos políticos tenham sido construídos de forma lenta e à força, eles contribuíram "significativamente para ampliar os direitos sociais, e para tensionar, questionar e mudar o papel do Estado no âmbito do capitalismo a partir do final o século XIX e início do século XX" (BEHRING e BOSCHETTI, 2011, p. 64).

A verificação histórica dessas leis evidencia o dilema que a proteção social enfrenta desde a sua formação. Como já informado, apesar da mudança na dinâmica do Estado hoje, os reflexos da intensificação do modo de produção capitalista produzem um percurso com rupturas entre aspectos passados, mas, também a permanência e aprofundamento de novos dilemas. Por exemplo, as estratégias contemporâneas que vêm sendo adotadas na proteção social, têm forte ligação com a busca por sistema protetivo que conjugue mínima oferta de distribuição monetária e obrigatória ativação para o trabalho.

Nesse movimento, busca-se a conciliação do conflito de "como assegurar níveis de benefícios suficientemente elevados para a manutenção de um padrão de vida tolerável, mas que não sejam tão altos que possam desencorajar os pobres a procurar trabalho"? (HIGGINS, 1983, p.100). (Tradução nossa ${ }^{35}$ ).

\subsection{Assistência social e a lógica do retorno ao Trabalho.}

As estratégias de proteção social que se baseiam em concepções mercadológicas e liberais como, por exemplo, o processo de ativação dos

35 Texto original: how to ensure that the levels of benefit are sufficiently high to maintenance of a tolerable standard of living but not too high to discourage the poor from seeking work? 
demandantes das políticas sociais para o mercado de trabalho, fazem parte de uma abordagem de intervenção que tem na ética capitalista do trabalho o parâmetro de satisfação de necessidades, baseado no mérito; e seu fim principal é a "autonomização" dos indivíduos com o passar do tempo de permanência na proteção social, ou seja, a lógica do retorno para o trabalho da forma mais rápida possível. Segundo Boschetti (2012),

tal perspectiva reforça a primazia do trabalho a qualquer custo, introduz a exigência de uma relação mais direta entre assistência e trabalho e fortalece a velha dicotomia trabalho-assistência, segundo a qual os "pobres aptos ao trabalho" devem se submeter a qualquer tipo de atividade para ter o direito de receber um benefício assistencial. Com poucas diferenças em termos de estratégias de implementação, essas políticas de ativação estão na base das principais "reformas" dos anos 2000 (p.784).

A busca pela legitimidade desse modelo de proteção, além de encontrar suporte na sociedade, que adota a ética capitalista do trabalho, é amparada na construção teórica liberal que confunde liberdade com livre concorrência, reificando a oposição entre o direito e o mérito, como podemos verificar em Hayek (2010), ao afirmar que,

não há dúvida de que a segurança adequada contra as privações, bem como a redução das causas evitáveis do fracasso e do descontentamento que ele acarreta, deverão constituir objetivos importantes da política de governo. Mas, para que essas tentativas sejam bem-sucedidas e não destruam a liberdade individual, a segurança deve ser proporcionada paralelamente ao mercado, deixando que a concorrência funcione sem obstáculos ( $p$ 137).

Em relação a essas estratégias de ativação em um panorama global, o dinamarquês Peter Abrahamson (2009), denuncia o retorno dessas medidas na política de bem-estar, mesmo onde este era mais progressista. Tal é o caso da Dinamarca, a reforma da proteção social daquele país, desde 1994. Segundo este autor, na Dinamarca a nova Lei da Assistência Social ${ }^{36}$, de 1997 , fortaleceu as

\footnotetext{
36 "A elegibilidade para Assistência Social, seja sob a forma de serviços ou transferências, está - por definição - sujeita a meios, necessidades e teste de trabalho; ela é discricionária, isto é, focalizada. Os beneficiários têm obrigatoriedade de passar por atividades como educação, treinamento, e de aceitar o trabalho que lhes é oferecido" (ABRAHANSON, 2009, p.248).
} 
medidas de workfare, tendo em vista a obrigatoriedade dos demandantes de participarem das atividades laborais. Assim,

no caso de o beneficiário da assistência rejeitar uma oferta de trabalho ou ativação sem justificativa e não estiver disponível para trabalhar, as autoridades locais podem interromper o pagamento da assistência. No caso do beneficiário da assistência em espécie rejeitar uma oferta de ativação ou não conseguir apresentar um curso razoável quando for oferecida a ativação, as autoridades locais podem reduzir a assistência para até um terço (p. 249).

Nessa relação entre Assistência Social e Trabalho, cria-se condições para o fácil "desligamento" da proteção social, empurrando os demandantes para o qualquer trabalho, desnudando, dessa forma, uma face perversa da política social, que é, frequentemente percebida como punição pelo trabalhador desempregado; e que tem sido aceita não apenas por ser obrigatória, mas porque a pessoa que o rejeita correrá o risco de perder a cobertura da assistência social (idem).

A condição da aceitação de qualquer trabalho torna-se requisito ou condição obrigatória para os que demandam a permanência na proteção social; desta forma, a assistência social estrutura-se como um complemento de renda temporário à "incapacidade de autossustento". E tenta construir na sociedade a "sensação" de que - Estado não está apenas repassando renda para os demandantes, mas, "incentivando" a sua volta para o mercado de trabalho.

Desenhando outro panorama dos programas de ativação para o trabalho e de transferência de renda, na Europa, Boschetti (2012) informa que "as contrarreformas no âmbito dos sistemas de proteção social atingiram todos os países na década de 1990-2000 e alteraram profundamente sua lógica redistributiva" (p. 778).

Na França, a inserção nos programas de transferência de renda tornara-se precondição para a aceitação e permanência no mercado de trabalho precário, mantendo os repasses temporariamente para os trabalhadores recém ingressos nesse mercado. Essa conjuntura - da redução da proteção social como direito e da sua potencialidade de questionamento dos efeitos deletérios do trabalho assalariado - confere a este trabalho a única possibilidade de proteção passível de aceitação, tendo na América Latina ampla adesão. Com efeito, 
a redução de direitos trabalhistas é uma resposta da ofensiva burguesa à crise do capital em sua busca incessante por superlucros. Cresce e ganha força, mesmo entre a classe trabalhadora, a retórica da aceitação de qualquer negociação para manter o emprego, mesmo que isso signifique perder direitos. As políticas de ativação de trabalho seguem esta lógica: incitar o trabalhador a aceitar qualquer tipo de trabalho (BOSCHETTI, 2015, p. 4).

No Brasil, apesar da sua adesão inicial ao modelo de intervenção baseado no seguro social, a partir da Constituição de 1988 a seguridade social apontava para a universalização. Contudo, com a adoção do projeto de desenvolvimento econômico à custa do desincentivo estatal no campo da garantia dos direitos sociais, com fortes influências da ideologia neoliberal, a universalização dos direitos sociais foi muito sabotada.

Segundo Silva e Silva et al (2008), os anos de 1990, têm como centralidade a contradição no âmbito das políticas de bem-estar no Brasil, pois, apesar de haver um grande avanço no processo de institucionalização da Seguridade Social, houve também um movimento restritivo na sua implementação, com o Estado privilegiando critérios cada vez mais focalizados, haja vista os requisitos de acesso aos programas de transferência de renda (p. 30).

As medidas de ativação para o mercado de trabalho no Brasil, a partir da assistência social, podem ser notadas nas suas normativas, sendo iniciada pela inclusão dessa diretriz na Lei Orgânica da Assistência Social - LOAS (1993) e demais normas subseqüentes as quais prevêem, no âmbito da Assistência Social, programas de transferência de renda com contrapartidas, entre as quais a inserção produtiva, como é o caso do Programa Bolsa Família - PBF, e cursos de qualificação para o trabalho, que são ofertados nos Centros de Referência da Assistência Social - CRAS.

Recentemente na Comissão de Trabalho, de Administração e Serviço Público da Câmara dos Deputados, houve a aprovação da proposta ${ }^{37}$ que obriga o vínculo de

\footnotetext{
37 Ver os projetos de lei: (PL-6021/2009 - que condiciona a concessão de Bolsa Família à inscrição em programa de qualificação profissional complementar); (PL-5863/2013 - que cria o Programa Nacional de Inclusão no Mercado de Trabalho, para mulheres beneficiadas pelo Programa Bolsa Família); (PL-6941/2013 - dispõe sobre período adicional para o recebimento dos benefícios do Programa Bolsa Família quando houver adesão ao Programa Microempreendedor Individual (MEI)); (PL-7297/2014 - Dispõe sobre a contratação de beneficiários do Programa Bolsa Família e dá outras providências.); ( $\mathrm{PL}-1315 / 2015$ - conceder incentivo fiscal a empresas que contratarem beneficiários do Programa Bolsa Família.); (PL-1369/2015 - Altera a Lei no 10.836, de 9 de janeiro de 2004, que cria o Programa Bolsa Família, para instituir a implantação de Centros de Capacitação Profissional);
} 
familiares em programa de qualificação profissional, para a concessão do Bolsa Família. Esse projeto

estabelece que o beneficiário do Bolsa Família deverá comprovar, no prazo de 90 dias, a inscrição e a participação em curso de educação profissional ou tecnológica. Após o curso de qualificação, o currículo do profissional será incluído em cadastro de vagas das agências do trabalhador. O beneficiário que recusar mais de quatro propostas de trabalho ou começar a atuar como profissional liberal terá o benefício suspenso (BRASIL/CD, 2016, grifos nossos).

Segundo o referido projeto, por meio do condicionamento da transferência de renda com a obrigatoriedade de um curso de qualificação, os efeitos benéficos dessa política seriam ampliados e aprofundados. Na Lei nํㅜ 10.836, de 9 de janeiro de 2004, que cria o Programa Bolsa Família, o seu artigo 3ํ, condiciona o acesso aos benefícios às seguintes condicionalidades:

exame pré-natal, ao acompanhamento nutricional, ao acompanhamento de saúde, à freqüência escolar de $85 \%$ (oitenta e cinco por cento) em estabelecimento de ensino regular, sem prejuízo de outras previstas em regulamento (BRASIL, 2004).

A partir do Projeto de Lei nº 6.021, DE 2009, foram incluídas nas condicionalidades dos beneficiários, as obrigações "relativas à educação profissional e ao emprego de membro da família" (p.7); e no $\S 1^{\circ}$, do inciso $\mathrm{V}$, há preceituação de que "os benefícios serão suspensos após a quarta proposta de emprego encaminhada e não atendida, ou se decorridos 30 dias do início da atividade laboral remunerada".

Diante do exposto, verificamos, além da focalização do programa, a tentativa do condicionamento do acesso a obrigações e a ativação para o trabalho, com o discurso de aprofundamento dos efeitos do programa, escamoteando o seu real desígnio que é: subsumir o direito (que já é equivocado pelos critérios estabelecidos) à compulsiva ativação para o trabalho.

(PL-2105/2015 - Altera o art. $3^{\circ}$ da Lei oㅜ 10.836, de 9 de janeiro de 2004, que cria o Programa Bolsa Família, para dispor sobre as condicionalidades relativas à educação profissional e ao emprego; (PL-3084/2015 - Dispõe sobre a condicionalidade de participação em curso de educação profissional ou tecnológica no Programa Bolsa-Família). 


\section{3 - INSTITUCIONALIZAÇÃO DA ASSISTENCIA SOCIAL PÓS 1988 E A SUTIL OBRIGATORIEDADE DO TRABALHO.}

Como já referido, de forma introdutória em capitulo anterior, o processo de préinstitucionalização da política de Assistência Social, no Brasil, não se deu de forma homogênea, sem conflitos ou mesmo sem equívocos; antes foi um processo marcado por disputas que ora afirmavam e ora renegavam as estruturas tradicionais, clientelistas, de se fazer assistência no país.

Nessa conjuntura, eram, no fundo, as contradições do modo de produção capitalista que impunham resistências à afirmação da assistência como política pública concretizadora de direitos sociais; ou seja, tais contradições tinham por base os velhos conflitos "expressos no confronto entre as logicas da rentabilidade econômica e das necessidades sociais" (PEREIRA-PEREIRA, 2002, p. 63).

Nesse confronto, do qual a assistência social antes da sua inserção na Constituição de 1988 não constituía ameaça, prevaleciam: praticas pontuais de "higienização social" e assistencialismo; e mais, recorrentes confusões de responsabilidades e finalidades entre "instituições públicas e privadas sem nenhuma regulamentação, [que] faziam da assistência uma ajuda provisória às 'incapacidades' individuais e um instrumento clientelista dos poderes públicos" (BOSCHETTI, 2002, p.14). Sendo assim, a assistência tornava-se mera prática, inserida em instituições de cunho punitivo e de benemerência, sendo usada de forma espontaneista, padecendo da ausência de um arcabouço normativo que delimitasse suas obrigações, limites e possibilidades. Segundo Pereira-Pereira (2002), essas práticas, eram

\footnotetext{
caracterizadas mais como a doença da assistência - o assistencialismo - ou desassistência, como prefiro chamar, que sempre constituíram a contra-face da cidadania, porque não tinham compromissos éticos e cívicos e, por isso, impediam que os "assistidos" tivessem o direito de ter direitos à satisfação condigna de suas necessidades (p.64).
}

Ademais, essas práticas assistencialiastas tinham como antítese o trabalho, tornando-se este um critério de exclusão ao acesso ao trabalhador; ou seja, só era reconhecido como "merecedor" o indivíduo que não trabalhasse, por conta de restrita incapacidade para esta atividade. Desta forma, "é possível afirmar que a assistência 
social sempre se debateu para encontrar seu lugar e sua identidade ao lado da organização social do trabalho" (BOSCHETTI, 2008, p.5).

Como o trabalho desempenha protagonismo no acesso, ou não, a práticas assistenciais, e as condições dos trabalhadores tendiam a se precarizar de forma crescente dada à busca incessante do capital por reprodução ampliada, essa assistência, segundo Sposatti et al (1998), começou a ser assumida pela esfera estatal sob duas óticas: "uma que se insinua como privilegiada para enfrentar politicamente a questão social; outra para dar conta de condições agudizadas de pauperização da força de trabalho" (SPOSATTI et. al., 1998 p. 41). Isso, além das próprias práticas que já eram recorrentes em forma de benemerência estatal, institucionalizavam-se, assim, o aparato de solidariedade presentes na sociedade (idem, p. 41).

Somou-se a este processo, a intervenção estatal por meio de uma "proteção" corporativista e meritocrática, tendo em vista a exclusividade da proteção a algumas categorias de trabalhadores formais, confirmando, então, a adoção do modelo de seguro social do tipo bismarckiano. Boschetti (2003) em relação a esse modelo europeu de proteção, denominado de seguro social, acrescenta que, o modelo bismarckiano é identificado como sistema de seguros
sociais, pois suas características assemelham-se às de seguros
privados: Em relação aos direitos, os benefícios cobrem
principalmente (e às vezes exclusivamente) os trabalhadores, o
acesso é condicionado a uma contribuição direta anterior e o montante
das prestações é proporcional à contribuição efetuada; Quanto ao
financiamento, os recursos são provenientes, fundamentalmente, da
contribuição direta de empregados e empregadores, baseada na folha
de salários; Quanto à gestão, teoricamente (e originalmente), deveria
ser gerido pelos contribuintes, ou seja, empregadores e empregados
(p. 62).

Sendo assim, podemos afirmar que até a década de 1930 havia ampla isenção do Estado em relação ao processo de intervenção na sociedade, e os casos em que se constatava a ausência da condição individual de reprodução da vida, era tratado como um "desvio moral" de "vagabundagem", portanto caso de polícia. Desta forma, a assistência Social baseava-se por critérios de não cidadania.

Em meio a essa relação entre assistência e trabalho e, principalmente, a partir das primeiras legislações que visavam regular as condições para o processo de 
produção no Brasil, vigorava, por um lado, o modelo previdenciário ${ }^{38}$, tendo em vista a necessidade da contribuição dos trabalhadores; e, de outro lado, o modelo assistencialista, sem necessidade de contribuição, e a institucionalização ${ }^{39}$ das práticas "assistenciais" para os "vulneráveis" e "incapazes".

Segundo Behring e Boschetti (2011), "esse período de introdução da política social brasileira teve seu desfecho com a Constituição de 1937" (p. 108), observando que essa Constituição reafirmava a urgência do reconhecimento das categorias trabalhistas, e também com a inauguração da Consolidação das Leis do Trabalho CLT, que foi instituída no governo Vargas, em 1ํ de maio de 1943 (p. 108).

É importante mencionar que apesar do processo de industrialização e da promulgação dessas legislações reguladoras do trabalho terem auferido maior grau de reconhecimento das profissões - e possibilitado o acesso a alguns direitos decorrentes das atividades laborativas - o Brasil, nesse contexto, apesar das "transformações vividas no que concerne à reestruturação salarial, [estas] não se transformaram em uma condição salarial generalizada a toda (ou quase toda) a população economicamente ativa" (BOSCHETTI, 2008, p. 81). Desta forma, se perpetuaram as disparidades sociais ${ }^{40}$, produzindo um contexto no qual se, para as profissões já amplamente reconhecidas as condições de trabalho/assalariamento eram difíceis, para os trabalhadores recém reconhecidos e/ou ainda liberais tornavase impossível.

Neste cenário combinaram-se as especificidades da formação do mercado de trabalho no Brasil; a cultura política tradicionalista e de subserviência e o modelo de proteção social restrito, vinculado ao trabalho e por via da contribuição.

38 "[...] foi implementada com base no princípio da solidariedade profissional e na lógica da cobertura dos riscos derivados da perda da renda do trabalho (nos casos de invalidez, velhice, doença e morte). Tal política era financiada por um sistema de repartição, a partir principalmente da contribuição dos trabalhadores e empregadores, e organizava-se em um sistema nacional público (INPS e, a partir de 1990, INSS)" (BOSCHETTI, 2008, p.6).

${ }^{39}$ A criação da Legião Brasileira de Assistência social -LBA, é um exemplo. Segundo Sposati (1998), "organismo este que assegura estatutariamente sua presidência às primeiras damas da Republica. Representa a simbiose entre a iniciativa privada e a publica, a presença da classe dominante enquanto poder civil e a relação benefício / caridade x beneficiário / pedinte, conformando a relação básica entre Estado e classes subalternas (p. 45-46).

40 Como afirma Yazbeck (1995) "Desnecessário é lembrar o aumento do número absoluto de pobres nos últimos anos e a conjuntura econômica dramática, dominada pela distância entre minorias abastadas e massas miseráveis, que evidencia o longo caminho que nos separa de uma necessária redistribuição de renda e da constituição de políticas que se voltem às demandas dos grandes contingentes esmagados pela pobreza" (p. 8). 
Em vista disso, o percurso de desenvolvimento da assistência antes da sua inserção na Seguridade Social, sempre esteve explicitamente vinculado a condicionantes impositivos do mundo do trabalho. Somava-se a essa conjuntura "o postulado liberal do mérito e da dignidade ligados ao trabalho" que, segundo Boschetti (2008), legitimava "a máxima segundo a qual a assistência social estimulava o ócio e o desperdício, a aceitação da miséria como um fenômeno natural e a ideia de que a assistência social devia ser um simples paliativo" (p. 8).

Os anos 1980 e a luta pela democracia ${ }^{41}$, ou pela democratização, ${ }^{42}$ no Brasil, despontam como uma possibilidade de virada nas práticas assistencialistas e na concepção da assistência social como um não direito de cidadania. Em relação à democratização na sociedade brasileira, Bravo (2008), afirma que nesse processo, datado historicamente a partir de 1980, que superou o "regime ditatorial instaurado em 1964, [a sociedade brasileira] experimentou uma profunda e prolongada crise econômica que persiste até os dias atuais" (p. 44). E continua:

Um aspecto importante a ser ressaltado, nesse período, foi o processo constituinte e a promulgação da Constituição Federal de 1988, que representou no plano jurídico, a promessa de afirmação e extensão dos direitos sociais em nosso país frente à grave crise e às demandas de enfrentamento dos enormes índices de desigualdade social (idem, p. 44).

Em relação às mudanças no âmbito do Estado brasileiro e à crise, capitalista então em curso, Behring e Boschetti (2011), contribuem afirmando que as movimentações para uma "reconfiguração do papel do Estado capitalista nos anos

41 "A noção de democracia é concebida por diversos autores como um processo histórico e está relacionada à soberania popular. Nessa concepção, a democracia representativa é considerada uma vitória dos movimentos organizados da sociedade civil; entretanto, é percebida como uma vitória parcial, uma vez que na sociedade capitalista existe a hegemonia da classe capitalista dominante, havendo um limite interno, pois as principais decisões econômicas são tomadas pelo poder privado" (BRAVO, 2008, p. 45).

42 "As múltiplas objetivações que formam a democracia moderna surgem como respostas, dadas em determinado nível concreto do processo de socialização do trabalho, ao desenvolvimento correspondente dos carecimentos de socialização da participação política. Embora formem um conjunto sistemático, essas objetivações vão se desenvolvendo ao longo do tempo, razão pela qual Lucáks, ao falar de democracia, prefere corretamente usar o termo "democratização [...]" (COUTINHO, 2000, p.23). Ou como afirma Lucaks (1987), "Per questo viene qui intrapeso il tentativo di considerare la democrazia (meglio: la democratizzazione, giacché, anche qui ontologicamente, si tratta in primo luogo di un processo e non di uno stato) [...]" (p. 25) (destaque nosso). 
1980 e 1990, e seus impactos para a política social, estão articuladas a uma reação burguesa à crise do capital que se inicia nos anos 1970" (p. 112).

Em defesa da democratização do país e da efetivação da Constituição de 1988, alguns movimentos já eram esboçados tentando redefinir e situar a assistência social na nova conjuntura. É o que verificamos na contribuição de Boschetti (2008), ao afirmar que,

desde a metade dos anos 1980, esboçou-se uma forma inovadora de regulação social baseada em um sistema de proteção que estabelecia uma associação cada vez mais estreita e complexa entre assistência social, previdência e exercício do trabalho. Tratava-se de uma tentativa de, ao mesmo tempo, aclarar noções e reorganizar ações sociais marcadas historicamente pela opacidade e indefinição conceitual (p. 8).

Em 1988, com as lutas sociais pela democracia e a promulgação da Constituição Federal de 1988, a assistência social é inserida na Seguridade Social, junto com as políticas de Saúde e Previdência Social. A "carta cidadã" que surge como um divisor histórico no Brasil, por elencar um conjunto reconhecido de direitos, define logo de início, no seu texto, que um dos princípios fundamentais do Estado Brasileiro são "os valores sociais do trabalho e da livre iniciativa" (BRASIL, 1988), evidenciando o privilegiamento do trabalho.

Da mesma forma, na seção destinada à definição dos direitos sociais, o trabalho também é preceituado, no artigo 6ำ como direito, deixando a interpretação livre, seja para o trabalho protegido, seja para o desprotegido e/ou degradante, pois seria um equívoco afirmar que no contexto brasileiro, de raízes trabalhistas escravocratas, só existe um tipo de trabalho, apesar do espraiamento no sensocomum de que qualquer trabalho é dignificante.

No campo das políticas da Seguridade Social, ao contrário da Saúde, que é universal e a Previdência Social, que é contributiva, a Assistência Social "será prestada a quem dela necessitar" (BRASIL, 1988), tendo como objetivos:

I - a proteção à família, à maternidade, à infância, à adolescência e à velhice;

II - o amparo às crianças e adolescentes carentes; 
III - a promoção da integração ao mercado de trabalho;

IV - a habilitação e reabilitação das pessoas portadoras de deficiência e a promoção de sua integração à vida comunitária;

V - a garantia de um salário mínimo de benefício mensal à pessoa portadora de deficiência e ao idoso que comprovem não possuir meios de prover à própria manutenção ou de tê-la provida por sua família, conforme dispuser a lei (BRASIL, 1988, grifos nossos).

Em reforço ao que já foi mencionado sobre privilegiamento do trabalho no texto constitucional, observa-se, no artigo 203 da Constituição Federal de 1988, que um dos objetivos da Assistência Social é a "promoção da integração ao mercado de trabalho"; ou seja, neste caso, contraditoriamente, a assistência social ultrapassa a sua condição de antítese do trabalho, em conformidade com a sua concepção tradicional - que exige comprovação de incapacidade laboral de seus beneficiários para sintonizar-se com a obrigação de ativar os demandantes de sua proteção para o mercado de trabalho. Em relação a esse fato, Boschetti (2016), assim se expressa:

o reconhecimento da assistência social como direito no âmbito do Estado Social capitalista não foi capaz de superar a inerente tensão entre assistência social e trabalho - embora possa tê-la diluído em alguns contextos e condições especificas - porque se trata de uma tensão insolúvel na sociedade capitalista determinada pela exploração do trabalho como condição para a extração de mais-valia (BOSCHETTI, 2016, p. 76).

A preceituação constitucional desse objetivo, ou condição, de ser a assistência social uma política em articulação direta com o mercado de trabalho, pode representar uma concessão à ética capitalista do trabalho, desde então em ascensão, que defende a autossustenção de todos os indivíduos. Em outras palavras é a ética capitalista do trabalho inserida no sistema de Seguridade Social ${ }^{43}$, que, além de privilegiar na previdência social o seu eixo contributivo, busca caminhos para

43 "O acesso à seguridade social pela via do trabalho pôde garantir uma proteção mais universalizada nos países que garantiram uma situação de quase pleno emprego entre as décadas de 1940 e 1970. Sabe-se que nem os países nórdicos e nem os países da Europa Central garantiram o pleno emprego para todos os seus trabalhadores, de modo que esse padrão de seguridade social, fundado na lógica do seguro, só universaliza direitos se universalizar, igualmente, o direito ao trabalho, já que os benefícios são condicionados ao acesso a um trabalho estável que permita contribuir para a seguridade social" (BOSCHETTI, 2008, p. 4). 
"autonomizar", os demandantes da Assistência Social de sua proteção, pela via do trabalho. Isso, sem falar da recusa do movimento privatista, no campo da saúde, do caráter universal e gratuito desta política.

Todas essas resistências ao perfil democrático da Constituição Federal de 1988, não teriam tido força se não contassem com um contexto histórico favorável. Isto é, se a "logica previdenciária-assistencial"44 concebida pelos movimentos democráticos não conflitasse "com o tipo e o estágio do sistema econômico e social predominante" (BOSCHETTI, 2008, p.10).

Entretanto, apesar desses óbices enfrentados pela assistência social, após a sua inserção da Seguridade social, as suas possibilidades como política pública também se ampliaram, mesmo pelo longo caminho para a sua materialização, na perspectiva dos direitos, em uma realidade carente de tradição democrática. Em vista disso, concordamos com o entendimento de Pereira-Pereira (2002) de que

foi, pois, no âmbito das leis, dos conceitos e das ideias, definidos a
partir da crise do regime autoritário, que a assistência social brasileira
lavrou tentos não desprezíveis; ganhou um paradigma norteador, isto
é, pressupostos ou fundamentos teóricos, éticos e cívicos, que,
informados pelos fatos, presidem a atividade política; resifnificou-se,
do ponto de vista conceitual assumindo nova identidade; introduziu-se
nos ordenamentos jurídicos superiores, nos currículos das
Universidades, nos círculos intelectuais e políticos formadores de
opinião, nos debates parlamentares e nas pautas das ações e
propostas orçamentárias dos governos. Transformou-se também em
instigante objeto de estudos e pesquisas; em matéria suscitadora de
polêmica; em bandeira de luta de grupos simpatizantes (e, até,
militantes); e em espinha atravessada na garganta de setores
conservadores (alguns deles raivosos), que não admitem reconhecê-
la como direito do cidadão e dever do Estado. Enfim, contrariando
todas as previsões e preconceitos arraigados culturalmente
(PEREIRA, 2002, p. 65).

Dentre os desafios a enfrentar, pela assistência social, estava a necessidade de consolidar sua organização e distribuir as responsabilidades, assim como implementar, distribuir e delimitar as suas fontes de financiamento. Somam-se a essa

\footnotetext{
44 "No Brasil, a tentativa de estabelecimento, com a Constituição de 1988, de um sistema baseado no complexo previdenciário-assistencial, ou seja, sobre a primazia do trabalho, fez emergir o que consideramos o grande paradoxo do Estado social brasileiro: a organização da seguridade social sob a lógica do complexo previdenciário-assistencial em uma sociedade não-salarial, ou com frágil assalariamento" (BOSCHETTI, 2008, p. 10).
} 
conjuntura, as eleições para presidente da República, no fim de 1989, rompendo com 21 anos de governo ditatorial.

Com a eleição de Fernando Collor, iniciaram-se as disputas para a aprovação das leis que regulamentariam as políticas de Seguridade Social, sendo que, em 1990, o Projeto da LOAS foi vetado pelo então presidente. A transformação em lei, desse projeto, já previamente aprovado no Congresso Nacional, só foi possível cinco anos depois da promulgação da Constituição Federal, em 7 de dezembro de 1993, já sob o governo de Itamar Franco, que substituiu Fernando Collor, afastado por um processo de impeachment. A aprovação da Lei № 8.742, de 7 de dezembro de 1993, só foi possível a partir de uma série de mobilizações de protagonistas e estudiosos da área ${ }^{45}$.

A partir da da LOAS, segundo Pereira (2002), a política de Assistência Social passou a ser concebida como: a) uma política pública, integrada às demais políticas sócio-economicas congêneres; b) política de natureza incondicional, gratuita e desmercadorizável; c) política sob competência primaz do Estado, com aval e controle da sociedade (p. 65).

Contudo, mesmo com esses avanços, a LOAS reafirmou a relação de sintonia e tensão entre a assistência social e o trabalho, ainda que a política em questão se mantivesse não-contributiva, isto é, que não dependesse de contribuição monetária dos beneficiários. Assim, seja por meio da promoção da inserção dos beneficiários no mercado de trabalho, prevista nos seus objetivos, seja pelo condicionamento da ausência de renda para se fazer jus aos benefícios, - a exemplo do Benefício de Prestação Continuada - BPC, observam-se requisitos que "reforçam a histórica clivagem entre aptos e inaptos ao trabalho" (BOSCHETTI, 2003, p. 80).

É interessante ainda observar, segundo Boschetti (2003), que mesmo com a reafirmação desses dilemas enfrentados pela assistência social na sua relação com o trabalho, e incorporados pela LOAS, essa lei configura um mecanismo de oposição a essa lógica. Exemplo: assegurando o acesso dos usuários aos direitos

\footnotetext{
${ }^{45}$ É mais que necessário evidenciar o nome de algumas protagonistas na luta pela aprovação da LOAS. Entre elas estão Potyara Pereira, Laura Lemos Duarte, Carmelita Yazbeck, Aldaiza Sposati, Rosangela Batistoni e Ana Ligia Gomes. Bem como as entidades de representação da categoria dos Assistentes Sociais: CFESS, ABEPESS, CRESS, que eram CEFAS e CRAS (SPOSATI, 2007, p.58).
} 
socioassistenciais, que se materializam por meio de serviços, programas e projetos ${ }^{46}$; e estes, por serem caracterizados por um amplo e articulado conjunto de ações no âmbito da Assistencia Social, poderão assumir um sentido de política preventiva, rompendo com as lógicas contratual e restritiva características das prestações monetárias (idem, p. 81). Todavia, esse fato que não confirmou ou perdurou, tendo em vista o protagonismo atual dos programas focalizados e dos recorrentes cursos de qualificação para o trabalho.

Porém, como o Brasil é recorrentemente lembrado pelas suas marcas conservadoras, tanto pela via da omissão quanto por recaídas restritivas, não seria diferente com a Assistência Social. De acordo com Couto, Yazbeck e Raichelis (2012),

da Carta Constitucional à aprovação da LOAS passaram-se cinco anos; para o pagamento do único benefício previsto na lei (e já na Constituição em seu artigo 203), para idosos e portadores de deficiência, passaram-se mais dois anos e com severas restrições do ponto de vista do vínculo do benefício (um salário mínimo mensal) a um baixíssimo corte de renda per capita dos beneficiários (p. 56).

Como já mencionado, a conjuntura em que se constrói a resignificação da assistência social como política pública devida pelo Estado, sob o controle direto e indireto da sociedade, entra em atrito com o ideário neoliberal que invade o Brasil, na virada de $1990^{47}$, fruto de exigências externas, principalmente dos organismos

${ }^{46}$ A) Consideram-se como serviços assistenciais - "as atividades continuadas que visem à melhoria de vida da população e cujas ações estejam voltadas para as necessidades básicas da população [...]"; b) entende-se por programas - "ações integradas e complementares com objetivos, tempo e área de abrangência definidos para qualificar, incentivar e melhorar os benefícios e os serviços assistenciais [...]"; c) entende-se por projetos de enfrentamento à pobreza - investimentos econômicos-sociais nos grupos populacionais em situação de pobreza, buscando subsidiar técnica e financeiramente iniciativas que lhes garantam meios e capacidade produtiva e de gestão para a melhoria das condições gerais de subsistência, elevação do padrão de qualidade de vida, preservação do meio ambiente e organização social” (BOSCHETTI, 2003, p. 82).

47 '[...] as redefinições mais recentes do' capitalismo contemporâneo, as mudanças nas relações entre capital e trabalho, o processo de globalização, as transformações que se operam no Welfare State, e o avanço do neoliberalismo enquanto paradigma político e econômico, trazem para o campo da Seguridade Social no país, profundos paradoxos. Pois, se de um lado o Estado brasileiro aponta constitucionalmente para o reconhecimento de direitos, por outro se insere no contexto de ajustamento a essa nova ordem capitalista internacional, onde se observa a desmontagem de conquistas no campo social e onde as políticas ortodoxas de estabilização da economia, com suas restrições aos gastos públicos, reduzem e direcionam os investimentos sociais do Estado" (YAZBECK, 1995, p. 10). 
multilaterais que entendiam a "necessidade" da retração estatal, e uma "profunda incompatibilidade entre ajustes estruturais da economia e investimentos sociais do Estado" (COUTO, YAZBECK e RAICHELIS, 2012, p. 56).

Ainda nesse processo de institucionalização, a assistência social só vai ter aprovada a sua primeira Política Nacional (PNAS), em 1995, numa conjuntura em que se afirmava o seu perfil neoliberal e focalizado na pobreza por meio de ações de solidariedade civil.

O período de governo do presidente Fernando Henrique Cardoso (1995 2001), marcou a assistência social pelo desrespeito governamental ao processo de lutas e conquistas (tendo como marco a LOAS), que buscavam legitimá-la como um direito social. Nesse governo, que durou oito anos, o "grande projeto" de intervenção social se deu por meio do projeto "Comunidade Solidaria" que "caracterizou-se por grande apelo simbólico, com ênfase em ações pontuais, focalizadas em 'bolsões de pobreza', direcionadas apenas aos indigentes, aos mais pobres entre os pobres" (COUTO, YAZBECK e RAICHELIS, 2012, p. 58).

Podemos dizer que foi a partir da IV Conferência Nacional de Assistência Social, realizada em Brasília, em dezembro de 2003, e, posteriormente, com a formalização, por meio da Resolução n. 145, de 15 de outubro de 2004, no Conselho Nacional de Assistência Social - CNAS, que se instituiu uma Política Nacional de Assistência Social - PNAS, comprometida com a "materialização das diretrizes da LOAS e dos princípios enunciados na Constituição de 1998" (COUTO, YAZBECK e RAICHELIS, p. 2012, p. 60).

Com efeito, a PNAS (2004), consolida um conjunto de serviços e benefícios, pautados na articulação entre Proteção social básica (no âmbito dos $\mathrm{CRAS}^{48}$ ) e Proteção social especial - de media e alta complexidade (nos CREAS ${ }^{49}$ ). Nesta

${ }^{48}$ O Centro de Referência da Assistência Social - CRAS, "é uma unidade de proteção social básica do SUAS, que tem por objetivo prevenir a ocorrência de situações de vulnerabilidades e riscos sociais nos territórios, por meio do desenvolvimento de potencialidades e aquisições, do fortalecimento de vínculos familiares e comunitários, e da ampliação do acesso aos direitos de cidadania" (BRASIL, 2009, p.9).

${ }^{49}$ O Centro de Referência Especializado em Assistência Social - CREAS, "é a unidade pública estatal de abrangência municipal ou regional que tem como papel constituir-se em lócus de referência, nos territórios, da oferta de trabalho social especializado no SUAS a famílias e indivíduos em situação de risco pessoal ou social, por violação de direitos" (BRASIL, 2011, p. 23). E subdivide-se em proteção social de média e alta complexidade, tendo em vista as diversas constatações de violação de direitos. 
normativa, apesar de ser retirado, de seus princípios e objetivos, a promoção para a integração no trabalho, diferenciando-se da Constituição de 1988 e da LOAS, ela incorpora no campo da proteção social básica esta lógica. De acordo com a PNAS (2004), entre os serviços da proteção básica, que potencializam "a promoção da integração ao mercado de trabalho", estão os "Programas de inclusão produtiva e projetos de enfrentamento da pobreza" bem como os "Centros de informação e de educação para o trabalho, voltados para jovens e adultos" (BRASIL, 2004, p. 36).

Este destaque é importante porque, na contemporaneidade, a articulação entre estes programas e projetos, no âmbito dos CRAS, assumem protagonismo no cotidiano da intervenção socioassistencial.

Ao se implementar a PNAS, este processo traz consigo também a instituição do Sistema Único da Assistência Social - SUAS, que vai efetivamente materializar a concepção de proteção social básica e especial nos municípios brasileiros e cujo

modelo de gestão é descentralizado e participativo, constitui-se na regulação e organização em todo o território nacional das ações socioassistenciais. Os serviços, programas, projetos e benefícios têm como foco prioritário a atenção às famílias, seus membros e indivíduos e o território como base de organização, que passam a ser definidos pelas funções que desempenham, pelo número de pessoas que deles necessitam e pela sua complexidade. Pressupõe, ainda, gestão compartilhada, co-financiamento da política pelas três esferas de governo e definição clara das competências técnico-políticas da União, Estados, Distrito Federal e Municípios, com a participação e mobilização da sociedade civil, e estes têm o papel efetivo na sua implantação e implementação (BRASIL, 2004, p. 39).

Por meio da aprovação da Norma Operacional Básica do SUAS - NOB/SUAS $(2005)^{50}$, que "disciplina a gestão pública da política de assistência social no território brasileiro, exercida de modo sistêmico pelos entes federativos" (BRASIL, 2005, p. 13), implementa-se no SUAS a perspectiva da articulação com as instancias de formação e profissionalização para o mercado de trabalho. Um dos objetivos mencionados no texto da NOB/SUAS é a

50 Essa versão da NOB/SUAS foi revogada a partir da Resolução CNAS ํㅡ 33 de 12 de dezembro de 2012, que aprovou a nova Norma Operacional Básica do SUAS - NOB/SUAS. 
articulação intersetorial de competências e ações entre o SUAS e o Sistema Educacional por intermédio de serviços complementares e ações integradas para o desenvolvimento da autonomia do sujeito por meio de garantia e ampliação de escolaridade e formação para o trabalho (BRASIL, 2005, p.15).

Em 2009 o Conselho Nacional de Assistência Social (CNAS), por meio da Resolução nำ 109, de 11 de novembro de 2009, aprovou a Tipificação Nacional dos Serviços Socioassistenciais, possibilitando a uniformização no que tange a proteção social básica e especial nos municípios; estabeleceu ainda "seus conteúdos essenciais, público a ser atendido, propósito de cada um deles e os resultados esperados para a garantia dos direitos socioassistenciais" (BRASIL, 2014, p. 4), além de inserir a Inclusão Produtiva nas responsabilidades da proteção social básica, a cargo do CRAS.

A partir de 2011, com a implementação do Plano Brasil Sem Miséria ${ }^{51}$, a proteção social básica, centrada nos CRAS, se subdividiu em duas partes com status desiguais: em uma, de caráter desmercadorizado, ficou a prestação de acompanhamento com serviços continuados e de aumento da cidadania, (como os debates sobre a participação política dos usuários no campo dos direitos socioassistenciais ${ }^{52}$ ); e, em outra, de caráter mais mercadorizado, foi aplicada grande parte de incentivos financeiros e de gestão da política, voltados para a garantia da renda e o alívio imediato da situação de pobreza (por meio de programas focalizados, como o Bolsa Família). Nesta parte, ainda, estão, no âmbito dos CRAS, os cursos de profissionalização para o mercado de trabalho (é o caso do ACESSUAS-TRABALHO,

51 “É necessário entendermos também a importância desse plano, tendo em vista seu caráter contraditório, mas também de possibilidades. Segundo Yazbeck (2012), "o plano vem se desenvolvendo a partir de três eixos, a saber: 1) garantia de renda, 2) inclusão produtiva e, 3) acesso a serviços públicos. Nesses eixos estão sendo buscados a ampliação de oportunidades e o desenvolvimento de capacidades. A busca e a inserção pró-ativas no Bolsa Família será acompanhada de atividades de inserção produtiva no meio urbano (geração de ocupação e renda, micro/empreendedor individual, economia solidária, qualificação e intermediação de mão de obra) e rural (aumento da produção, água, sementes e insumos para todos, acesso aos mercados e autoconsumo). Como é possível observar, trata-se de um plano que se propõe um enorme desafio, que conjuga ações em três importantes eixos que vão configurar um feixe de mediações, em diversas escalas para penetrar essa trama social configurada pela experiência da pobreza e que não cabe em "modelos" preconcebidos" (p. 315).

52 Aqui estamos nos referindo ao cotidiano dos serviços vivenciados nos CRAS, tendo em vista que há a participação desses usuários nas Conferências municipais, estaduais e nacional de Assistência social. Entendemos, outrossim, que esses debates devem ser contínuos e recorrentemente incorporados na agenda da política sócio-assistencial. 
cursos do PRONATEC e outras ações de articulação municipal ${ }^{53}$ ), cujo protagonismo é evidente.

Esta evidência também pode ser observada na Resolução no 33, de 28 de novembro de 2011, aprovada pelo Conselho Nacional de Assistência Social, que "define a Promoção da Integração ao Mercado de Trabalho no campo da assistência social e estabelece seus requisitos". Nela, a relação contraditória entre assistência (associada ao direito) e o trabalho (associado ao mérito) assim como a ativação dos demandantes da assistência social para o mercado de trabalho estão presentes.

Está certo que, em relação à promoção para a inserção no trabalho a Resolução declare que a função primeira da política de assistência social não é esta, mas sim “ a proteção social e que a integração ao 'mundo do trabalho' não é de responsabilidade exclusiva da assistência social, mas resultado da ação intersetorial de diversas políticas públicas" (BRASIL, 2011); entretanto, uma análise mais acurada permite-nos afirmar que vários de seus dispositivos normativos transmitem, claramente, a perspectiva funcional da assistência ao atual processo de ativação dos pobres para o trabalho. Se não, vejamos a título de exemplificação:

Art. 1․ Para efeito desta resolução fica estabelecido que a promoção da integração ao mercado de trabalho no campo da assistência social deve ser entendida como integração ao "mundo do trabalho", sendo este um conceito mais amplo e adequado aos desafios da política de assistência social;

Art. 2‥ Definir que a Promoção da Integração ao Mundo do Trabalho se dá por meio de um "conjunto integrado de ações das diversas políticas cabendo à assistência social ofertar ações de proteção social que viabilizem a promoção do protagonismo, a participação cidadã, a mediação do acesso ao mundo do trabalho e a mobilização social para a construção de estratégias coletivas"

Art.3‥ Estabelecer como requisitos básicos para as ações de promoção da integração ao mundo do trabalho no âmbito da assistência social: [...] III. Atuação em grupos com foco no fortalecimento de vínculos e desenvolvimento de atitudes e habilidades para a inserção no mundo do trabalho com monitoramento durante este processo. (BRASIL, 2011).

53 Esses cursos, na sua maioria de baixa absorção pelo mercado de trabalho, são responsáveis por criar uma falsa sensação de inserção imediata do sujeito atendido no mercado de trabalho ou de individualizar a responsabilidade desse sujeito pelo desemprego. 
E o inciso III, do art. 3ำ refere-se à inserção dessas estratégias de ativação, no Serviço de Proteção e atendimento Integral à Familia - PAIF ${ }^{54}$, ou, no Serviço de Proteção e Atendimento Integral à Família a partir da tipificação nacional dos Serviços Socioassistenciais de 2009, que integra a proteção social básica no âmbito dos CRAS.

Apesar disto, o Caderno de Orientações Técnicas que se refere ao PAIF, mesmo reconhecendo a potencialidade dos seus serviços ofertados, na possibilidade da identificação de possíveis famílias para ativa-las para o trabalho, adverte que

as ações cujo foco é a inserção/inclusão produtiva, geração de renda ou capacitação/ qualificação profissionais ou ainda os denominados projetos de enfrentamento da pobreza não compõem o rol de ações do PAIF. Os programas ou projetos com esse objetivo podem ser desenvolvidos no CRAS, desde que não interfiram na adequada oferta do trabalho social com famílias, não comprometendo espaço físico e recursos humanos destinados ao PAIF (BRASIL, 2012, p. 52).

A necessidade da inclusão produtiva ou inserção produtiva que assume protagonismo nos CRAS, evoca, a partir dessas normativas, o papel institucionalizado e "sutil" de ativação a curto e médio prazos dos demandantes da assistência social para o mercado de trabalho, via cursos de profissionalização aligeirados ${ }^{55}$ ). E, com

54 "O PAIF surge no entendimento da importância do trabalho social com famílias, indo na direção histórica da superação desse trabalho entendido como caridade e introduzindo um "conjunto de procedimentos efetuados a partir de pressupostos éticos, conhecimento teórico-metodológico e técnico-operativo, com a finalidade de contribuir para a convivência, reconhecimento de direitos e possibilidades de intervenção na vida social de um conjunto de pessoas, unidas por laços consanguíneos, afetivos e/ou de solidariedade - que se constitui em um espaço privilegiado e insubstituível de proteção e socialização primárias, com o objetivo de proteger seus direitos, apoiálas no desempenho da sua função de proteção e socialização de seus membros, bem como assegurar o convívio familiar e comunitário, a partir do reconhecimento do papel do Estado na proteção às famílias e aos seus membros mais vulneráveis. Tal objetivo materializa-se a partir do desenvolvimento de ações de caráter "preventivo, protetivo e proativo", reconhecendo as famílias e seus membros como sujeitos de direitos e tendo por foco as potencialidades e vulnerabilidades presentes no seu território de vivência" (BRASIL, 2012, p. 12)

55 “Um país continental, com campos produtivos diversos e significativo número de jovens (para falarmos apenas de parte do público a que se destinam as qualificações), demanda verdadeiramente um projeto de formação que comporte, inclusive, aprendizagens dos níveis fundamentais. O modelo para tanto, porém, não pode estar limitado a aprendizagens simples e aligeiradas, frágeis na execução e na viabilização da permanência nos cursos, tal como tem ocorrido no PNQ e na proposta de inserção produtiva dos Cras. Com perfil atual, o que se efetiva e aprofunda é a perpetuação de um modelo produtivo organizado sobre a produção de bens simples e sobre 0 isolamento da produção científica em algumas poucas ilhas de excelência, gerando um plano de formação não abrangente, fragilíssimo de conteúdos, empobrecido no fazer profissional e no pensar a profissão, que aceita e aprofunda a condição de periferia produtiva do país na divisão internacional do trabalho" (LESSA, 2011, p.304). 
isso, suaviza-se a tensão entre a assistência social e o trabalho na contemporaneidade. É como diz Lessa (2011):

nessas estruturas estão contidos os contornos e as tensões da relação entre o capital e trabalho e entre projetos de formação partidos pela dualidade estrutural - para os trabalhadores, formação focada na produção, destituída de base científica e atitudinal, e para a burguesia, formação ampla, complexa e fundamentada na ciência (p. 289).

Vale dizer: uma formação pautada pela precariedade do fazer por fazer, na perspectiva de introjetar a qualquer custo a lógica da meritocracia e do sentimento de satisfação pessoal via qualquer trabalho. Essa lógica atua aqui de forma perversa, pois, a partir do momento que esses trabalhadores não dispõem dos meios de produção para a realização do seu trabalho; possuem escolaridade deficitária; e a sua mão de obra restringe-se às atividades de baixa inserção no mercado de trabalho, seu retorno ao mercado trabalho, em vez de gerar maior proteção, engendra-lhe mais sofrimentos. 


\title{
CAPITULO 4
}

\section{PROGRAMAS BRASILEIROS DE TRANSFERÊNCIA DE RENDA (PTRS) E QUALIFICAÇÃO PARA O MERCADO DE TRABALHO}

\author{
PREDOMÍNIO DA FOCALIZAÇÃO E DO MÉRITO
}

A estratégia de garantia de renda por meio de repasses monetários e condicionada a contrapartidas, tem similaridades com a lei inglesa, elisabetana, denominada Speenhamland, de 1795. Esta lei, considerada a primeira medida de transferência do mundo, exigia dos beneficiários da assistência pública a obrigatoriedade de vinculação a algum tipo de trabalho como resposta à prestação de renda que Ihes era feita pelo Estado. Desta forma, apesar de algumas diferenças, pode-se observar, nessa lei, similaridades com os programas atuais de segurança de renda, dotados de condicionalidades, dentre as quais atuais, direta ou indiretamente está incluído o trabalho.

No Brasil, esse debate acerca dos programas de transferência de renda se adensa a partir da década de 1980, tendo em vista as transformações econômicas, que influenciaram o mundo do trabalho, como o crescimento de um desemprego estrutural (SILVA; YAZBECK; DI GIOVANNI 2008, p. 41).

Definindo os programas de transferência de renda, estes podem ser identificados como

\footnotetext{
aqueles que atribuem uma transferência monetária a indivíduos ou a famílias, mas que também associam a essa transferência monetária componente compensatório, outras medidas situadas principalmente no campo das políticas de educação, saúde e trabalho, representando, portanto, elementos estruturantes, fundamentais para permitir o rompimento do ciclo vicioso que aprisiona grande parte da população brasileira nas amarras da reprodução da pobreza (idem, p. 22).
}

A adoção de uma política econômica e social destinada à "resolução" da pobreza, com orientação dos organismos internacionais, e a invasão neoliberal na 
América Latina, contribuíram para o surgimento desses programas com um corte focalizado nas populações extremamente pobres. Até a década de 1970, a instituição desses programas, eram observadas como um complemento à redução das expressões da precarização da vida na sociedade capitalista, articulando-se com o trabalho.

Stein (2000), ao se referir à inserção desse modelo de combate à pobreza afirma que as teses neoliberais referentes às políticas públicas que ganharam fôlego a partir de 1980, no Brasil, demonstram a perspectiva das reformas nos sistemas de proteção social, "orientadas para a sua privatização, fragmentação, focalização e criação de programas sociais e de emergência, dirigidos à população ou grupos “carentes” (p. 158-159). Segundo Silva; Yazbeck e Di Giovanni (2008),

em se tratando de um debate mais especifico sobre os programas de Transferência de Renda, o ano de 1991 é considerado o marco inicial desse debate, que foi, inicialmente, mobilizado pela aprovação do Projeto de Lei no 80/1991, que propõe a instituição do Programa de Garantia de Renda Mínima, em sessão do Senado Federal de 16/12/1991, de autoria do Senador do Partido dos Trabalhadores, Eduardo Suplicy (p. 32).

Mas, segundo Boschetti (2008, p.7), na situação contemporânea, os benefícios assistenciais, sob a forma de programas de transferência de renda permanentes, passaram a ter papel de "substitutos" dos rendimentos dos "empregos inexistentes". Até 2003, registrava-se a existência da implementação de programas de transferência de renda no Brasil, por meio de experiências de municípios e Estados federados, bem como de diversos programas de âmbito federal. Elenca-se no Brasil, até 2003, os programas que formavam a "rede de proteção social" quais sejam: Benefício de Prestação Continuada (BPC); Programa Agente Jovem de Desenvolvimento Social; Programa de Erradicação do Trabalho Infantil (PETI); Programa Nacional de Renda Mínima, vinculado à Educação - "Bolsa Escola"; Programa Bolsa Alimentação; Auxilio-Gás; e Cartão Alimentação. A partir de 2003, instituiu-se o Programa Bolsa Família (PBF), que unificou os programas Bolsa Escola, Bolsa Alimentação, Vale Gás e Cartão-Alimentação. 
De acordo com Silva, Yazbeck e Di Giovanni (2008), uma das características que marcam esses tipos de programas é sua índole liberal/burguesa, restringindo-se a iniciativas compensatórias e engendrando parca ou ausente relação de distributividade e de superação da desigualdade social.

Tais programas de transferência de renda estão inseridos no núcleo de proteção básica da política de assistência social, assim como as estratégias de ativação dos demandantes para o mercado de trabalho. Tem sido atribuída à assistência social a orientação de dotar seus serviços de cursos de qualificação para o mercado de trabalho, individualizando nos seus demandantes a responsabilidade pelo desemprego. Essas mudanças na proteção social - a constituição de programas de transferência de renda, bem como a ativação do beneficiário para o mercado de trabalho - têm sido profícuas na formação de um consenso entre classes, legitimando essas estratégias que deturpam a real função da política social, que seria, em vez de incentivar a inserção dos demandantes da assistência no trabalho precário e desprotegido, protegê-los de fato dos malefícios desta forma de trabalho.

Assim, após tratar do processo histórico de institucionalização da Assistência Social, este capitulo vai demonstrar, à guisa de ilustração e por meio da nossa unidade empírica de análise, constituída pelos programas Bolsa Família e o Acessuas Trabalho, os contra-sensos políticos e os dilemas concretos da relação entre a Assistência Social e o Trabalho no Brasil.

Esses programas estão, contemporaneamente, no "olho da tormenta" considerando o seu caráter contraditório, que, ao mesmo tempo em que engendra possibilidades, reafirma a lógica de transferência de renda mínima para os pobres entre os mais pobres e da individualização da responsabilidade pelo "insucesso" de sua não inserção no mercado de trabalho.

\subsection{PROGRAMA BOLSA FAMíLIA - PBF}

A estruturação de programas de transferência de renda no Brasil tem como ponto de partida a adesão do Estado a essa modalidade de proteção, a partir de 1991, com a apresentação e posterior aprovação, no Senado Federal, de um Projeto de Lei, pelo Senador Eduardo Suplicy, de criação do Programa de Garantia de Renda Mínima 
- PGRM. Tal programa era "destinado a todos os brasileiros residentes no país, maiores de 25 anos de idade que auferissem uma renda que correspondesse a cerca de três salários mínimos nos valores de 2007" (SILVA; YAZBECK; DI GIOVANNI, 2008, p.17).

No percurso da aprovação desse Programa de Garantia de Renda Mínima, foram travados alguns debates, tendo em vista a sua não aceitação pelos setores mais conservadores da sociedade e do Senado. Silveira (2002), levanta os seguintes questionamentos em relação a essa dificuldade de aceitação do programa, por parte dos detentores de capital:

vale considerar o comportamento paradoxal de alguns defensores apologéticos do capitalismo. Opõem-se à garantia de renda mínima, argumentando que ninguém deve ganhar sem trabalhar. Será que não ganham rendimentos do capital, pagos aos pequenos ou grandes que o possuem, independentemente do trabalho que executam? Nunca tiveram nem mesmo caderneta de poupança? Será que desconhecem a herança? Juros, aluguéis e lucros são elementos básicos do capitalismo, tanto em sua lógica quanto em suas manifestações reais. Um mínimo de consistência da parte de todos que apregoam tal redução de renda ao salário, exigiria a condenação do capitalismo (SILVEIRA, 1992, p. 175).

No bojo dessa problematização, percebe-se que a garantia de uma renda surge nesse cenário, para os defensores da ética capitalista do trabalho, como um incentivo ao ócio; não por acaso, no aprofundamento e aprimoramento da proposta de transferência de renda, há a inserção de regras para o acesso e permanência.

Como já mencionado, em 2003, com a unificação dos Bolsa Escola, Bolsa Alimentação, Auxílio Gás e Cartão Alimentação, no governo de Luís Inácio Lula da Silva, instituiu-se, a partir da medida provisória n¹32, de 20 de outubro, o Programa Bolsa Família, "destinado às ações de transferência de renda com condicionalidades" (BRASIL, p. 1), sendo, a referida medida provisória, transformada na Lei no 10.836 , de 09 de janeiro de 2004. A partir da sua instituição o Programa Bolsa Família foi organizado em torno de três eixos: complemento da renda; acesso a direitos; articulação com outras ações (BRASIL/MDS, 2015). De acordo com Yazbeck (2012), 
atualmente (2012) o Programa atende mais de 13 milhões de famílias em todo o território nacional nos 5.564 municípios brasileiros. Seu orçamento em 2010 alcançou 0,4 do PIB (11,4 bilhões). As últimas PNADs revelam uma questão essencial: os PTRs não retiram os beneficiários do trabalho. Inúmeros estudos e pesquisas vêm demonstrando que o impacto desses programas assistenciais sobre as famílias mais pobres, sobretudo no Nordeste, é incontestável. Ele significa basicamente mais comida na mesa dos miseráveis e compra de produtos essenciais (p. 310) (Destaque nosso).

O PBF define, a partir de um limite de renda, as famílias com perfil em situação de pobreza e em situação de extrema pobreza. Esse critério foi atualizado em 2017, sendo que famílias com renda de até $R \$ 85,00$, consideradas extremamente pobres, e famílias com renda entre $R \$ 85,01$ e $R \$ 170,00$ mensais por pessoa, com crianças ou adolescentes de 0 a 17 anos, são consideradas pobres. Guiadas por essa classificação, referenciada na renda, as estratégias do Estado voltam-se para o combate à pobreza e à extrema pobreza, com a gestão compartilhada entre estados, municípios e a União, a partir desses repasses de renda, e do acompanhamento familiar de condicionalidades na saúde e na educação ${ }^{56}$.

Seus benefícios são classificados em -básico; Variável; Variável Jovem; e para Superação da Extrema Pobreza; como apresentado na tabela a seguir:

\section{Tabela 1 - BENEFICIOS E VALORES DO PBF}

\begin{tabular}{|l|l|}
\hline Benefício Básico, no valor de $\mathbf{R} \mathbf{\$} \mathbf{8 5 , 0 0}$ & $\begin{array}{l}\text { Pago apenas às famílias extremamente } \\
\text { pobres (com renda mensal por pessoa de } \\
\text { até } \mathrm{R} \$ \mathbf{8 5 , 0 0 )}\end{array}$ \\
\hline $\begin{array}{l}\text { Benefício Variável Vinculado à Criança } \\
\text { ou ao Adolescente de } 0 \text { a } 15 \text { anos. }\end{array}$ & $\begin{array}{l}\text { Pago às famílias com renda mensal de } \\
\text { até } \mathrm{R} \$ 170,00 \text { por pessoa e que tenham } \\
\text { crianças ou adolescentes de } 0 \text { a } 15 \text { anos } \\
\text { de idade em sua composição. } \\
\text { É exigida frequência escolar das crianças } \\
\text { e adolescentes entre } 6 \text { e } 15 \text { anos de } \\
\text { idade }\end{array}$ \\
\hline
\end{tabular}

\footnotetext{
${ }^{56}$ As condicionalidades para acesso e manutenção das transferências do PBF no campo da Saúde são: "Crianças menores de 7 anos devem estar com o calendário vacinal em dia e ter o acompanhamento do crescimento e do desenvolvimento; - Gestantes devem fazer consultas de pré-natal, pelo calendário do Ministério da Saúde"; [e na Educação]: "Todas as crianças e os adolescentes de 6 a 15 anos das famílias beneficiárias devem estar matriculados na escola e ter frequência mínima de $85 \%$ das aulas; • Jovens de 16 a 17 anos devem estar matriculados na escola e ter frequência mínima de 75\% das aulas" (BRASIL, 2015, p, 10).
} 


\begin{tabular}{|c|c|}
\hline Benefício Variável Vinculado à Gestante & $\begin{array}{l}\text { Pago às famílias com renda mensal de } \\
\text { até } R \$ 170,00 \text { por pessoa e que tenham } \\
\text { grávidas em sua composição. } \\
\text { São repassadas nove parcelas mensais. } \\
\text { O benefício só é concedido se a gravidez } \\
\text { for identificada pela área de saúde para } \\
\text { que a informação seja inserida no } \\
\text { Sistema Bolsa Família na Saúde. }\end{array}$ \\
\hline $\begin{array}{l}\text { Benefício Variável Vinculado à Nutriz. } \\
\mathbf{R} \$ 39,00\end{array}$ & $\begin{array}{l}\text { Pago às famílias com renda mensal de } \\
\text { até R } \$ 170,00 \text { por pessoa e que tenham } \\
\text { crianças com idade entre } 0 \text { e } 6 \text { meses em } \\
\text { sua composição, para reforçar a } \\
\text { alimentação do bebê, mesmo nos casos } \\
\text { em que o bebê não more com a mãe. } \\
\text { São seis parcelas mensais. } \\
\text { Para que o benefício seja concedido, a } \\
\text { criança precisa ter seus dados incluídos } \\
\text { no Cadastro Único até o sexto mês de } \\
\text { vida. }\end{array}$ \\
\hline $\begin{array}{l}\text { Benefício Variável Vinculado ao } \\
\text { Adolescente. } \\
\mathbf{R} \mathbf{4 6 , 0 0} \text { (até dois por família). }\end{array}$ & $\begin{array}{l}\text { Pago às famílias com renda mensal de } \\
\text { até } R \$ 170,00 \text { por pessoa e que tenham } \\
\text { adolescentes entre } 16 \text { e } 17 \text { anos em sua } \\
\text { composição. É exigida frequência escolar } \\
\text { dos adolescentes. }\end{array}$ \\
\hline $\begin{array}{l}\text { Benefício para Superação da Extrema } \\
\text { Pobreza } \\
\text { Valor calculado individualmente para } \\
\text { cada família. }\end{array}$ & $\begin{array}{l}\text { Pago às famílias que continuem com } \\
\text { renda mensal por pessoa inferior a } R \$ \\
85,00 \text {, mesmo após receberem os outros } \\
\text { tipos de benefícios do Programa. }\end{array}$ \\
\hline
\end{tabular}

Fonte: Elaboração própria a partir do site oficial do MDSA.

Esses repasses de renda do Programa Bolsa Família entram em constante conflito com os padrões da moral burguesa que, como já referido, atribui ao trabalho e seus rendimentos o lugar da satisfação de necessidades e do mérito de cada indivíduo. A vida dos beneficiários, que já é carregada de privações múltiplas e variadas, é ainda castigada com o acesso e o usufruto dos repasses de renda estatal, tendo em vista que, com eles, se exacerba a discriminação e o ódio de classe na sociedade. Não há dúvida que, por trás do ódio atualmente manifestado contra o pobre no Brasil está presente uma guerra de classe.

É preciso, portanto, a compreensão de que esta questão não é episódica e superficial, mas é enraizada na secular cultura brasileira que nunca se desvencilhou de seu passado escravocrata. Uma cultura que se entranha no senso-comum, e se alimenta de ideologias e posições políticas ligadas a mentalidade colonizadora. 
As raízes dessa questão, de ódio de classe, que se estende ao ódio racial (não esquecer que a maioria dos pobres é negra), pode ser observada, desde a saída do regime escravocrata que, como já mencionado, deixou para os negros, após a abolição da escravatura e a entrada no regime de trabalho "livre", os trabalhos braçais e de cunho punitivo, sem nenhum tipo de reparação ou proteção. Reafirmando esse entendimento, com base nas elaborações de Fernandes (2006), ao descrever o processo da "Revolução Burguesa", constatamos o ódio de classe e o lugar destinado à classe trabalhadora pela burguesia no Brasil. Segundo ele,

à oligarquia a preservação e a renovação das estruturas de poder, herdadas no passado, só interessavam como instrumento econômico e político: para garantir o desenvolvimento capitalista interno e sua própria hegemonia econômica, social e política. Por isso, ela se converteu no pião da transição para o "Brasil moderno". (...) Só ela podia oferecer aos novos comensais, vindos dos setores intermediários, dos grupos imigrantes ou de categorias econômicas, a maior segurança possível na passagem do mundo pré-capitalista para o mundo capitalista, prevenindo a "desordem da economia", a "dissolução da propriedade" ou o "desgoverno da sociedade". Também foi ela que definiu o inimigo comum: no passado, o escravo (e, em sentido mitigado, o liberto); no presente, o assalariado ou semiassalariado do campo e da cidade (p. 247).

Os dados do Censo Demográfico de $2010^{57}$ são profícuos ao demonstrar que $71 \%$ dos extremamente pobres no Brasil são negros. Em vista disso, podemos inferir que a maioria da classe trabalhadora no Brasil também é formada por negros; e mais, de acordo com o MDS (2013), "das 13,8 milhões de famílias atendidas pelo programa, $73 \%$ se autodeclaram pretas ou pardas". Fica claro, portanto, que a materialização do critério do mérito, a partir da ética capitalista do trabalho, é extremamente punitiva para a classe trabalhadora e negra no Brasil, pois esta já padece, pelo seu passado enraizado de mão de obra escrava e servil, de tratamentos discriminatórios na atualidade, que se somam aos conflitos inerentes à relação trabalho assalariado $X$ proteção social.

Desta forma, Fernandes (2008) contribui com o seguinte pensamento:

\footnotetext{
${ }^{57}$ Disponível em: http://censo2010.ibge.gov.br
} 
na ânsia de prevenir tensões raciais hipotéticas e de assegurar uma via eficaz para a integração gradativa da "população de cor", fecharam-se todas as portas que poderiam colocar o negro e o mulato na área dos benefícios diretos do processo de democratização dos direitos e garantias sociais. Pois é patente a lógica desse padrão histórico de justiça social. Em nome de uma igualdade perfeita no futuro, acorrentava-se o "homem de cor" aos grilhões invisíveis de seu passado, a uma condição subhumana de existência e a uma disfarçada servidão eterna (p.309).

Portanto, não há possibilidades de se falar em meritocracia, trabalho e proteção social no Brasil sem se atentar também para os fatores determinantes que a raça impõe. Seja porque é ainda recente a história da escravidão no Brasil, porque as influencias desse passado recente perduram até os dias atuais, seja pelo acesso precário dos pobres no mercado de trabalho e pela luta difícil por uma proteção social que leve em conta essas particularidades.

O Programa Bolsa Família, apesar de pretender vir na contramão de um processo de reprodução da pobreza, que exclui os trabalhadores e majoritariamente, como demonstrado, negros no Brasil, do acesso à renda - podendo ser observado como uma primeira possibilidade de questionamento dos efeitos deletérios do trabalho precário - está longe de possibilitar grandes mudanças de forma duradoura na vida de seus beneficiários. Primeiro porque os valores dos repasses são irrisórios e também porque no centro dessa dinâmica está a lógica do modo de produção capitalista, que inclui para explorar e exclui para sua manutenção. Além disso, como afirma PereiraPereira (2013),

[...] no capitalismo, a proteção social sempre foi funcional ao processo de acumulação, embora contraditoriamente ela tenha constituído um meio de defesa dos trabalhadores contra a exploração exacerbada do capital. Pode-se até mesmo afirmar que o objetivo do bloco no poder que a cultiva e a regula não é propriamente o alívio da pobreza, embora a palavra relief esteja na moda; mas, de um lado, regular os conflitos gerados pelo desemprego e, de outro, manter e reforçar o trabalho assalariado de baixa remuneração, útil ao aumento do consumo, cada vez mais incentivado pela ampliação dos sistemas de créditos (p. 645). 
É inegável, como já salientamos, a importância que o PBF assumiu na realidade duradoura da fome, no Brasil, como demonstra o "relatório de insegurança alimentar no mundo de 2014" publicado pela Organização das Nações Unidas para a Alimentação e a Agricultura (FAO); mas, apesar de sua contribuição na redução dessa realidade, os níveis de desigualdade ainda se adensam. Segundo Boschetti (2012), a partir do,

\begin{abstract}
documento do PNUD/ONU, o Brasil apresenta o terceiro pior índice de desigualdade do mundo. [...] Os festejados crescimento econômico e redução da pobreza, portanto, escondem a drástica e persistente desigualdade entre ricos e pobres, as imensas distâncias entre o menor e o maior salário vigentes, a aguda e inaceitável concentração de terra, agravada nos últimos dez anos, o reduzido acesso às políticas sociais, a precarização das condições de trabalho, 0 desemprego e subemprego de mais de metade da população economicamente ativa, a violação cotidiana e bárbara dos direitos humanos, a baixa qualidade da saúde, educação e moradia (BOSCHETTI, 2012, p. 48).
\end{abstract}

Nessa direção, a construção ideológica na opinião pública, da necessidade de políticas sociais tem centralidade na superficialidade da pobreza, ou seja, nos seus "sintomas" aparentes e não na dinâmica estrutural que fundamenta a desigualdade social, tendo em vista que o trabalho assalariado seria um "alinhador" de oportunidades e, portanto, o parâmetro de bem-estar a seguir.

Sendo assim, programas sociais não devem se basear pela lógica da universalidade, mas, por um corte de renda que limite o acesso e/ou "incentivo ao ócio", além de implementar contrapartidas para o acesso e permanência. Essas contrapartidas são amplamente absorvidas e defendidas pelos seus demandantes, criando um discurso punitivo que legitima a meritocracia e a ética capitalista do qualquer trabalho.

No PBF, há a recorrente busca por maior focalização e regressividade dos repasses monetários, buscando ativar para o mercado de trabalho quem permanece no programa e enraizando ainda mais a condição de subcidadãos imposta pela opinião pública, mídia e partidos conservadores aos beneficiários. 


\subsection{PROGRAMA ACESSUAS - TRABALHO}

O Programa Nacional de Promoção do Acesso ao Mundo do Trabalho ACESSUAS - TRABALHO, instituído pelo Conselho Nacional de Assistência Social/CNAS (Resolução № 18 de 24 de maio de 2012), tem como principal finalidade, "promover o acesso dos usuários da Assistência Social ao mundo do trabalho" (BRASIL, 2012, p.7). Com esse propósito ele tem se tornado umas das principais estratégias (em compartilhamento com os programas de transferência de renda) no âmbito da proteção básica da política de Assistência Social, que suprime a oferta de serviços socioassistenciais, substituindo-os pela ativação do para o trabalho assalariado. Desta forma, a assistência social tem se tornado a porta de saída dos usuários para o mercado de trabalho.

Essa resolução que institui o ACESSUAS-TRABALHO, seguindo as orientações da resolução CNAS no 33/2011, citada em capitulo anterior, define que a promoção da integração ao mundo do trabalho que se vincula à assistência social, terá a integração com as demais políticas, mas, cabendo a "Assistência Social viabilizar a promoção do protagonismo, a participação cidadã e a mediação do acesso ao mundo do trabalho" (BRASIL, 2012, grifo nosso).

Este Programa, que foi inicialmente pensado para funcionar no período de 2012 a 2014, teve a sua duração estendida até 2018; ou seja, o processo de "qualificação de mão-de-obra" no âmbito da Assistência Social, vai buscando perpetuação o que pode descaracterizar a concepção de proteção básica instituída a partir da PNAS (2004) e do SUAS (2005). Ele faz parte das estratégias do Estado, no âmbito do Programa Brasil Sem Miséria, para superar a extrema pobreza, e, como seria de esperar, é limitado. Encarado nas regulamentações como estratégia de "superação" da indigência, foca tão somente nas conseqüências desta, como a ausência da renda da população pauperizada dada à falta de um trabalho assalariado, e não nos processos estruturais da produção e reprodução da pobreza.

Essa pobreza a qual nos já referimos como multidimensional, está atrelada segundo Yazbeck (2012), a "uma condição de classe" e,

como categoria histórica e socialmente construída, como fenômeno que não pode ser tomado como natural. Estamos também nos 
reportando à qualidade relativa da pobreza, que gira em torno da desigualdade social, assim como a outras condições reiteradoras da desigualdade (como gênero, etnia, procedência e outros aspectos) ( $p$. 290).

Os objetivos e metas do PBSM são classificados em: "acesso a Serviços (que incluem educação, saúde, assistência social e segurança alimentar); Garantia de Renda; e Inclusão Produtiva" (BRASIL, 2012, p. 11). Desta forma, o programa ACESSUAS - TRABALHO, enquanto estratégia para a formação da mão-de-obra se insere no núcleo da inclusão produtiva urbana.

Esta inclusão ou inserção produtiva é a estratégia contemporânea que se insere na assistência social, para a promoção da inserção dos usuários no mercado de trabalho. Aproxima-se das aspirações da sociedade quando exigem uma contrapartida para o acesso ao direito, respondendo com cursos de profissionalização sob a expectativa de que, com eles, as chances de saída da "dependência" da assistência seriam maiores. Pereira-Pereira (2013), em relação a essa concepção de se confundir o trabalho assalariado como um direito, afirma que,

no capitalismo, o trabalho assalariado, para se reproduzir, não precisa ser elevado à condição de direito, pois a própria dinâmica do capital se encarrega de ativar esse trabalho entre outras formas de exploração humana, inclusive com a contribuição das políticas sociais, agora usadas na contramão da cidadania, como: a educação, que atualmente se degrada ao ficar restrita a adequar formação de recursos humanos às demandas do mercado de trabalho e a treinar desempregados para a sua reinserção neste mercado ou em atividades economicamente produtivas; a previdência, que está sendo restringida a mero seguro; a saúde que está se transformando em mercadoria a olhos vistos; e a assistência, que se degrada por sua dupla qualificação perversa: como relief (alívio da pobreza) e como agenciadora de força de trabalho pouco qualificada para o mercado de trabalho e de consumo de massa.

Segundo o Caderno de Orientações Técnicas do Programa Nacional de Promoção do Acesso ao Mundo do Trabalho - ACESSUAS - TRABALHO (2012), este Programa tem como objetivo - vale repisar - a inserção dos usuários da Assistência Social no mercado de trabalho. E sua implementação é feita a partir da pactuação com as Secretarias de Assistência Social dos municípios e do DF e com as Secretarias 
da Assistência Social dos Estados, que devem fornecer os subsídios técnicos para a sua operacionalização nos municípios (BRASIL, 2012, p. 7).

Os seus recursos têm como origem o governo federal, por meio do fundo da assistência social; ou seja, há repasse do fundo nacional para o fundo municipal, por meio da adesão dos governos municipais e pactuação com os conselhos municipais. É necessário ressaltar, que segundo esse Caderno, as ações de inserção dos usuários ao mundo do Trabalho não são exclusivas da Assistência Social, mas resultado de um processo intersetorial.

Neste mesmo sentido, e consideradas as contradições que perpassam esse processo, é interessante ressaltar o que a Resolução que institui o programa, aprovada pelo CNAS, afirma,

O Programa propõe o desenvolvimento de ações de articulação, mobilização e encaminhamento de pessoas em situação de vulnerabilidade e, ou risco social para garantia do direito de cidadania a inclusão ao mundo do trabalho, por meio, do acesso a cursos de qualificação e formação profissional, ações de inclusão produtiva e serviços de intermediação de mão de obra. Incluem ainda, ações de articulação com outras políticas públicas para superação das vulnerabilidades sociais (BRASIL, 2011, grifos nossos).

Contudo, ressalvadas a importância do trabalho assalariado para a sobrevivência dos indivíduos, no modo de produção capitalista - porque sem ele a alternativa, em última instância, é a morte - torna-se difícil considerar o trabalho assalariado nesse modo de produção, como um "direito de cidadania". Embora seja inegável as conquistas alcançadas pelos trabalhadores por meio do trabalho assalariado em contexto mundial, constitui uma impropriedade considerá-lo um direito de cidadania tendo em vista a sua condição de exploração e desumanização da humanidade do trabalhador que vê transformada a sua vida sadia num cotidiano de estiolamento físico e mental, pelos riscos, mecanização de comportamentos e extenuação.

De acordo com o PPA 2012-2015 (2011), com o processo de "expansão econômica" que o Brasil vivenciou na contemporaneidade, com as mudanças nos processos tecnológicos e produtivos, cresceu a necessidade da formação da mão-deobra, dada a sua escassez, tendo em vista a demanda do setor produtivo. 
Este momento traz consigo a exigência de uma educação profissional e tecnológica que atenda às demandas do mercado de trabalho, mas também que forme um profissional capaz de compreender a realidade que o cerca, de ultrapassar obstáculos e de pensar e agir em prol das transformações políticas, econômicas, culturais e sociais imprescindíveis à construção de um país menos desigual e mais justo (BRASIL, p.145).

Entretanto, o que se tem observado nesses cursos de qualificação, via assistência social, é a sua realização aligeirada, fruto de uma dinâmica acrítica; e a ausência da contextualização da crise do capital que afeta diretamente o mundo do trabalho e poderá desconstruir o processo de responsabilização individual dos demandantes pelo contexto de desemprego.

Conforme Boschetti (2009a), para a avaliação de programas, é interessante fazer alguns destaques do programa em questão, tentando demonstrar suas perspectivas e tendências, como: a sua configuração e abrangência; os critérios de permanência dos usuários e as possibilidades de articulação com as demais políticas. Além disso, cabe analisar como a gestão do programa se relaciona com os processos de controle democrático (BOSCHETTI, idem, p. 14), observando se os demandantes têm poder de decisão nos cursos de qualificação.

Os municípios do Brasil ainda padecem de uma cultura de dominação que perpetua a precarização da vida da maior parte da população, tais como: coronelismo, clientelismo, paternalismo, processos que ainda são bastante presentes na política de Assistência Social (apesar do esforço de sua institucionalização). Essa cultura do não direito, segundo Oliveira (2003, p.82), encontrou "[...] terreno fértil para sua expansão, estabelecendo formas de relação entre Estado e sociedade pautados no personalismo, na reciprocidade de benefícios e na lealdade particularista".

Como este é um Programa que se insere na Assistência Social, política não contributiva, ele não depende de prévia contribuição do usuário, mas, tem sua abrangência limitada, tendo em vista a prioridade que tem se estabelecido na proteção social básica para acesso aos programas; tal é o caso da sua articulação com os beneficiários do Bolsa Família e demais programas citados na seção referente aos usuários. Somam-se ainda as poucas vagas destinadas aos municípios e o jogo de 
favores para acesso a essas vagas, observado em dias de matrícula para o acesso ao curso.

A sua operacionalização prevê a formação de parcerias e repasses para a formação profissional a partir dos programas Pronatec/BSM; Mulheres Mil; Intermediação Pública de Mão de Obra; Economia Popular e Solidaria; Microempreendedores Individuais; Microcrédito Crescer (Programa Nacional de Microcrédito); ABRAS (Associação Brasileira de Supermercados) e a CBIC (Câmara Brasileira da Indústria da Construção). Seu fluxo prevê a seguinte de movimentação:

\section{Figura 1- Fluxo de Atuação do Programa}

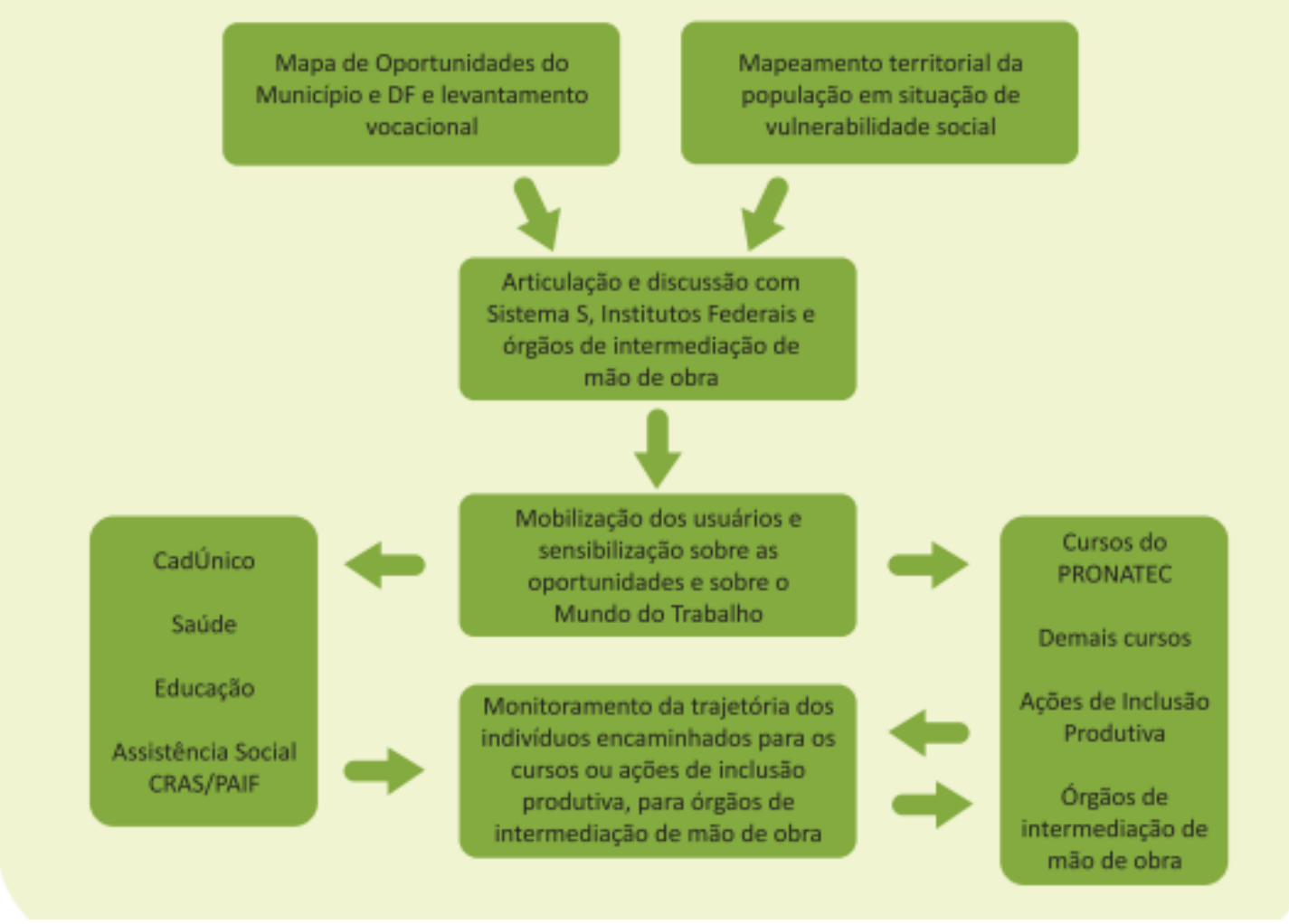

Fonte: caderno de orientações técnicas MDSA.

Todavia, no que tange a essa diagramação é necessário um alerta, tendo em vista a aprovação de algumas mudanças em relação ao Programa, sob o governo pós impeachment da presidenta eleita Dilma Roussef, de forte filiação neoliberal. Segundo 
o site do MDSA ${ }^{58}$, o Conselho Nacional de Assistência Social, aprovou na data de 15/12/2016,

novas medidas para inclusão dos beneficiários do Bolsa Família no Programa Nacional de Promoção do Acesso ao Mundo do Trabalho (Acessuas Trabalho). A alteração vai qualificar as ações da Política Nacional de Assistência Social e facilitar o acesso da população mais pobre ao mercado de trabalho. A decisão desvincula o Programa Nacional de Acesso ao Ensino Técnico e Emprego (Pronatec) do Acessuas Trabalho. Com isso, será possível a criação de outras ações de inclusão produtiva e desenvolvimento local - o que vai ao encontro da estratégia nacional que está sendo desenvolvida pelo Ministério do Desenvolvimento Social e Agrário (MDSA).

Essas adequações e mudanças no âmbito do Programa demonstra o seu caráter de permanência e aprofundamento nas ações da assistência social. Ao analisar a legislação que o regulamenta e que delimita o público alvo, podemos também confirmar seu caráter focalizado, posto que se destina a

famílias e indivíduos com perfil do Plano Brasil Sem Miséria; Jovens egressos do Serviço de Convivência para jovens; Pessoas com deficiência, beneficiárias do BPC; Pessoas inscritas no CadÚnico; Egressos do Sistema Socioeducativo; Famílias com presença de Situação de Trabalho Infantil; População em Situação de Rua; Famílias com crianças em Situação de Acolhimento Provisório; Adolescentes e Jovens Egressos do Serviço de Acolhimento; Indivíduos e famílias moradoras em territórios de risco em decorrência do Tráfico de Drogas; Indivíduos egressos do Sistema Penal; Beneficiários do Programa Bolsa Família; Pessoas retiradas do trabalho escravo; Mulheres vítimas de violência; entre outros, para atender especificidades territoriais (BRASIL, 2012, p.15).

A realização dos cursos de qualificação tem articulação tanto com a Assistência Social, tendo como órgão federal o Ministério do Desenvolvimento Social e Combate à Fome - MDS, quanto com a política de Educação do Ministério da Educação - MEC.

58 Em alguns lugares da dissertação nos referimos ao atual Ministério do Desenvolvimento Social e Agrário - MDSA, como Ministério do Desenvolvimento Social e Combate à Fome - MDS, tendo em vista que esta fusão entre a área social e agraria só ocorre com o processo de Impeachment da presidenta Dilma Rousseff, entendendo que o governo que se instala no país após esse processo, defende potencialmente uma política neoliberal de privilegiamento a outras áreas, como as que geram dividendos diretos para o capital e entende o campo da assistência como inferior, portanto, passível de junções ministeriais esdruxulas, com programas que remontam o período que se encarava a assistência como o lugar da caridade, vide o programa "Criança Feliz". 
Mas, essa articulação encontra limites na esfera municipal, já que as outras políticas não reconhecem esse Programa como de sua responsabilidade.

A destinação de recursos do ACESSUAS - TRABALHO baseia-se no "cálculo do componente básico e do componente adicional". Segundo o MDS, o componente básico "consiste no cálculo da meta pactuada, que leva em consideração o número de pessoas mobilizadas, vezes o valor de referência, com valor mínimo de repasse que é de $36 \mathrm{mil} / \mathrm{ano}$.

\begin{tabular}{|l|l|}
\hline \multicolumn{2}{|c|}{ Tabela 2- Destinação de recursos/Calculo básico } \\
\hline - No de pessoas & - Valor de Referência \\
\hline - Até 600 & - $\mathrm{R} \$ 90,00$ \\
\hline - De 601 a 1.000 & $-\mathrm{R} \$ 45,00$ \\
\hline - Mais de 1.000 & - $\mathrm{R} \$ 23,00$ \\
\hline
\end{tabular}

"Já o componente adicional é composto por duas variáveis - a primeira relaciona o número de pessoas encaminhadas, com matricula realizada, e a segunda o número de pessoas com deficiência matriculadas no Pronatec, multiplicando-se por $\mathrm{R} \$: 70,00$ reais".

\begin{tabular}{|}
\begin{tabular}{|l|l|}
\hline Tabela 3- Destinação de recursos/calculo adicional \\
\hline No de matrículas realizadas & Valor de Referência \\
\hline Até1.000 & $\mathrm{R} \$ 80,00$ \\
\hline De 1.001 a 2.000 & $\mathrm{R} \$ 40,00$ \\
\hline Mais de 2.000 & $\mathrm{R} \$ 20,00$ \\
\hline
\end{tabular} Fonte: original retirado do site oficial do MDSA \\
\hline
\end{tabular}

Por meio da adesão dos gestores municipais ao Programa, haverá o repasse anual dos recursos do Fundo Nacional da Assistência Social para o Fundo Municipal. É importante que não se confunda esses fundos - que são especiais, e "previstos no 
artigo 71 da Lei no 4.320, de 17 de março de 1964 e no artigo 165 da Constituição Federal (CF) de 1988, que se refere às instâncias de financiamento específicas na administração pública" (SALVADOR e TEIXEIRA, 2014, p.17) - com a categoria fundo público ${ }^{59}$.

A descentralização dos recursos realizada por meio do fundo nacional da assistência social para o fundo municipal, com vistas à operacionalização do Programa, toma como base o número de matriculas realizadas nos cursos de qualificação, de forma regressiva, no sentido de que: quanto mais matriculas realizadas mais o valor repassado diminui; e isso contribui para uma baixa qualidade da contratação dos serviços de qualificação e para o aumento da despesa da receita municipal. Desta forma, os municípios recebem uma carga maior de responsabilidade na condução do Programa, tendo em vista a sua autonomia como entes federados ${ }^{60}$, e o fato de que é município que, em sua maioria, organiza, articula, operacionaliza e presta contas do processo de qualificação.

A gestão do Programa é realizada através da pactuação das responsabilidades entre cada ente federado. Como já mencionado, o Governo Federal descentraliza os recursos para os municípios por meio do Fundo Nacional da Assistência Social, para o Fundo Municipal de Assistência Social. Já os Estados, são responsáveis pelos subsídios técnicos das políticas de inclusão produtiva; ficando os municípios com a maior responsabilidade que seria: organizar, mobilizar, encaminhar os usuários para a realização desses cursos de qualificação e, em alguns casos, contratar prestadores de serviços para a realização dos cursos. Sobre essas responsabilidades ver quadro a seguir.

59 De acordo com Behring (2010), "o fundo público se forma a partir de uma punção compulsória - na forma de impostos, contribuições e taxas - da mais-valia socialmente produzida, ou seja, é a parte do trabalho excedente que se metamorfoseou em lucro, juro ou renda da terra e que é apropriado pelo Estado para o desempenho de múltiplas funções. O fundo público atua na reprodução do capital, retornando, portanto, para seus segmentos especialmente nos momentos de crise; e na reprodução da força de trabalho, a exemplo da implementação de políticas sociais" (p. 20). E ainda segundo Salvador (2012), "o fundo público envolve toda a capacidade de mobilização de recursos que o Estado tem para intervir na economia, seja por meio das empresas públicas, pelo uso das suas políticas monetária e fiscal, assim como pelo orçamento público" (p. 126).

60 Em relação ao pacto federativo Arretche (1997) afirma que "enormes diferenças entre estados e municípios brasileiros quanto à capacidade técnica de absorção de novas funções constituem ainda sérios obstáculos à descentralização em qualquer de suas vertentes. Estas evidências reforçam a ideia de que ainda não se pode falar de um novo modelo, mas apenas e tão-somente da crescente consolidação de um arcabouço de medidas do governo federal destinadas a dar um formato descentralizado à gestão de suas políticas" (ARRETCHE, p.22). 
Tabela 4- Responsabilidades dos Entes federados

\section{MDS}

-Coordenar

nacionalmente

Programa

-Cofinanciar as ações do

Programa

-Produzir e divulgar orientações técnicas;

-Apoio acompanhamento monitoramento

Programa no Distrito Federal.
ESTADOS

-Apoio técnico ao

- município, principalmente em relação à articulação com diversos setores e políticas

-Acompanhamento técnico, monitoramento

e execução do Programa do nos municípios.

\section{MUNICIPIOS E DF}

-Executar as ações do Programa

-Acompanhar e

monitorar o alcance das metas estabelecidas

para 0 Programa

e -Manter sistema de

da acompanhamento do programa atualizado.

fonte: site oficial do MDSA

Por ser pontual e descontínuo, já que, a cada processo de formação os usuários mudam, o Programa, impõe sérios dilemas para o processo de controle democrático e organização dos usuários. Na sua maioria, as mobilizações buscam por mais vagas ou outros tipos de curso, ficando o questionamento sobre o porquê da realização dessa proposta de qualificação ou sobre a responsabilização e individualização, que é imposta aos usuários por não dispor de trabalho, fora das ementas desses cursos de qualificação.

O Programa Acessuas - Trabalho, deixa explicito no seu marco institucional, sua função de ativar para o mercado de trabalho, não oferecendo grandes mudanças nem na vida do demandante da assistência social, nem na dinâmica do mercado de trabalho em que se insere. Seus cursos não proporcionam grandes perspectivas de inserção num mercado de trabalho que possibilitará uma escala ascendente de prosperidade para a família dos participantes, seja por que em tempos de crise o mercado de trabalho não absorve estes trabalhadores, ou seja porque, para a manutenção do modo de produção capitalista estes trabalhadores permanecerem na condição de sobrantes é interessante, haja vista a dinâmica da lei de salários (os critérios para se manter salários indignos), com base na baixa oferta e grande procura. 


\section{CONSIDERAÇÕES FINAIS}

No primeiro capítulo desta dissertação, apontamos a necessidade de partir das especificidades materiais que compõem a realidade das sociedades no modo de produção capitalista, como também o movimento real do nosso objeto de estudo. $E$, para isto, a compreensão e adoção do método histórico-dialético, possibilitou o estudo da totalidade e do processo muldeterminado que englobam essa realidade. Nesse contexto, o estudo da categoria "contradição" dialética tem protagonismo, pois é o seu trato que fará com que não caiamos em analises superficiais que mais deturpam, estabilizando-se na dimensão fenomênica do objeto, do que conferem fidedignidade à análise do real ${ }^{61}$.

Então, é com a firmeza dos marcos da história que permeia e confere materialidade a assistência social que compreendemos que essa política não tem as capacidades necessárias para emancipar seus demandantes ou mesmo para superar as imposições da estrutura do capital. Como sinalizamos, esta consegue apontar algumas vicissitudes decorrentes dessa dinâmica e aglutinar esforços próprios e das demais políticas para servir como um limite da degradação, provendo capacidades básicas de manutenção da vida dos seus demandantes.

Por outro lado, também compreendemos que o Trabalho no modo de produção capitalista, ao mesmo tempo em que confere possibilidades mínimas de vida para os que vendem sua força de trabalho a partir do assalariamento, engendra adoecimento e encurta a vida.

\footnotetext{
${ }^{61}$ É interessante frisar isto, porque a conclusão nunca é um fim em si mesma. Na verdade, o percurso e as interrogações que se constroem e se reconstroem, a partir das afirmações em torno do objeto, são as principais conclusões, apesar de apontarmos nas considerações finais as aproximações do objeto que foram apreendidas. Talvez isto tenha uma ligação, ou seja, um desdobramento engendrado pelo método que aqui se adotou. NETTO (1988), aponta que Marx ao discutir o "método ele o faz sempre conectando a discussão do método a um objeto preciso. Isso por uma razão óbvia: na medida em que põe a teoria como reprodução ideal do movimento real do objeto, a relação do sujeito que queira reproduzi-lo (o objeto) não pode ser aleatória, mas deve ser uma relação determinada, numa perspectiva que permita apreender a dinâmica do objeto. Assim, antes que um conjunto de regras formais e intelectivas, como ocorre, por exemplo, com a sociologia positivista de Durkheim, ou antes que a prescrição de procedimentos para a construção de modelos ideal-abstratos, como a sociologia compreensiva de Weber, a questão metodológica aparece em Marx como aquela relação reflexiva que permite ao sujeito apropriar-se da dinâmica do objeto" (79).
} 
Não obstante, partimos das relações mais visíveis, ora de sintonia, ora de tensão entre a Assistência Social e Trabalho no modo de produção capitalista, para chegar à conclusão de que está havendo uma interpretação equivocada quando está em disputa a concepção da categoria "direito". Nesta perspectiva, verificamos que a ética capitalista do trabalho, que é predominante na sociedade contemporânea, contribui para esse desvio de concepção, ou seja, do que seria ou não direito.

O espraiamento dessa ética, no rastro da perspectiva político-econômica liberal, engendra na sociedade a sensação de satisfação e dignidade sempre quando é o trabalho assalariado o provedor das necessidades básicas, bem como o fim principal do assalariamento - o consumo. Desta forma, o trabalho assalariado é manifestado e privilegiado como um direito, independendo da sua condição e/ou imposição na vida dos trabalhadores, e de outro lado, a assistência social, por não depender de contribuições e não delimitar obrigações para a provisão dos seus serviços, se configura como um um incentivo à ociosidade.

Ao se compreender o trabalho assalariado no modo de produção capitalista como um direito, mediador único de bem-estar, cria-se a histórica hierarquização trabalhadores (merecedores de proteção) e os desempregados ou não inseridos em atividades laborativas (não merecedores).

Na perspectiva da Assistência Social, apesar do seu esforço histórico para se constituir como um direito social, como verificamos a partir do seu processo de instiucionalização pós 1988, afastando-se de práticas tradicionais da caridade, ela é encarada como política social necessária, mas, indesejada; isso porque, quando não se norteia, via de regra, pelo senso-comum que que mecanicamnete reifica a ética do qualquer trabalho, legitima a exclusividade do trabalho assalariado como fonte privilegiada de bem-estar. Nesta conjuntura, a lógica da meritocracia vinculada ao "esforço próprio", por meio do trabalho criador de mais valia, é quem dita quem tem ou não direito ao suprimento de suas necessidades.

Pereira-Pereira (1996), ao se referir a relação entre neoliberalismo e política pública, afirma que estes conceitos em muitos casos se apresentam como "excludentes, ou, no mínimo, inconciliáveis"62 (p. 129). E acrescenta, "isso porque,

62 “Entretanto, política pública e neoliberalismo não são tão inconciliáveis quanto parece. Se prestarmos mais atenção, veremos que muitas propostas neoliberais tem, em certa medida, apresentado pontos 
enquanto as políticas públicas são rapidamente associadas ao Estado, o neoliberalismo é associado ao mercado" (idem). Esta concepção é uma das faces que amparam a ética capitalista do trabalho, impondo exclusividade nas ações do Estado, de "tarefas especificas de policiamento, segurança pública, justiça, preservação da moeda e assessoramento técnico, e às políticas públicas, caberiam atividades restritas de atendimento focalizado e seletivo a demandas e necessidades sociais" (idem).

É guiado por esse ideário que programas ultrafocalizados na pobreza se consolidam, como é o caso do PBF, que delimita a necessidade do acesso e permanência a partir de um corte de renda mínimo; e que apesar de transformar o cenário da fome no país, não altera a sujeição destes usuários a um mercado de trabalho precário; pois, só com um assalariamento ínfimo poderão eleger-se à obtenção da renda do programa.

Nesta mesma direção, procede a inserção de cursos de qualificação no âmbito da proteção social básica da assistência social, de caráter aligeirado; sem a dimensão crítica que os possibilite a refletir sobre a conjuntura da dinâmica do mercado de trabalho, no país, a formação de mão-de-obra precária de fácil exploração é o que se Ihes oferece. Mas, mesmo assim, o mercado de trabalho já não os absorve; tais cursos têm servido como estratégia de "ativação" dos demandantes da assistência para o trabalho assalariado, mal protegidos e mal pagos.

A Inclusão ou inserção produtiva, que é incentivada pelas normativas da política de Assistência Social, contribui para aproximar essa política à concepção de direito que é imposta pela ética capitalista do trabalho, deixando-a "mais aceitável" e empurrando a curto, médio e longo prazos os demandantes da assistência para o mercado de trabalho precário. Podemos, assim, afirmar que é a face punitiva, observada na junção trabalho assalariado x assistência social, que é imposta pelo

convergentes com teses estruturalistas, ou contrarias ao neoliberalismo, quando igualmente defendem o combate à pobreza extrema, a reforma do Estado, a racionalização do gasto público, a consolidação da democracia, a reestruturação das políticas e dos serviços sociais, a descentralização político administrativa, a articulação entre Estado e sociedade na busca de soluções para os problemas sociais etc. $O$ que distingue as duas visões de mundo são o modo de operacionalizar as teses defendidas e os objetivos pretendidos por cada uma delas [...] "Mesmo assim, as políticas públicas não estão infensas às manipulações neoliberais. Tanto isso é verdade que tais políticas fizeram e ainda fazem parte de experiências guiadas pelo ideário neoliberal em vários países que o adotaram como referência" (PEREIRA-PEREIRA, 1996, p. 130). 
capital para sua manutenção e retroalimentação ${ }^{63}$ por via da intervenção social do Estado.

Para melhor percebermos essa tendência punitiva em que está em jogo o social, podemos nos remeter a Loic Wacquant (2001) quando este se refere ao Estado-Penitência ${ }^{64}$ na realidade norte-americana e europeia, a saber:

a chave da prosperidade norte-americana, e a solução para o desemprego de massa, residiria numa formula simples, para não dizer simplista: menos Estado. É verdade que os Estados Unidos - e depois deles o Reino Unido e a Nova Zelândia - reduziram fortemente seus gastos sociais, virtualmente erradicaram os sindicatos e podaram vigorosamente as regras de contratação, de demissão (sobretudo), de modo a instituir o trabalho assalariado dito flexível como verdadeira norma de emprego, até mesmo de cidadania, via a instauração conjunta de programas de trabalho forçado (workfare) para os beneficiários da ajuda social (p. 77).

Essa face punitiva de redução da interferência do Estado no campo social, que encontra qualquer saída ou meio de prosperidade apenas pelo trabalho assalariado, mesmo em tempos de profunda crise do capital como a atual, é a que se adota no Brasil. Para a resolução dessa crise, implementam-se medidas neoliberais ${ }^{65}$; se houve

63 "A acumulação perpetua a uma taxa composta depende da disponibilidade permanente de reservas suficientes de acesso à força de trabalho. O que Marx chama de "exército industrial de reserva" é, portanto, uma condição necessária para a reprodução e a expansão do capital. Esse exército de reserva deve ser acessível, socializado e disciplinado, além de ter as qualidades necessárias (isto é, ser flexível, dócil, manipulável e qualificado quando preciso). Se essas condições não forem satisfeitas, então o capital enfrenta um sério obstáculo À acumulação continua" (HARVEY, 2011, p. $55)$.

64 "[...] mais do que o detalhe dos números é a lógica profunda dessa guinada do social para o penal que é preciso apreender. Longe de contradizer o projeto neoliberal de desregulamentação e falência do setor público, a irresistível ascensão do Estado penal americano é como se fora o negativo disso - no sentido de avesso mas também de revelador -, na medida em que traduz a implementação de uma política de criminalização da miséria que é complemento indispensável da imposição do trabalho assalariado precário e sub-remunerado como obrigação cívica, assim como o desdobramento dos programas sociais num sentido restritivo e punitivo que lhe é concomitante" (WACQUANT, 2001, p. 96).

65 Uma ponderação interessante acerca da adoção do modelo de intervenção neoliberal em momentos de crise, podemos verificar em Harvey (2011), ao questionar que: "será que a crise sinaliza, por exemplo, o fim do neoliberalismo de livre mercado como modelo econômico dominante de desenvolvimento capitalista? A resposta depende do que entendemos com a palavra neoliberalismo. Minha opinião é que se refere a um projeto de classe que surgiu na crise dos anos 1970. Mascarado por muita retórica sobre liberdade individual, autonomia, responsabilidade pessoal e as virtudes da privatização, livre-mercado e livre-comércio, legitimou políticas draconianas destinadas a restaurar e consolidar o poder da classe capitalista. Esse projeto tem sido bem-sucedido, a julgar pela incrível centralização da riqueza e do poder observável em todos os países que tomaram o caminho neoliberal. E não há nenhuma evidencia de que ele está morto" (HARVEY, 2011, p. 16). 
retração na economia, privatiza-se a Saúde, restringe-se a Previdência Social e vincula a Assistência Social ao Trabalho ou implementam-se programas focalizados na pobreza extrema. Afinal, no modelo de governo que se instala no país, com uma inclinação de forte a interferências exteriores, em que se deve trabalhar mais e pensar menos, não seria a assistência social, como direito, que seria valorizada. 


\section{REFERÊNCIAS}

ABRAHAMSON, Peter. O retorno das medidas de ativação na política de bem-estar dinamarquesa: emprego e proteção social na Dinamarca. Rev. SER Social, Brasília, n. 25, p. 244-273, 2009.

O conceito de trabalho: A perspectiva histórico-ontológica. In: Curso Virtual A Precariedade do Trabalho no Capitalismo Global, 2012 Disponível em:

< http://www.telacritica.org/AULA\%201 A\%20categoria\%20trabalho.pdf> Acesso em: 15 de outrubro de 2016.

ANTUNES, Ricardo. A Dialética do Trabalho: escritos de Marx e Engels. Antunes, Ricardo (org.) São Paulo: Expressão Popular, 2004.

\& ALVES, Giovanni. AS MUTAÇÕES NO MUNDO DO TRABALHO NA ERA DA MUNDIALIZAÇÃO DO CAPITAL. In: rev. Educ. Soc. Campinas: vol. 25, n. 87, maio/ago., 2004 p. 335-351.

O caracol e sua concha: ensaios sobre a nova morfologia do trabalho. São Paulo: Boitempo, 2005.

Adeus ao trabalho? Ensaios sobre as metamorfoses e a centralidade do mundo do trabalho. 6. ed. São Paulo: Cortez; Campinas: Ed. UNICAMP, 2006.

ANTUNES, Ricardo. Trabalho uno ou omni: a dialética entre o trabalho concreto e o trabalho abstrato. Rev. Argumentum, Vitória, v. 2, n. 2, p. 09-15, jul./dez. 2010.

; DRUCK, Graça. A terceirização sem limites: a precarização do trabalho como regra. In: O Social em Questão - Ano XVIII - n 34, 2015.

ARRETCHE, Marta. T. S. O Sistema de Proteção Social Brasileiro: em direção a um modelo descentralizado. São Paulo: SEADE, 1997.

AZEVEDO, Celia M. M. de. ONDA NEGRA MEDO BRANCO: O negro no imaginário das elites do século XIX. Rio de Janeiro: Paz e Terra, 1987.

BARBALET, J. M. A cidadania. Lisboa: Editorial Estampa, 1989. 
BARBOSA, Lívia. Igualdade e meritocracia: a ética do desempenho nas sociedades modernas. 4aㅗ ed. Rio de Janeiro: Fundação Getúlio Vargas: Editora FGV, 2003.

BASBAUM, Leôncio. Sociologia do Materialismo: introdução à história da filosofia. São Paulo: Símbolo S.A Indústria Gráficas, 1978.

BEHRING, Elaine R. Crise do capital, fundo público e valor. In: BOSCHETTI, Ivanete et al. (orgs). Capitalismo em crise: Política social e Direitos. São Paulo: Cortez, 2010.

.; BOSCHETTI, Ivanete. Política social: fundamentos e história. São Paulo: Cortez, 2011.

BEVERIDGE. William. Las bases de la seguridad social. México: Fondo de Cultura Econômica, S. A. de C. V. 1987.

BOBBIO, Norberto. A era dos Direitos. Rio de Janeiro: Elsevier, trad. Carlos Nelson Coutinho, 2004.

BONAVIDES, Paulo. Do Estado Liberal ao Estado Social. São Paulo: Saraiva, 1961.

BOSCHETTI, Ivanete. As Forças de Apoio e Oposição à Primeira Proposta de Regulamentação da Assistência Social no Brasil. In: Cadernos do Universidade de Brasília - UnB: CEAM, NEPPOS, Conflitos de Interesses e a Regulamentação da Política de Assistência Social, 2002.

BOSCHETTI, Ivanete. Assistência Social no Brasil: um direito entre originalidade e conservadorismo. 2. ed. rev. ampl. Brasília: Gesst/SER/UnB, 2003.

Seguridade Social e Trabalho: paradoxos na construção das políticas de previdência e assistência social no Brasil. Brasília: Letras Livres: UnB, 2008.

Avaliação de políticas, programas e projetos sociais. In: CFESS/ABEPSS. Serviço Social: Direitos Sociais e Competências Profissionais. Brasília: CFESS, ABEPSS, 2009a, p. $575-593$. 
Seguridade social no Brasil: conquistas e limites à sua efetivação. In Serviço Social Direitos Sociais e Competências profissionais. Brasília CFESS/ABEPSS, 2009b.

América Latina, Política Social e Pobreza: "novo" modelo de desenvolvimento? In: SALVADOR, Evilásio, [et al.] (org.). Financeirização, fundo público e política social. São Paulo: Cortez, p. $31-58,2012$.

A Insidiosa Corrosão dos Sistemas de Proteção Social Europeus. Rev. Serviço Social \& Sociedade, São Paulo, n. 112, p. 754-803, out./dez. 2012.

. A Assistência no Capitalismo Contemporâneo e Tensões no Trabalho de Assistentes Sociais. VIII, Jornada internacional de políticas públicas, Maranhão 2015.

Assistência Social e Trabalho no Capitalismo. São Paulo: Cortez, 2016

BRASIL. PRESIDENCIA DA REPUBLICA. CASA CIVIL, Subchefia para Assuntos Jurídicos. CONSTITUIÇÃO DA REPUBLICA FEDERATIVA DO BRASIL DE 1988. Disponível em: http://www.planalto.gov.br/ccivil 03/constituicao/constituicao.htm Acesso em: 15 de novembro de 2016

BRASIL. SENADO FEDERAL. Lei de Diretrizes e Bases da Educação Nacional. Brasília, 2005. Disponível em: https://www2.senado.leg.br/bdsf/bitstream/handle/id/70320/65.pdf Acesso em 06 de Janeiro de 2017

BRASIL. Ministério do Desenvolvimento Social. Lei Orgânica da Assistência Social Anotada. Disponível em: http://www.mds.gov.br/webarquivos/publicacao/assistencia social/Normativas/LoasAnotada. pdf Acesso em: 06 de Janeiro de 2017

BRASIL. Ministério do Desenvolvimento Social e Combate à Fome. Orientações técnicas para o programa nacional de promoção do acesso ao mundo do trabalho - acessuas trabalho. Disponível em:

$<$ http://www.mds.gov.br/webarquivos/publicacao/brasil sem miseria/Acessuas.pdf $>$ Acesso em: 12 de novembro de 2016.

BRASIL. PRESIDENCIA DA REPUBLICA: CASA CIVIL - Subchefia para Assuntos Jurídicos. LEI No 10.836, DE 9 DE JANEIRO DE 2004. Cria o Programa Bolsa Família e dá outras 
providências. Disponível em: < http://www.planalto.gov.br/ccivil 03/ ato20042006/2004/lei//10.836.htm> Acesso em: 10 de novembro de 2016

. CAMARA DOS DEPUTADOS DO BRASIL. PROJETO DE LEI N. 6.021, DE 2009. Disponível em: http://www.camara.gov.br/sileg/integras/696640.pdf Acesso em 11 de novembro de 2016.

. CONSELHO NACIONAL DA ASSISTÊNCIA SOCIAL. RESOLUÇÃO № 33, DE 28

DE NOVEMBRO DE 2011. Define a Promoção da Integração ao Mercado de Trabalho no campo da assistência social e estabelece seus requisitos. Disponível em: <http://www.social.mg.gov.br/images/stories/subproeps/cnas\%202011\%20\%20033\%20\%2028.11.2011.pdf> 14 de novembro de 2016.

CONSELHO NACIONAL DA ASSISTÊNCIA SOCIAL. RESOLUÇÃO №- 18, DE 24 DE MAIO DE 2012. Institui o Programa Nacional de Promoção do Acesso ao Mundo do Trabalho ACESSUAS-TRABALHO. Disponível em: https://conferencianacional.files.wordpress.com/2013/12/cnas-2012-018-24-05-2012.pdf> Acesso em: 14 de novembro de 2016. CONSELHO NACIONAL DA ASSISTÊNCIA SOCIAL. RESOLUÇÃO № 109, DE 11 DE NOVEMBRO DE 2009 Aprova a Tipificação Nacional de Serviços Socioassistenciais. 2009.

. Ministério do Planejamento, Orçamento e Gestão. Plano Plurianual 2012-2015

atualizado. Brasília, $2011 . \quad$ Disponível em: http://www.planejamento.gov.br/assuntos/planejamento-e-investimentos/plano plurianual Acesso em: 12 de dezembro de 2015.

Ministério do Desenvolvimento Social e Combate à Fome. Perguntas Frequentes Bolsa Família. Disponível em: < http://mds.gov.br/acesso-a-informacao/perguntasfrequentes/bolsa-familia/beneficios/beneficiario/beneficio-de-superacao-da-extremapobreza> Acesso em: 20 de janeiro de 2016.

Ministério do Desenvolvimento Social e Combate à Fome. População negra é a maior beneficiária de programas sociais no Brasil. Disponível em: < http://mds.gov.br/area-de-imprensa/noticias/2013/dezembro/populacao-negra-e-a-maiorbeneficiaria-de-programas-sociais-no-brasil> Acesso em: 16 de novembro de 2015 
. Câmara dos Deputados do Brasil. Comissão condiciona Bolsa Família a inscrição em curso de qualificação profissional. 2016. Disponível em: < http://www2.camara.leg.br/camaranoticias/noticias/ASSISTENCIA-SOCIAL/503099COMISSAO-CONDICIONA-BOLSA-FAMILIA-A-INSCRICAO-EM-CURSO-DEQUALIFICACAO-PROFISSIONAL.html> Acesso em 06 de Janeiro de 2017.

MINISTÉRIO DO DESENVOLVIMENTO SOCIAL E COMBATE À FOME. Secretaria Nacional de Assistência Social, POLITICA NACIONAL DA ASSISTÊNCIA SOCIAL e NORMA OPERACIONAL BASICA DO SUAS. Brasília, 2005

MINISTÉRIO DO DESENVOLVIMENTO SOCIAL E COMBATE À FOME. Secretaria Nacional de Assistência Social, Orientações Técnicas: Centro de Referência Especializado de Assistência Social - CREAS, 2011.

MINISTÉRIO DO DESENVOLVIMENTO SOCIAL E COMBATE À FOME. Secretaria Nacional de Assistência Social, Orientações Técnicas: Centro de Referência de Assistência Social - CRAS, 2009.

MINISTÉRIO DO DESENVOLVIMENTO SOCIAL E COMBATE À FOME. Secretaria Nacional de Assistência Social, Orientações Técnicas sobre o PAIF, 2012.

Ministério do Desenvolvimento Social e Combate à Fome. Secretaria Nacional de Assistência Social, BOLSA FAMÍLIA TRANSFERÊNCIA DE RENDA E APOIO À FAMÍLIA NO ACESSO À SAÚDE, À EDUCAÇÃO E À ASSISTÊNCIA SOCIAL, 2015. Disponível em: $<$

http://www.mds.gov.br/webarquivos/publicacao/bolsa familia/Cartilhas/Cartilha PBF 2015.p df> Acesso em: 20 de setembro de 2016.

Ministério do Desenvolvimento Social e Agrário. Decisão do CNAS possibilita inclusão produtiva dos beneficiários do Bolsa Família. Disponível em: https://mds.gov.br/area-de-imprensa/noticias/2016/dezembro/decisao-do-cnas-possibilitainclusao-produtiva-dos-beneficiarios-do-bolsa-familia> 05 de Janeiro de 2017.

BRAVO, Maria Inês Souza. Gestão Democrática na Saúde: o potencial dos conselhos. In: Política Social e Democracia. BRAVO, Maria I. S. \& PEREIRA-PEREIRA, Potyara, A. (orgs.), 4. Ed, São Paulo: Cortez; Rio de Janeiro: UERJ, 2008. 
CARDOSO, Adalberto. Escravidão e Sociabilidade capitalista: Um ensaio sobre inercia social. rev. Novos Estudos, mar. 2008.

CHESNAIS, F. A mundialização do capital. São Paulo: Xam, 1996.

COUTINHO, Carlos Nelson. Contra corrente: ensaios sobre democracia e socialismo. São Paulo: Cortez, 2000.

DAL ROSSO, Sadi. Mais trabalho!: a intensificação do labor na sociedade contemporânea. São Paulo: Boitempo, 2008.

ENGELS, F. Sobre o papel do Trabalho na transformação do Macaco em Homem. In: Antunes, R (org.). A Dialética do Trabalho: escritos de Marx e Engels. São Paulo: Expressão Popular, 2004.

Sobre o papel do trabalho no Transformação do Macaco em Homem. 2005, disponível em: www.ebooksbrasil.org/adobeebook/macaco.pdf.

A situação da classe trabalhadora na Inglaterra. São Paulo: Boitempo, 2008.

FERNANDES, Florestan. A revolução Burguesa no Brasil: ensaio de interpretação sociológica. 5. ed. São Paulo: Globo, 2006.

A integração do negro na sociedade de classes. 5ํㅗ ed. São Paulo: Globo, 2008.

GIL, Antônio Carlos. Métodos e Técnicas de Pesquisa Social. 4 ed. São Paulo: Editora Atlas S. A., 1995.

GUIRALDELLI, Reginaldo. Mulheres que tecem a vida: trabalho e gênero em tempos precarizados. Tese defendida no Programa de Pós-Graduação em Serviço Social na Universidade Estadual Paulista Júlio Mesquita Filho - UNESP, 2010.

HARVEY, David. O enigma do Capital: e as crises do capitalismo. São Paulo: Boitempo, 2011. 
HAYEK, Friedrich von. Direito, legislação e liberdade: uma nova formulação dos princípios liberais de justiça e economia política. A miragem da justiça social. São Paulo: Visão, 1985.v. II

O Caminho da Servidão. Rio de Janeiro: Biblioteca do Exército, 1994.

HIGGINS, Joan. States of welfare: a comparative analysis of social policy. New York: St. Martin's Press, Inc., 1983.

HOLANDA, Sergio Buarque de. Raízes do Brasil. São Paulo: Companhia das Letras, 26aㅡ ed., 1995.

IAMAMOTO, Marilda Vilela. Serviço Social em tempo de capital fetiche: capital financeiro, trabalho e questão social. São Paulo: Cortez, 2007.

IANNI, Octavio. A sociologia de Florestan Fernandes. In: rev. Estudos Avançados, 1996.

A CONSTRUÇÃO DA CATEGORIA. In: rev. HISTEDBR On-line, Campinas, n. especial, abr. 2011, p. 397-416.

JESSOP, Bob. Política Social, Estado e "Sociedade". In: rev. Ser Social, Brasília, v. 15, n. 33, jul./dez., 2013, p. 261-384.

KONDER, Leandro. O que é Dialética. São Paulo: Editora Brasiliense, coleção primeiros passos, 25ำed. 1981.

LAFARGUE, Paul. Direito à Preguiça. 2005, disponível em: www.eBooksBrasil. Com.

LENIN, V. O Imperialismo: fase superior do capitalismo. São Paulo: Global, 1979.

LESSA, Simone E. do C. A formação via PNQ e inserção produtiva dos CRAS: a reposição empobrecida e emergencial da qualificação de trabalhadores In: Serviço Social e Sociedade, São Paulo: n. 106, abr./jun., 2011 p. 284-313.

LUCÁKS, Gyorgy. L’uomo e la democrazia. Roma: Lucarini, 1987.

LYRA FILHO, Roberto. O que é Direito? São Paulo: editora Brasiliense, 11 ${ }^{\text {a }}$ ed. 1982. 
MARX, Karl. O Capital, livro 1, capítulo VI (inédito). São Paulo: Livraria Editora Ciências Humanas, 1978, p. 70-80.

O capital: Crítica da economia política (Vol.I), Tomo I - 2ªed. São Paulo: Ed. Nova cultural, 1985.

. Trabalho alienado e superação positivada autoalienação humana. In: FERNANDES, Florestan (Org.). Marx, Engels. História. São Paulo: Ática, 1989. (Coleção Grandes Cientistas Sociais, n. 36).

O Capital. In: Os Economistas, livro primeiro, Tomo II, São Paulo: Nova Cultural, 1996.

. Manuscritos econômico-filosóficos. São Paulo: Boitempo, 2004.

Crítica do Programa de Gotha. São Paulo: Boitempo, 2012.

Processo de Trabalho e Processo de Valorização. In: Antunes, R (org.). A Dialética do Trabalho: escritos de Marx e Engels. São Paulo: Expressão Popular, 2013.

MANDEL, Ernest. Teoria Marxista do Estado. ed: Antidoto, 1977.

MASCARO, Alysson Leandro. Introdução à Filosofia do Direito: Dos Modernos aos Contemporâneos. São Paulo: Atlas, 2002.

MAZZEO, Antonio Carlos. Estado e Burguesia no Brasil: origens da autocracia burguesa. São Paulo: Boitempo, 2015.

MINAYO, Maria Cecília de Souza (org.). Pesquisa Social. Teoria, método e criatividade. 18 ed. Petrópolis: Vozes, 2001.

NETTO, José Paulo. Relendo a Teoria Marxista da História. In: Sanfelice, J. L ; Lombardi, C; Saviani, D. (Orgs.) História e Historiografia da Educação. Campinas, SP: Autores Associados: HISTEDBR, 1998. (Coleção Educação Contemporânea).

Introdução ao estudo do método de Marx. São Paulo: Expressão popular, 2011. 
OLIVEIRA, Heloisa Maria José de. Cultura política e assistência social: uma análise das orientações dos gestores estaduais. São Pulo: Cortez, 2003.

PACHUKANIS, E. B. TEORIA GERAL DO DIREITO E MARXISMO. São Paulo: editora Acadêmica, 1988.

PAULA, Renato F. dos S. Serviço Social, Estado e Desenvolvimento Capitalista: (im) possibilidades neodesenvolvimentistas e projeto profissional. Tese defendida no Programa de Estudos Pós-Graduados em Serviço Social da Pontifícia Universidade Católica de São Paulo, 2013.

PEREIRA, Camila Potyara. Proteção social no capitalismo: contribuições à crítica de matrizes teóricas e ideológicas conflitantes. Tese de doutorado, apresentada ao Programa de Pós-Graduação em Política Social, do Departamento de Serviço Social da Universidade de Brasília, 2013.

PEREIRA-PEREIRA, Potyara A.. A assistência social na perspectiva dos direitos: crítica aos padrões dominantes de proteção aos pobres no Brasil. Brasília: Thesaurus, 1996.

Estado, regulação social e controle democrático. In: BRAVO, Maria Inês Souza; PEREIRA, P. A.P. (Orgs). Política Social e Democracia. 2 ed. São Paulo: Cortez; Rio de Janeiro: UERJ, 2002.

Política de Assistência Social no Brasil: Avanços e Retrocessos. In: Cadernos do Universidade de Brasília - UnB: CEAM, NEPPOS, Conflitos de Interesses e a Regulamentação da Política de Assistência Social, 2002.

Necessidades Humanas: Subsídios à crítica dos mínimos sociais. São Paulo: Cortez, 2006.

. Estado, Regulação Social e Controle Democratico. In: Política Social e Democracia. BRAVO, Maria I. S. \& PEREIRA-PEREIRA, Potyara, A. (orgs.), 4. Ed, São Paulo: Cortez; Rio de Janeiro: UERJ, 2008. 
Do Estado social ao Estado anti-social. In: PEREIRA-PEREIRA, Potyara A. et al. (orgs). Política Social, Trabalho e Democracia em questão. Brasília: Universidade de Brasília - UnB, PPGPS, 2009.

Política Social: temas e questões. São Paulo: Cortez, 2011.

Proteção social contemporânea: cui prodest? In: Rev. Serviço Social \& Sociedade, São Paulo, n. 116, p. 636-651, out./dez. 2013.

\& SIQUEIRA, Marcos Cesar A. Política social e Direitos Humanos sob o jugo imperial dos Estados Unidos. In: Rev. Serviço Social \& Sociedade, São Paulo, n. 119, p. 446-467, jul/set. 2014.

Degradação do trabalho e políticas sociais "ativas" na ordem neoliberal: aproximações ao caso brasileiro. In: rev. Ser Social. Brasília, v. 17, n. 37, jul. /dez. 2015 p. 455-480.

PIERSON, C. Beyond the Welfare State? Cambridge. Polity Press. 1991, pp. 102 a 140. Resumo preparado por Potyara A. P. Pereira, a partir da tradução do texto original.

POLANYI, Karl. A Grande transformação: as origens de nossa época. $2^{\mathfrak{a}}$ edição. Rio de Janeiro: Campus, 2000.

POULANTZAS, Nicos. Sobre el Estado Capitalista. Barcelona, Laia, 1974.

O Estado em crise. Rio de Janeiro: Graal, 1977.

PODER POLITICO Y CLASSES SOCIALES EN EL ESTADO CAPITALISTA. Madrid - Espanha: ed. Siglo Veintiuno, 2007.

PRADO JR. Caio. HISTORIA ECONOMICA DO BRASIL. São Paulo: editora Brasiliense, 26ํㅜ ed., 2012.

QUIVY, Raymond; CAMPENHOUDT, Luc Van. Manual de investigação em Ciências sociais. (2‥ Ed.). Lisboa: Gradiva, 1998.

RUBIN, Isaak Illich. A TEORIA MARXISTA DO VALOR. São Paulo: Polis, 1987. 
SALVADOR, Evilasio; TEIXEIRA, Sandra. Orçamento e Políticas sociais: metodologia de análise na perspectiva crítica. Revista de Políticas Públicas (UFMA), v. 18, p. 15-32, 2014.

SILVA, Maria Lucia L. da. (Des) estruturação do trabalho e condições para a universalização da Previdência Social no Brasil. Tese defendida no Programa de PósGraduação em Política Social na Universidade de Brasília - UnB, 2011.

SILVA, Maria Ozanira da Silva e; Yazbeck, Maria Carmelita; GIOVANNI, Geraldo Di. A política social brasileira no século XXI: a prevalência dos programas de transferência de renda. São Paulo: Cortez, 2008.

; YASBEK, Maria C. Política de trabalho e renda no Brasil contemporâneo. São Paulo: Cortez, 2006.

SILVEIRA, Antônio M. da. Erradicação da Miséria - o pacto básico. In: SUPLICY, Eduardo Matarazzo. Programa de Garantia de Renda Mínima. Brasília: Senado Federal, 1992.

SIMOES, Carlos. Curso de Direito do Serviço Social. São Paulo: Cortez, 4ํa ed. 2010.

TEORIA \& CRITICA DOS DIREITOS SOCIAIS: O Estado Social e o Estado Democrático de Direito. São Paulo: Cortez, 2013.

SPOSATI. Aldaíza de Oliveira. et al. (orgs) Assistência na trajetória das políticas sociais brasileiras: uma questão em análise, 7.ed. São Paulo: Cortez, 1998.

A menina LOAS: um processo de construção da Assistência Social ( $3^{\underline{a}}$ ed.). São Paulo: Cortez, 2007.

STEIN, Rosa H. A (NOVA) QUESTÃO SOCIAL E AS ESTRATÉGIAS PARA SEU ENFRENTAMENTO. Rev. SER Social, Brasília, n. 6, p. 133 -168, 2000.

TRINDADE, José D. de L. Representações de trabalhadores, gatos, e empregadores sobre o trabalho escravo. In: OLHARES SOBRE A ESCRAVIDÃO CONTEMPORÂNEA: NOVAS CONTRIBUIÇÕES CRÍTICAS. FIGUEIRA, Ricardo Rezende; PRADO, Adonia Antunes (orgs). Cuiabá: EDUFMT, 2011 
TSÉ-TUNG, Mao. SOBRE A PRATICA \& SOBRE A CONTRADIÇÃO. São Paulo: Expressão Popular, 1999.

WACQUANT, Loic. As Prisões da Miséria. Rio de Janeiro: Jorge Zahar Ed., 2001.

WEBER, Max. A ética protestante e o espirito do capitalismo. São Paulo: Martim Claret, 2013.

WOOD, Ellen M. Democracia contra Capitalismo: a renovação do materialismo histórico. São Paulo: Boitempo, 2006.

YAZBEK, Maria Carmelita. A Política Social brasileira nos anos 90: refilantropização da Questão Social. In Cadernos ABONG no 11, 1995.

. Pobreza no Brasil contemporâneo e formas de seu enfrentamento. In: Serviço Social e Sociedade, São Paulo, n. 110, p. 288-322, abr./jun. 2012. 
ANEXOS 


\section{ANEXO A}

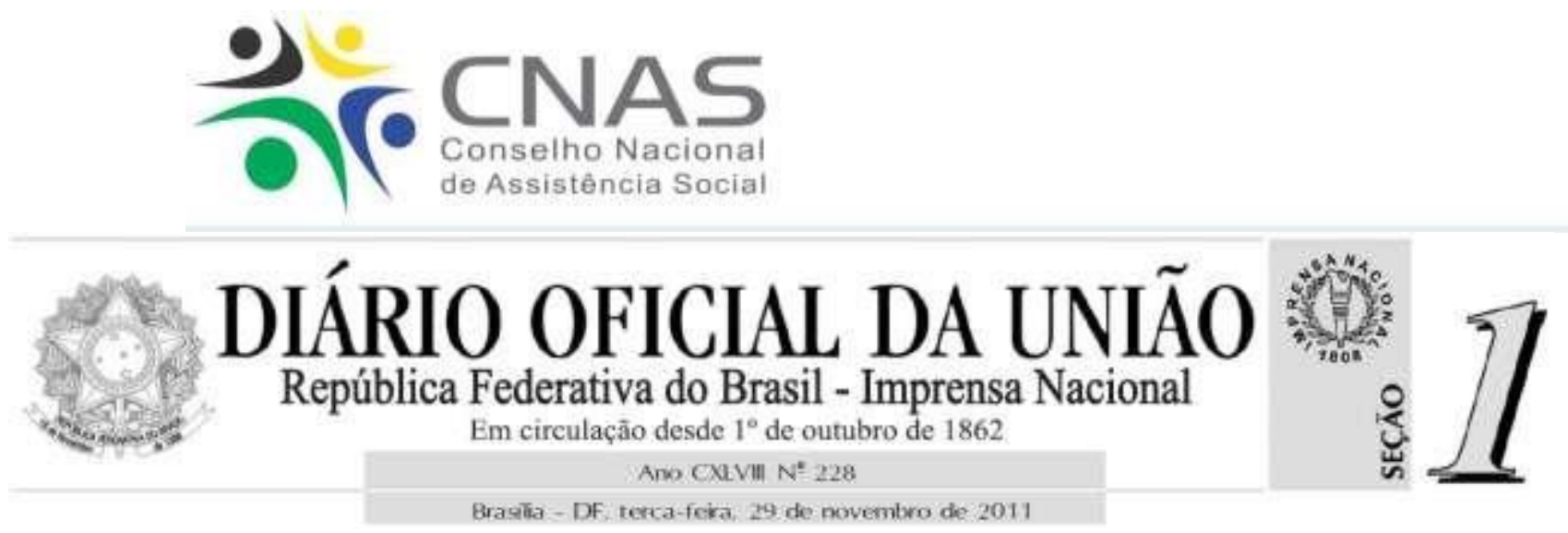

\section{RESOLUÇÃO № 33, DE 28 DE NOVEMBRO DE 2011.}

Define a Promoção da Integração ao Mercado de Trabalho no campo da assistência social e estabelece seus requisitos.

O CONSELHO NACIONAL DE ASSISTÊNCIA SOCIAL (CNAS), em reunião ordinária realizada nos dias 23 e 24 de novembro de 2011, no uso da competência que lhe conferem os incisos II, V, IX e XIV do artigo18 da Lei n. 8.742, de 7 de dezembro de 1993 - Lei Orgânica da Assistência Social (LOAS);

Considerando a Lei Orgânica da Assistência Social - Lei no 8.742 de 7 de dezembro de 1993, com última alteração dada pela Lei no 12.435/2011, que em seu artigo 2으, inciso I, alínea c, estabelece a Integração ao Mercado de Trabalho como um dos objetivos da assistência social;

Considerando a Resolução CNAS no 145, de 15 de outubro de 2004, que aprova a Política Nacional de Assistência Social - PNAS;

Considerando a Resolução CNAS no 130, de 15 de julho de 2005, que aprova a Norma Operacional Básica do Sistema Único de Assistência Social - NOB/SUAS;

Considerando a Resolução CNAS no 269, de 13 de novembro de 2006 que aprova a Norma Operacional Básica de Recursos Humanos do SUAS - NOB-RH/SUAS;

Considerando a Resolução CNAS no 109, de 11 de novembro de 2009, que aprova a Tipificação Nacional dos Serviços Socioassistenciais;

Considerando a Resolução CNAS no 16, de 5 de maio de 2010, que define os parâmetros nacionais para a inscrição das entidades e organizações de assistência social, bem como dos serviços, programas, projetos e benefícios socioassistenciais nos Conselhos de Assistência Social dos Municípios e do Distrito Federal; 


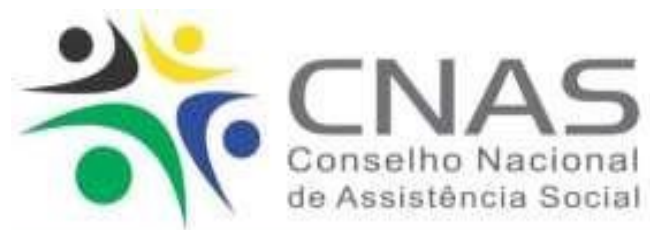

Considerando a Resolução CNAS no 27 de 19 de setembro de 2011, que caracteriza as ações de assessoramento, defesa e garantia de direitos no âmbito da assistência social; Considerando o Decálogo dos Direitos Socioassistenciais e os Compromissos Éticos

Socioassistenciais como documentos orientadores da Política de Assistência Social, aprovados na V Conferência Nacional de Assistência Social;

Considerando que a função primeira da assistência social é a proteção social e que a integração ao "mundo do trabalho" não é de responsabilidade exclusiva da assistência social, mas resultado da ação intersetorial de diversas políticas públicas.

Considerando que a assistência social tensiona a demanda para a oferta de determinados serviços, inclusive os do sistema de trabalho, emprego e renda.

Considerando que o trabalho sem proteção social é uma violação aos direitos;

Considerando que o trabalho é estruturador de identidades, promove a sociabilidade e possibilita o pertencimento social, constituindo o sujeito em sua totalidade;

Considerando que a assistência social identifica e recepciona as demandas, é mobilizadora, garantidora de direitos e vocalizadora da população em vulnerabilidade;

Considerando que a assistência social reconhece as capacidades e potencialidades dos usuários, promove o seu protagonismo na busca de direitos e espaços de integração relacionados ao mundo do trabalho, bem como o resgate de sua auto-estima, autonomia e resiliência;

Considerando que os indivíduos e famílias devem ser atendidos no conjunto de suas vulnerabilidades, identificadas a partir do processo de integração ao mundo do trabalho;

Considerando as contribuições dos especialistas e das entidades envolvidas com a temáticanas reuniões do Grupo de Trabalho do CNAS;

\section{RESOLVE:}

Art. 1․ Para efeito desta resolução fica estabelecido que a promoção da integração ao mercado de trabalho no campo da assistência social deve ser entendida como integração ao "mundo do trabalho", sendo este um conceito mais amplo e adequado aos desafios da política de assistência social;

Art. 20. Definir que a Promoção da Integração ao Mundo do Trabalho se dá por meio de um "conjunto integrado de ações das diversas políticas cabendo à assistência social ofertar ações de proteção social que viabilizem a promoção do protagonismo, a participação 


\section{そั0 CNAS}

cidadã, a mediação do acesso ao mundo do trabalho e a mobilização social para a construção de estratégias coletivas".

Art.3․ Estabelecer como requisitos básicos para as ações de promoção da integração ao mundo do trabalho no âmbito da assistência social:

I.

Referenciamento na rede socioassistencial, conforme organização do

Sistema Único de Assistência Social - SUAS;

II.

Articulação com as demais políticas públicas implicadas na integração ao mundo do trabalho;

III.

Atuação em grupos com foco no fortalecimento de vínculos e desenvolvimento de atitudes e habilidades para a inserção no mundo do trabalho com monitoramento durante este processo;

IV.

Promoção da formação político-cidadã, desenvolvendo e/ou resgatando e/ou fortalecendo o protagonismo através da reflexão crítica permanente como condição de crescimento pessoal e construção da autonomia, para o convívio social;

V.

Garantia da acessibilidade e tecnologias assistivas para a pessoa com deficiência ou com mobilidade reduzida, viabilizando a condição de seu alcance para utilização com segurança e autonomia dos espaços, mobiliários, tecnologias, sistemas e meios de comunicação, conforme o conceito do desenho universal e as normas da ABNT;

VI.

Promoção dos apoios necessários às pessoas com deficiência e suas famílias para o reconhecimento e fortalecimento de suas potencialidades e habilidades à integração ao mundo do trabalho;

VII. Execução de programas e projetos que qualifiquem os serviços e benefícios socioassistenciais;

VIII.

Articulação dos benefícios e serviços socioassistenciais na promoção da integração ao mundo do trabalho.

Art. 4․ Esta resolução entra em vigor na data de sua publicação.

Carlos Eduardo Ferrari

Presidente do CNAS 


\section{ANEXO B}

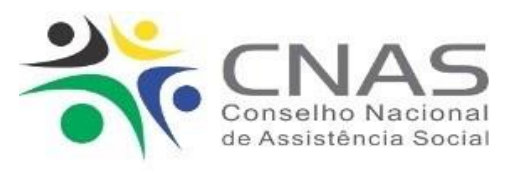

\section{Resolução}

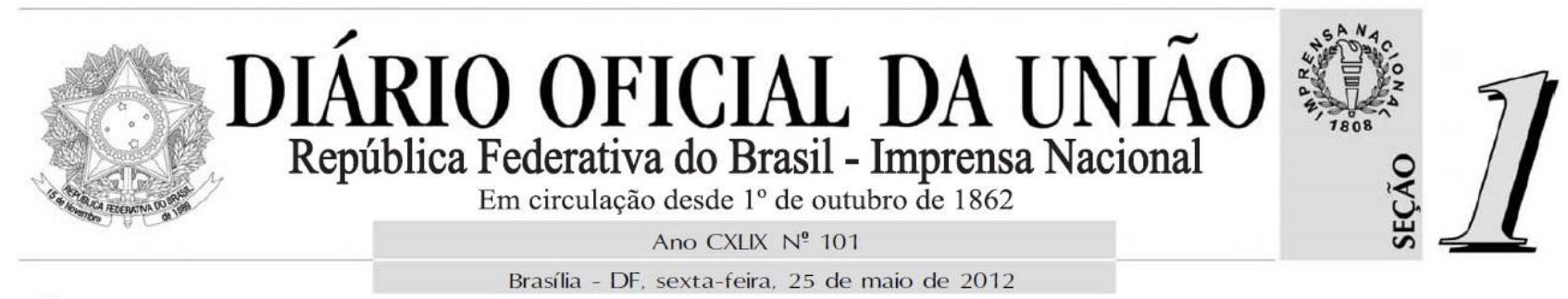

62

ISSN 1677-7042

Diário Oficial da União - Seção 1

$\mathrm{N}^{0} 101$, sexta-feira, 25 de maio de 2012

Ministério do Desenvolvimento Social e Combate à Fome

Conselho Nacional de Assistência Social

\section{RESOLUÇÃO CNAS № 18, DE 24 DE MAIO DE 2012.}

Institui o Programa Nacional de Promoção do Acesso ao Mundo do Trabalho - ACESSUAS-TRABALHO.

Alterada pela Resolução CNAS no 27/2014.

O CONSELHO NACIONAL DE ASSISTÊNCIA SOCIAL - CNAS, em reunião ordinária realizada nos dias $15,16,17$ e 18 de maio de 2012, no uso da competência conferida pelo art. 18 da Lei no

8.742, de 7 de dezembro de 1993 - Lei Orgânica da Assistência Social - LOAS,

Considerando a Resolução CNAS no 145, de 15 de outubro de 2004, que aprova a Política Nacional de Assistência Social;

Considerando a Resolução CNAS no 130, de 15 de julho de 2005, que aprova a Norma Operacional Básica do Sistema Único da Assistência Social - NOB/SUAS;

Considerando a Resolução CNAS no 109, de 11 de novembro de 2009, que dispõe sobre a Tipificação Nacional de Serviços Socioassistenciais;

Considerando a Lei no 8.742, de 07 de dezembro de 1993, que dispõe sobre organização da Assistência Social e demais alterações;

Considerando a Lei no 7.853, de 24 de outubro de 1989, que dispõe sobre o apoio às pessoas com deficiência, sua integração social, e dá outras providências;

Considerando o Decreto no 6.949, de 25 de agosto de 2009, que promulga a Convenção Internacional sobre os Direitos das Pessoas com Deficiência, assinados em Nova York, em 30 de março de 2007; 


\section{Resolução}

Considerando a Resolução CNAS no 33, de 28 de novembro de 2011, que define a Promoção da Integração ao Mercado de Trabalho no campo da Assistência Social e estabelece seus requisitos;

Considerando a Resolução CNAS no 34, de 28 de novembro de 2011, que define a habilitação e reabilitação da pessoa com deficiência e a promoção de sua integração à vida comunitária no campo da assistência social e estabelece seus requisitos;

Considerando a Lei no 12.513, de 26 de novembro de 2011, que institui o Programa Nacional de Acesso ao Ensino Técnico e Emprego - Pronatec;

\section{RESOLVE:}

Art. 10 Instituir o Programa Nacional de Promoção do Acesso ao Mundo do Trabalho - ACESSUASTRABALHO, na forma do Anexo.

$\S 1$ ㅇ O programa terá a vigência de 4 (quatro) anos, no período de 2015 a 2018.

§ 2 No término do prazo estabelecido no parágrafo anterior, não havendo deliberação em contrário do CNAS, o Programa será prorrogado por igual período.

$\S$ 3으 Anualmente será pactuado na Comissão Intergestores Tripartite - CIT e aprovados no CNAS as metas e os critérios de partilha desse Programa, conforme disponibilidade orçamentária do Ministério do Desenvolvimento Social e Combate à Fome.

Art. 20 Esse Programa ficará sob a responsabilidade do órgão Gestor da Assistência Social, e suas ações poderão ser executadas de forma direta ou em parceria com entidades e organizações de assistência social.

Art. 3ํ Esta Resolução entra em vigor na data de sua publicação.

Carlos Eduardo Ferrari

Presidente do CNAS 


\section{ANEXO B}

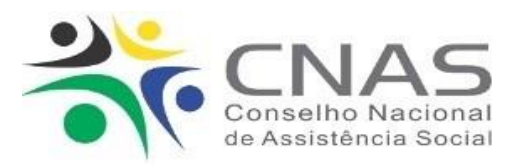

Resolução

\section{ANEXO DA \\ RESOLUÇÃO № 18, DE 24 DE MAIO DE 2012. \\ Programa Nacional de Promoção do Acesso ao Mundo do Trabalho - ACESSUAS-TRABALHO}

\section{Contextualização}

Nos últimos anos, o governo brasileiro vem desenvolvendo estratégias de inclusão social dos mais pobres, transferindo renda e expandindo serviços e benefícios socioassistenciais. Mesmo com esse esforço, 16 milhões de pessoas ainda permanecem na pobreza extrema e não conseguem acessar às políticas sociais, tais como: saúde, educação, habitação, assistência social, trabalho entre outros.

O Plano Brasil Sem Miséria foi criado pelo governo federal, visando romper barreiras que excluem e segregam essas famílias e indivíduos. Esse plano tem como principal estratégia articular transferência de renda, acesso a serviços e inclusão produtiva, com um conjunto de ações que envolvem a criação de novos programas e a ampliação de iniciativas já existentes, em parceria com estados, municípios e Distrito Federal, empresas públicas e privadas e organizações da sociedade civil. Para isso, o plano prevê o aumento e o aprimoramento dos serviços ofertados aliados à sensibilização e mobilização, para a geração de ocupação e renda e a melhoria da qualidade de vida.

Outra iniciativa do governo federal importante de ser mencionada é o Plano Nacional dos Direitos da Pessoa com Deficiência - Viver Sem Limite, que prevê ações de acesso à educação, saúde, inclusão social e acessibilidade. Uma das metas deste Plano é a efetivação do Programa BPC Trabalho, instituído por iniciativa do MDS, em parceria com o MEC, MTE e SDH/PR, que tem como objetivo promover o acesso das pessoas com deficiência, beneficiárias do BPC, à qualificação profissional e ao trabalho, com vistas à superação de barreiras, ao fortalecimento da autonomia, do protagonismo e da participação social.

Conforme a Lei no 8.742, de 7 de dezembro de 1993, Lei Orgânica da Assistência Social, a assistência social é política pública, direito do cidadão e dever do Estado. Constitui-se como política de seguridade social não contributiva, realizada por meio de um conjunto integrado de ações com intuito de garantir o atendimento das necessidades básicas. Ocupa-se de prover proteção à vida, reduzir danos, acompanhar populações em risco e prevenir a incidência de agravos à vida em face das situações de vulnerabilidade.

Cabe à assistência social identificar e acolher as demandas, mobilizar e garantir direitos e ser vocalizadora da população em vulnerabilidade, pois ela reconhece as capacidades e potencialidades dos usuários, promove o seu protagonismo na busca de direitos e espaços de integração relacionados ao mundo do trabalho, bem como o resgate de sua autoestima, autonomia e resiliência. 


\section{Resolução}

A LOAS, em seu Art. 24, qualifica a função dos programas na política de assistência social dispondo que, 'os programas de assistência social compreendem ações integradas e complementares com objetivos, tempo e área de abrangência definidos para qualificar, incentivar e melhorar os benefícios e serviços assistenciais".

Também em seu artigo 2을 inciso I, alínea c, prevê como um dos objetivos da Assistência Social a promoção da integração ao mercado de trabalho.

O Conselho Nacional de Assistência Social estabeleceu na Resolução CNAS no 33/2011, que a promoção da integração ao "mercado de trabalho", no campo da assistência social, deve ser entendida como integração ao "mundo do trabalho", por ser esse um conceito mais amplo e adequado aos desafios da política de assistência social. E, por isso, os indivíduos e famílias devem ser atendidos no conjunto de suas vulnerabilidades.

Assim, a integração ao "mundo do trabalho" não é de responsabilidade exclusiva da política de assistência social, mas resultado da ação intersetorial de diversas políticas públicas. O eixo de inclusão produtiva urbana do Plano Brasil sem Miséria articula ações e programas que favorecem a inserção ao mercado de trabalho por meio do emprego formal, do empreendedorismo individual e da economia solidária. Reúne iniciativas de oferta de qualificação profissional e intermediação de mão-de-obra, que visam à colocação dos usuários em postos de emprego com carteira de trabalho e previdência; de apoio a microempreendedores individuais, por meio de formalização, assistência técnica e acesso ao microcrédito produtivo orientado; e de fomento a cooperativas, autogestão e empreendimentos solidários.

De acordo com o art. 20 da Resolução CNAS no 33/2011, a Promoção da Integração ao Mundo do Trabalho dar-se-á por meio de um "conjunto integrado de ações das diversas políticas, cabendo à assistência social ofertar ações de proteção social, que viabilizem a promoção do protagonismo, a participação cidadã, a mediação do acesso ao mundo do trabalho e a mobilização social para a construção de estratégias coletivas".

Este Programa busca a autonomia das famílias usuárias da Política de Assistência Social, por meio do incentivo e da mobilização à integração ao mundo do trabalho. Possui, ainda, estreita articulação com o Plano Brasil Sem Miséria, com a promoção de estratégias, ações e medidas de enfrentamento à pobreza, por meio de mobilização de usuários; monitoramento da execução das ações do Programa e articulação com diferentes parceiros e políticas públicas.

\section{Objetivo}

Promover a integração dos usuários da assistência social ao mundo do trabalho, por meio de ações articuladas e mobilização social. 


\section{ANEXO B}

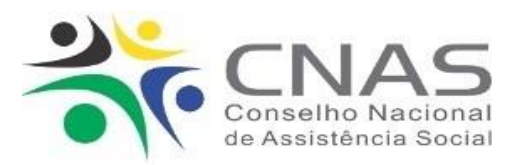

Resolução

\section{Descrição}

O Programa Nacional de Promoção do Acesso ao Mundo do Trabalho - ACESSUASTRABALHO, proposto, estabelece, conforme a Resolução CNAS no 33/2011, que a promoção da integração ao mundo do trabalho dar-se-á por meio da integração de ações das diversas políticas públicas, cabendo a Assistência Social viabilizar a promoção do protagonismo, a participação cidadã e a mediação do acesso ao mundo do trabalho.

A assistência social, a partir do seu reconhecimento enquanto política pública de proteção social, oferta serviços, programas, projetos e benefícios de caráter preventivo com intuito de desenvolver ações para que o risco não ocorra, bem como de reposição de direitos violados, na perspectiva de sua garantia. Nesse sentido a proteção social, principal objetivo dessa política, concretiza ações para produção de aquisições materiais e sociais, convivência social, protagonismo e fortalecimento de vínculos e da autonomia, garantia de direitos e condições dignas de vida. Ressalta-se que a assistência social realiza articulações entre diversas políticas públicas para garantir o atendimento integral na superação das vulnerabilidades apresentadas pelos usuários. Portanto, promover o acesso ao mundo do trabalho não é de responsabilidade exclusiva da política de assistência social, mas sim o resultado de uma ação intersetorial.

Nessa direção a Política é capaz de reconhecer a heterogeneidade dos espaços em que a população vive, permitindo a identificação das efetivas condições de vida das famílias. Dessa forma, ela proporciona a participação cidadã nos territórios, acolhendo e vocalizando as necessidades e reconhecendo as potencialidades dos usuários.

O Programa propõe o desenvolvimento de ações de articulação, mobilização e encaminhamento de pessoas em situação de vulnerabilidade e, ou risco social para garantia do direito de cidadania a inclusão ao mundo do trabalho, por meio, do acesso a cursos de qualificação e formação profissional, ações de inclusão produtiva e serviços de intermediação de mão de obra. Incluem ainda, ações de articulação com outras políticas públicas para superação das vulnerabilidades sociais.

As ações fomentam atividades de caráter informativo ou de orientação social que movimentem e circulem informações a respeito das ofertas e possibilidades de qualificação e formação profissional, de inclusão produtiva, com intuito de expandir o acesso a direitos, promover a autonomia e a melhoria da qualidade de vida da população beneficiada.

A implantação do Programa deve ser planejada e organizada de forma a identificar os processos que podem ser utilizados na mobilização, encaminhamento e acompanhamento dos usuários, como: conhecimento do território; identificação do perfil do público; implantação das condições 


\section{Resolução}

físicas e materiais necessárias à execução do programa; mapeamento das ofertas e oportunidades para inserção ao mundo do trabalho.

\section{Período de Vigência do-Programa:}

De 2012 até 2014, com pactuação deliberação de metas anuais. (Revogado pelo art. 3ㅇda Resolução CNAS no 27, de 14 de outubro de 2014, publicada no DOU em 15/10/2014, Seção I, Página 76).

\section{Usuários}

Populações urbanas e rurais em situação de vulnerabilidade e risco social com idade entre 16 e 59 anos, com prioridade para usuários de serviços, projetos, programas de transferência de renda e benefícios socioassistenciais, em especial para:

- Famílias e indivíduos com perfil do Plano Brasil Sem Miséria;

- Pessoas com deficiência beneficiárias do BPC;

- Jovens egressos do serviço de convivência para jovens;

- Pessoas inscritas no CADÚNICO;

- Egressos do sistema socioeducativo;

- Famílias com presença de situação de trabalho infantil;

- População em Situação de Rua;

- Famílias com crianças em situação de acolhimento provisório;

- Adolescentes e jovens egressos do serviço de acolhimento;

- Indivíduos e famílias moradoras em territórios de risco em decorrência do tráfico de drogas;

- Indivíduos egressos do sistema penal;

- Beneficiários do Programa Bolsa Família;

- Pessoas retiradas do trabalho escravo;

- Mulheres vítimas de violência;

- entre outros, para atender especificidades territoriais.

A mobilização e encaminhamento de Adolescentes de 16 a 17 anos para cursos de capacitação profissional estará condicionada ao disposto no Decreto na 6.484/2008 (lista TIP - regulamenta os artigos 3oa alínea "d", e 4을 da Convenção 182 da Organização Internacional do Trabalho (OIT) que trata da proibição das piores formas de trabalho infantil e ação imediata para sua eliminação, aprovada pelo Decreto Legislativo no 178, de 14 de dezembro de 1999, e promulgada pelo Decreto no 3.597, de 12 de setembro de 2000, e dá outras providências ) que regulamenta as atividades consideradas impróprias para esta faixa etária.

\section{Condições de Acesso}

Residentes no município e no Distrito Federal

\section{Abrangência}




\section{ANEXO B}

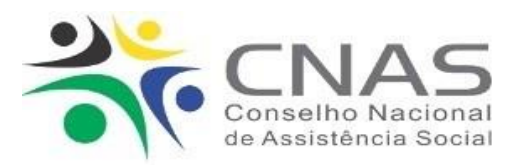

Resolução

Municipal e Distrito Federal

\section{Ações do Programa}

- Articular com outras políticas públicas, que visem à melhoria da qualidade de vida e superação das vulnerabilidades sociais;

- Articular com as demais políticas implicadas na integração ao mundo do trabalho, desenvolvendo ações intersetoriais;

- Articular parcerias com órgãos e entidades governamentais e não governamentais, que ofertam ações de formação e qualificação profissional, inclusão produtiva e intermediação de mão de obra;

- Articular com órgãos e entidades governamentais e não governamentais que atuam no apoio da pessoa com deficiência para o acesso à formação e qualificação profissional, inclusão produtiva e intermediação de mão de obra.

- Identificação e busca ativa do público prioritário;

- Mobilização e sensibilização das famílias sobre as oportunidades de acesso e de participação em cursos de formação e qualificação profissional, programas e projetos de inclusão produtiva e serviços de intermediação de mão de obra;

- Divulgação do Programa, por meio de reuniões com a comunidade, palestras, oficinas, campanhas de mídia, entre outros;

- Orientação às pessoas com deficiência e suas famílias quanto às oportunidades de acesso e de participação em cursos de formação e qualificação profissional, programas e projetos de inclusão produtiva e serviços de intermediação de mão de obra, por meio de visitas domiciliares;

- Formação planejada voltada à pessoa com deficiência, com vistas a vivenciar aspectos inerentes ao mundo do trabalho.

- Para cadastramento do usuário no Cadúnico;

- Para outras políticas públicas visando à superação das dificuldades que os impossibilitem o acesso ao mundo do trabalho, em especial as pessoas com deficiência;

- Para preenchimento das vagas ofertadas de cursos de formação e qualificação profissional;

- Para órgãos de intermediação de mão-de-obra e demais instituições que promovam ações de inclusão produtiva. 


\section{Resolução}

- Acesso aos cursos de formação e qualificação profissional, bem como, aos programas e projetos de inclusão produtiva e serviços de intermediação de mão de obra;

- Apoio à inclusão em serviços, programas, projetos e benefícios socioassistenciais e de transferência de renda, nos casos em que se fizer necessário, aos usuários participantes dos cursos ofertados, e suas famílias;

- Realização de ações conjuntas entre as equipes do Programa e dos órgãos e entidades governamentais e não governamentais, que ofertam formação e qualificação profissional, programas e projetos de inclusão produtiva, e dos serviços de intermediação de mão de obra, entre outros;

- Incluir em Acompanhamento Familiar do SUAS as famílias das pessoas com deficiência encaminhadas para as vagas ofertadas;

- Realização de ações de sensibilização junto às instituições ofertantes sobre as barreiras atitudinais;

- Identificação das barreiras que impedem o usuário ao acesso e desenvolvimento de estratégias para superá-las, em parceria com outras políticas.

\section{Critérios para adesão ao Programa}

Pactuados anualmente pela Comissão Intergestores Tripartite - CIT e aprovados pelo Conselho Nacional de Assistência Social - CNAS.

\section{Pactuação de Metas}

Pactuadas anualmente pela Comissão Intergestores Tripartite - CIT e aprovadas pelo Conselho Nacional de Assistência Social - CNAS.

\section{Forma de repasse e prestação de contas do Programa.}

O recurso será repassado, anualmente, fundo a fundo, de forma automática, em duas parcelas, logo após a adesão do gestor e aprovação do Conselho de Assistência Social do Município e do DF.

A prestação de contas dar-se-á conforme a Portaria MDS n 625/2010, alterada pela Portaria MDS $n^{\circ} 118 / 2011$, ou outras normativas que venham alterá-las.

\section{Avaliação anual}

Para continuação do programa, nos anos seguintes, verificar-se-á o alcance de $10 \%$ da meta pactuada anualmente.

\section{Adesão ao Programa}

Para o recebimento do recurso é necessária a adesão do gestor municipal e do Distrito Federal, por meio do sistema informatizado, disponibilizado pelo MDS, bem como a manifestação do Conselho 


\section{ANEXO B}

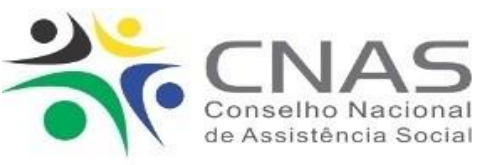

\section{Resolução}

Municipal e do DF de Assistência Social aprovando a adesão do respectivo ente ao Programa Nacional de Promoção do Acesso ao Mundo do Trabalho - ACESSUAS-TRABALHO, que passará a integrar o Plano de Ação, do município ou DF.

\section{Atribuições dos Gestores e dos Conselhos das três esferas:}

- Coordenar nacionalmente o Programa

- Cofinanciar as ações do Programa

- Produzir e divulgar orientações técnicas;

- Apoio técnico, acompanhamento e monitoramento do Programa no Distrito Federal.

- Apoio técnico ao município, principalmente em relação à articulação com diversos setores e políticas;

- Acompanhamento e monitoramento da execução do Programa nos municípios;

- Coordenar o Programa em nível local;

- Executar as ações do Programa, de forma direta ou em parceria com as entidades e organizações de assistência social;

- Acompanhar e monitorar o alcance das metas estabelecidas para o Programa; $\square$ Manter sistema de acompanhamento do programa atualizado.

- Acompanhar, fiscalizar e monitorar a execução do Programa. 